KOÇ UNIVERSITY-TÜSİAD ECONOMIC RESEARCH FORUM

WORKING PAPER SERIES

\title{
KEEPING REFUGEE CHILDREN IN SCHOOL AND OUT OF WORK: EVIDENCE FROM THE WORLD'S LARGEST HUMANITARIAN CASH TRANSFER PROGRAM
}

\author{
Aysun Hızıroğlu Aygün \\ Murat Güray Kirdar \\ Murat Koyuncu \\ Quentin Stoeffler
}

Working Paper No: 2106

June 2021

This Working Paper is issued under the supervision of the ERF Directorate. Any opinions expressed here are those of the author(s) and not those of the Koç University-TÜSİAD Economic Research Forum. It is circulated for discussion and comment purposes and has not been subject to review by referees.

KOÇ UNIVERSITY-TÜSİAD ECONOMIC RESEARCH FORUM

Rumelifeneri Yolu 34450 Sariyer/Istanbul 


\title{
Keeping refugee children in school and out of work: Evidence from the world's largest humanitarian cash transfer program*
}

\author{
Aysun Hizıroğlu Aygün, ${ }^{1}$ Murat Güray Kırdar, ${ }^{+}$ \\ Murat Koyuncu and Quentin Stoeffler ${ }^{\#}$
}

June 24, 2021

\footnotetext{
* We are very grateful to the World Food Programme for providing us access to the CVME and PDM data, and to the World Food Programme and the Turkish Red Crescent, for their respective roles in data collection. We thank the participants of the 2021 Middle East Economic Association Conference, 2021 Society of Labor Economists Conference, and 2021 North American Summer Meeting of the Econometric Society, as well as the Istanbul Technical University seminar participants for useful comments and suggestions. We also thank the WFP staff members-Nils Grede, Berçin Doğan, Çiğdem Çelik, Keeyoul Yoon, İlgi Bozdağ, Meryem Kesgin, Edgar Wabyona-for helpful feedback and suggestions. Our findings do not necessarily represent the views of the WFP or TRC. The usual disclaimer holds.

${ }^{1}$ Istanbul Technical University, Department of Economics, Istanbul 34367, Turkey. e-mail: aysunaygun@itu.edu.tr

' Department of Economics, Boğaziçi University, Bebek, Istanbul 34342, Turkey. e-mail: murat.kirdar@boun.edu.tr. ${ }^{a}$ Department of Economics, Boğaziçi University, Bebek, Istanbul 34342, Turkey. e-mail: mkoyuncu@boun.edu.tr.

\# Istanbul Technical University, Department of Economics, Istanbul 34367, Turkey. e-mail: stoeffler@itu.edu.tr
} 


\begin{abstract}
This paper investigates whether unconditional cash transfers can keep refugee children in school and out of work. We raise this question in the unique context of Turkey, which hosts the world's largest refugee population (including 3.6 million Syrians). Refugees in Turkey are supported by the world's largest cash transfer program for refugees, the Emergency Social Safety Net (ESSN). We exploit a program eligibility criterion to identify the causal impacts of the ESSN program using a regression discontinuity design. The results show a large effect on child labor and school enrollment among both male and female refugee children. Being a beneficiary household reduces the fraction of children working from 14.0 percent to 1.6 percent (a decrease of 88 percent) and the fraction of children aged 6-17 not in school from 36.2 to 13.7 percent (a reduction of 62 percent). By unpacking the mechanisms at play, we show that ESSN cash transfers become a significant part of a household's income, substantially alleviate extreme poverty, and reduce a family's need to resort to harmful coping strategies. Investigating the reasons for children not attending school, we find that the beneficiary households become more likely to send children to school because the cash transfer addresses both the opportunity cost and direct cost of schoolingalthough the former is more important. The findings have important implications for the design of policies aimed at supporting refugee children at scale.
\end{abstract}

Keywords: refugees; cash transfers; education; child labor; regression discontinuity design; program evaluation; Turkey

JEL codes: F22, I21, I28, I38, J21, O15, O22 


\section{Introduction}

Forced displacement is one of the main global priorities for policymakers and the general public, as the number of refugees and internally displaced individuals has increased steadily over the last ten years. There are currently 79.5 million forcibly displaced individuals globally, among whom $40 \%$ are children (UNHCR, 2020a). Although the situation of forcibly displaced individuals worldwide is diverse, ${ }^{1}$ forced displacement generally constitutes a major disruption in the lives of adults and children (Ibáñez and Vélez, 2008; Fiala, 2015). For children in particular, it implies a long-term loss of human capital, as they tend to drop out of school, often permanently, and take up employment at a young age, thus creating the risk of being trapped in poverty in the future (UNICEF, 2014). Although establishing causal relationships is not straightforward (Beegle et al., 2009; Zabaleta, 2011), the adverse effects of working at a young age have been documented in the literature-especially the impact on education. ${ }^{2}$ Yet we have little knowledge regarding the best ways to support refugee children and their households, especially those who live outside refugee camps.

In this study, we investigate whether unconditional cash transfers (UCTs) can lower the incidence of child labor and raise school enrollment among refugee children in Turkey. Turkey hosts the world's largest refugee population, including 3.6 million Syrians, the vast majority of whom do not live in camps. In 2016, this refugee population included 400,000 out-of-school children, who were often working at young age (UNICEF, 2016). In fact, according to the refugee sample of the 2018 Turkish Demographic and Health Survey, 45.1 percent of 15- to 17-year-old Syrian boys had a paid job, and among these, only about 3 percent were enrolled in school (Dayioglu, Kirdar and Koc, 2021). Child labor is also prevalent among Syrian refugees in all neighboring countries, driven primarily by poverty (UNICEF, 2015; Habib et al., 2019; Maadad and Matthews, 2020), but direct and opportunity costs of education factor in as well (de Hoop, Morey and Seidenfeld,

\footnotetext{
${ }^{1}$ Forcibly displaced individuals may live in or outside of camps, be allowed to work or not, have been formally resettled or have fled dire situations, all of which affect child labor and education outcomes.

${ }^{2}$ In contrast, in some very low-income contexts, child work may have a positive effect on human capital accumulation as children learn skills (Dumas, 2012; Machonie and Hilson, 2016). But in a forced displacement setting, where child labor is often a coping strategy to an unanticipated, important shock, and where it often involves heavy, hazardous, or exploitative tasks outside the household, a negative effect of child labor on human capital is expected (Habib et al., 2019).
} 
2019). ${ }^{3}$ The hardships of Syrian refugee children, particularly those resulting from child labor, have been well described (see for example UNICEF, 2015; Küppers and Ruhmann, 2016; Saleh, 2016; UNHCR, 2016). UNICEF (2014) highlights the risk of a "lost generation" as children drop out of school because of forced displacement. Those who drop out permanently are often trapped in poverty in the long run (de Hoop, Morey and Seidenfeld, 2019). ${ }^{4}$

We explore the effect of cash transfers on refugee children's education and employment outcomes by gender in the context of the world's largest cash transfer program that targets refugees, the Emergency Social Safety Net program (ESSN). The ESSN unconditional cash transfer program rolled out in November 2016 in Turkey and had reached 1.8 million refugees as of February 2021. For the average Syrian family in Turkey with 6 members (based on the 2018 Demographic and Health Survey of Turkey), the monthly payment is 720 TL (around USD 105, excluding quarterly top-ups) - which is equal to 55\% of the average monthly labor earnings of Syrian men in Turkey (as estimated by ILO) and 36\% of the average monthly consumption value of the refugee households in the micro-level dataset used in this study. To the best of our knowledge, this study provides, along with a few concurrent working papers, the first evidence of the impact of a largescale cash transfer program on education and child labor of refugee children who live outside camps. We also investigate the mechanisms at play and the heterogeneity of the impact by age group and family background.

Cash transfers affect the optimal allocation of children's time between school, labor market work, home production, and leisure. First, for households that cannot afford the direct schooling costs of some of their children after satisfying their minimum consumption needs, cash transfers make school enrollment a feasible choice for additional children. Second, by increasing household income, cash transfers lower the marginal utility of income obtained from children's market work and home production and thus decrease child labor in both extensive and intensive margins. Given

\footnotetext{
${ }^{3}$ Habib et al. (2019) document the adverse effects of child labor on the health of Syrian children in Lebanon. While these children had little exposure to labor in Syria (4\% child labor rates before the war), they started to work at age 10.9 on average as refugees, often in strenuous and exploitative conditions with consequences on their health.

${ }^{4}$ Keeping refugee children in school is also critical for children because schools provide not only knowledge and skills but also hope, stability, safety and a sense of community (Maadad and Matthews, 2020). Besides, it can eliminate the social and economic inequalities between refugees and host populations which contribute to generating important social conflicts in Turkey and elsewhere (see Saleh, 2016; Erdogan, 2018; Kumar et al., 2018; Hangartner et al., 2019; and De Coninck et al., 2020 for evidence from the media).
} 
the traditional division of labor in the household, a decline in the marginal utility of income obtained from market work would be more important for boys, whereas a fall in the marginal utility of income obtained from home production would matter more for girls - especially among older children.

The effects of cash transfers on refugee children's school and work outcomes might differ from those for native children for a number of reasons. Refugees tend to be poorer than the general population of the host country, so child labor is a more important source of income for them. The cost of schooling is higher for refugees, given the disruption, the material losses and the psychological trauma caused by forced displacement, not to mention the required adaptation to a new education system and the language barrier. On the other hand, the returns on education are likely to be higher than they are for the general population, as schooling provides important skills that ease integration into the host society and the labor market. Therefore, whether the impacts of the policies which support schooling and aim to lessen child labor are as effective for refugees as they are for the native population is ambiguous in theory and needs to be explored empirically.

We draw on data from the Comprehensive Vulnerability Monitoring Exercise (CVME), which is conducted by the World Food Program and is representative of the refugee population in Turkey. Our identification strategy exploits one of the eligibility criteria of the ESSN program. Households with a ratio of dependents to working-age adults of 1.5 or more are eligible for the ESSN program. We use a regression discontinuity design (RDD) to compare households just below and above the 1.5 eligibility criterion. ${ }^{5}$ Being just above the 1.5 cutoff for eligibility does increase the likelihood of receiving transfers by 38 percentage points. We then use a fuzzy-RDD approach to identify the causal effect of being a beneficiary of the transfers. We provide a careful examination of the RDD assumptions as well as several robustness checks of the results. In addition, we utilize a second dataset to provide further evidence of the robustness of our results.

Our results show a large effect of the unconditional cash transfer program on education and child labor among refugee children. It reduces the share of boys not in school from 28.4 percent to 10.4 percent (by 64 percent); the share of girls not in school from 24.9 percent to 10.3 percent (by 59 percent); the share of boys working from 17.0 percent to 2.4 percent (by 86 percent); and the share

\footnotetext{
${ }^{5}$ The fact that the average household size of refugees is quite large helps us in this identification because the number of values that the dependency-ratio (the running variable) takes around the cutoff is reasonably high.
} 
of girls working from 3.3 percent to 0.2 percent (by 95 percent). Decomposing the education results by age, we find that the effect is stronger on children aged 12 to 17 than the effect on children aged 6 to 11 -which is consistent with the opportunity cost of schooling (market work and home production) being higher for older children.

Examining the mechanisms at play, we find that ESSN cash transfers become a significant part of a household's income, substantially reduce extreme poverty, and lower the chances that refugee households engage in costly coping strategies. Hence, they lower the marginal utility of income obtained from children's market work and home production and channel them into education. In fact, analyzing the reasons for children's not attending school, we find that beneficiary households are more likely to send their children to school because the transfers address the opportunity costs of schooling. We also find suggestive evidence that cash transfers increase schooling by addressing the direct costs of schooling.

In terms of impact heterogeneity, we find that the impact on child labor and education decreases in magnitude with an increase in household income and the education level of the household head. In particular, the effect on child labor is much more pronounced among households in the lowest consumption quintile, and the effect on schooling is much stronger for households in the lowest two consumption quintiles. In other words, the beneficial effects of the ESSN program on children's outcomes are most pronounced among the most vulnerable groups.

Overall, our findings imply that major financial constraints among a low-income sample of refugee households — which limit children's school enrollment and drive them into employment — can be alleviated with a modest amount of regular, unconditional cash transfers. From a policy perspective, it is also important to highlight the importance of the existing schooling infrastructure in the materialization of these results. The Turkish education system invested in the integration of refugee children by instituting programs such as language training, pre-educational programs, remedial and back-up courses, teacher training and so forth. It allowed a strong schooling response among refugee children to the ESSN program, as reported above. 
A growing literature exists on the effects of cash transfers to forcibly displaced populations, but few address the effects of cash transfers on schooling and work outcomes among refugee children. ${ }^{6}$ de Hoop, Morey and Seidenfeld (2019) examine the effects of a small-scale program in two governorates in Lebanon where the target population was Syrian refugee children aged 5-14 who were enrolled in a second-shift school. They find an increase in school attendance conditional on school enrollment, but not in enrollment. Our study differs from this study in that it measures the impacts of a larger-scale, multi-year cash transfer program. ${ }^{7}$

A few concurrent working papers also examine the effects of large-scale cash transfers on Syrian refugee households and include a number of schooling and/or work outcomes for refugee children. Ozler et al. (2020) study the ESSN program as well, while Moussa et al. (2021) and Altindag and O’Connell (2020) study much smaller programs in Lebanon. Only Moussa et al. (2021) focus specifically on refugee children. Examining the effect of cash transfers on 6- to 14-year-old Syrian children's schooling and work outcomes in Lebanon, they find a drop in child labor and a transition from informal schooling to formal schooling. Unlike Moussa et al., however, we include an exploration of the mechanisms at play and the impact heterogeneity. ${ }^{8}$ In the context of the same program in Lebanon, Altindag and O'Connell (2020) find that the beneficial effects of the cash transfers on child labor and schooling are concentrated among boys. By contrast, we find that the

\footnotetext{
${ }^{6}$ Many of these studies suggest that cash transfers have positive impacts on the consumption of beneficiaries and hostcountry populations and that they can be more cost effective than alternative delivery mechanisms (Hidrobo et al., 2014; Taylor et al., 2015; Aker, 2017). In a developed country setting, LoPalo (2019) shows that higher cash benefits delivered to refugees lead to better job market outcomes for beneficiaries. With regard to Syrian refugees in neighboring countries, Lehmann \& Masterson (2020) present suggestive evidence that cash transfers to Syrians in Lebanon reduce anti-refugee violence. Valli et al. (2019) also find positive impacts of cash transfers on social cohesion between refugees and host communities in Ecuador.

${ }^{7}$ A number of impact evaluation reports have been commissioned by international NGOs on the impacts of unconditional cash transfer programs for refugees; however, these are all in the context of Lebanon and Jordan. These reports - in the context of Syrian refugees in Jordan (Gaunt, 2016 and Giardano et al., 2017) and in Lebanon (Battistin, 2016; Foster, 2015; Lehmann and Masterson, 2014)—present mixed findings about the subject: Battistin (2016) finds no evidence of a beneficial impact on children's schooling or work outcomes; Gaunt (2016) measures very small effects on school enrollment and child labor; and Foster (2016), Giardano et al. (2017) and Lehmann and Masterson (2014) report improvements in school enrollment and attendance among the beneficiaries.

${ }^{8}$ There are also differences in program designs: in Lebanon, beneficiary households receive the multi-purpose cash transfer for 12 months and are re-evaluated each year, with the possibility of losing their eligibility (as the number of beneficiaries is fixed). ESSN beneficiary households, however, can receive transfers indefinitely unless certain changes in their family composition occur (note that such events are low probability).
} 
ESSN program has an effect on both boys' and girls' school enrollment and employment. In a concurrent work that is closely related to our study, Ozler et al. (2020) measure the effect of the ESSN program on refugee children's school enrollment, but not employment. While their study reports no evidence of a policy effect on children's school enrollment, we find a substantial impact. ${ }^{9}$

Finally, this study also contributes to the general literature on the effects of UCTs on child labor and schooling. ${ }^{10}$ While the impacts of conditional cash transfers (CCTs) on child labor and schooling have been frequently studied, ${ }^{11}$ evidence on UCTs is more scarce and the evidence is mixed (Baird et al., 2014; Baird et al., 2011; Akresh et al., 2013). In addition, the findings related to the impact of UCTs on child labor are mixed and context-specific, as transfers can induce large decreases or instead increases in child labor (Edmonds, 2006; Edmonds and Schady, 2012; de Hoop, Friedman et al., 2019; de Hoop, Groppo and Handa, 2019). We find that the UCT we examine substantially increases schooling while decreasing child labor. ${ }^{12}$

The rest of the article is structured as follows. The next section describes the context and the program. Section 3 presents the data, and Section 4 explains our identification method and estimation. Results are given in Section 5. Section 6 provides additional robustness checks, and Section 7 concludes.

\footnotetext{
${ }^{9}$ Several important differences should be noted. First, Ozler et al. (2020) use a different dataset (which we use for robustness checks); theirs has a panel structure but fewer outcome variables. Second, we examine a wider range of outcome variables, including child labor. Third, and most importantly, while they use an identification method that is based on selection on observables (inverse probability weighting), we use RDD, which handles selection on unobservables. Fourth, we address the relative importance of the roles played by opportunity costs and direct costs of schooling in refugee children's school non-enrollment. Fifth, we examine heterogeneity in estimated effects by income and several other background characteristics.

${ }^{10}$ The problem of child labor is an important policy issue, obviously not limited to forcibly displaced populations (Grootaert and Kanbur, 1995; Basu, 1999). While progress in combatting child labor has been made worldwide since the 2000s, there are still 152 million children aged 5 to 17 in child labor (ILO, 2017). Among these, 64 million are girls and 88 million are boys. A majority of these children live in middle-income countries, and $48 \%$ are between 5 and 11 years old. These figures exclude children who are working legally.

${ }^{11}$ See for instance Attanasio et al. (2010), Galiani and McEwan (2013), De Janvry et al. (2006), Dammert (2009), del Carpio et al. (2016), and Ravallion and Wodon (2000).

${ }^{12}$ Some studies find that cash transfers increase child labor due to productive investments that families can make using the transfers. In our context of refugees in a middle-income country where most of them live in urban areas, this does not seem to be an important phenomenon.
} 


\section{Refugees in Turkey and the ESSN program}

\subsection{Syrian Refugees in Turkey}

Since its onset in 2011, the Syrian conflict has led to a massive outflow of refugees-over 5.5 million as of mid-December 2020. Turkey, as Syria's largest neighboring country and one in close proximity to the conflict areas, received $65 \%$ of the Syrian refugees (3.6 million), almost half of whom are children (UNHCR, 2020b). As of the same date, only 1.6 percent of Syrian refugees in Turkey live in camps; the rest are scattered across the country, living among the host community in urban areas. Even though the borders were closed occasionally and more tightly controlled after 2015, Turkey has generally adopted an open-door policy towards Syrian refugees. As a result, the number of refugees increased steadily between 2013 and 2017 (Figure A1 in Appendix A). ${ }^{13}$

While the influx of Syrian refugees was initially considered an emergency crisis, Turkey's institutional framework has evolved towards a longer-term management of its refugee population. Initially, the Disaster and Emergency Management Authority (AFAD), a governmental body responsible for coordinating humanitarian aid and emergency response at the national level, was in charge of registering the refugees and organizing refugee camps. In 2014, the Turkish government enacted a framework referred to as the Temporary Protection Regime for the Syrian refugees, which defined their rights to access to public health, public education, and social protection. A Directorate General for Migration Management (DGMM) was established and tasked with registering refugees and the overall coordination of policies regarding refugees. At the end of 2015, the EU and Turkey signed an agreement on the funding and the handling of the refugee crisis, which would eventually lead to the establishment of the ESSN program with funding from the EU (WFP, 2018).

\footnotetext{
${ }^{13}$ Even though Syrians in Turkey are not officially granted refugee status by the Turkish Government, they are referred to as "refugees" in this paper for simplicity. According to the Turkish Law on Foreigners and International Protection, their legal status is designated as "under international protection/temporary protection" or as "having a humanitarian residence permit."
} 
A comparison of demographic characteristics of Syrian refugees and natives reveals that refugees tend to live in larger households and are younger and less educated than the natives. ${ }^{14}$ The Syrian and Turkish samples of the 2018 Demographic and Health Survey of Turkey (TDHS) indicate that the average household size of Syrian families is 6 , versus 3.5 for Turkish families. Syrian refugees are also poorer: according to the Pre-Assistance Baseline (PAB) survey conducted prior to the launch of ESSN, 28.6 percent of Syrian refugees that resided outside camps were food insecure, and 93 percent were below the national poverty line (WFP, 2016).

Syrian refugees have had little access to formal employment. Until January 2016, they were not allowed to work formally, except in special circumstances; in fact, only 7,351 work permits had been issued for Syrians by then (Ministry of Family, Labor and Social Services [MoFLSS], 2019). In January 2016, refugees under Temporary Protection became eligible to hold work permits (Law no. 8375). However, the conditions attached to work permits severely limited the effectiveness of the new regulation (Memişoğlu, 2018). In 2018, the number of work permits issued to Syrians was still only 34,573 (MoFLSS, 2019). The vast majority of Syrian refugees therefore work informally (without social security coverage) to satisfy their basic needs. No official statistics are available for the labor market outcomes of Syrian refugees, but Pinedo-Caro (2020) estimates that 813,000 Syrians were employed in 2017, which implies that 97 percent of them worked informally. ${ }^{15}$ Although the majority of Syrian men work long hours (76 percent of Syrians worked more than 45 hours per week, the legal maximum number of working hours in Turkey (Pinedo-Caro, 2020), they earned 1,300 TL per month on average in 2017, which is 7 percent below the minimum wage of 1,400 TL (Pinedo-Caro, 2020). ${ }^{16}$

\footnotetext{
${ }^{14}$ The share of members below age 15 is $45 \%$ in Syrian and $25 \%$ in Turkish households. The median number of years of education of Syrian women (4.5 years) and men (5.1 years) is lower than the median for native women (4.8 years) and men (7.1 years) (Hacettepe University Institute of Population Studies, 2019a, 2019b).

${ }^{15}$ Pinedo-Caro (2020) also reports a 47 percent employment rate among Syrian refugees, which is in line with surveys reviewed by Aksu et al. (2018). Many studies report that refugees mostly work as unskilled workers in construction, agriculture, and textile and clothing manufacturing (Erdoğan, 2014; Ferris and Kirisci, 2016; Karadeniz, 2018; PinedoCaro, 2020). In fact, Aksu et al. (2018) find a significant level of displacement of natives working informally in these sectors.

${ }^{16}$ Other sources document even lower wage levels: a survey conducted by IOM (2018) in four southeastern provinces with dense refugee populations indicates that refugees earned 908 TL per month on average in 2017 and that 70 percent of households had to resort to borrowing to meet their basic needs.
} 
While access to the formal labor market remained severely constrained for refugees, refugee children benefitted from a relatively easy and free access to the Turkish education system. The Turkish Ministry of National Education (MoNE) released a circular in 2014 which reduced the administrative barriers to public school enrollment for Syrian children (İçduygu and Şimşek, 2016). As the once-temporary situation of Syrian refugees gained permanence, further steps were taken to increase the enrollment of Syrian children in public schools after 2016 (ERG, 2018). These steps included increasing the supply of intensive Turkish language training programs for refugee children and gradually shutting down temporary education centers (TECs), which had been providing education in Arabic in line with a modified version of the Syrian curriculum (Ombudsman Institution of the Republic of Turkey, 2018).

The MoNE data in Table A1 in Appendix A show that, while the enrollment rate of 5- to 17-yearold Syrian children (including pre-school) was only 30 percent in the 2015-2016 school year, this figure increased to 37 percent in the 2016-2017 school year and to 59 percent in 2017-2018; in subsequent school years, it leveled off in the range of 61-64 percent and has remained there. Enrollment rates vary significantly by grade level; for instance, in the 2017-2018 school year, the enrollment rate was 97 percent at primary level, but only 58 percent at secondary level, 26 percent at high-school level, and 33 percent at pre-school level. Attendance rates, however, appear to be much lower than official enrollment rates that were recorded at the start of the school year (Hacettepe University Institute of Population Studies, 2019b).

Several reports indicate that financial constraints played an important role in the low demand for education among refugee households - in addition to the supply side constraints such as overcrowding in schools in refugee-dense neighborhoods and language barriers. Both UNHCR (2017) and IOM (2017) document the fact that families often prioritize basic needs over educational expenses and have to send their children to work in order to increase family income. ${ }^{17}$ In fact, Kirdar et al. (2021) find a high correlation between refugee boys' entry into employment and dropping out from school after age 12. In addition, UN Women (2018) suggests that child marriage may be related to low enrollment rates of girls at the high school level.

\footnotetext{
${ }^{17}$ In addition, although public schools in Turkey are free, families need to pay some out-of-pocket costs for supplies, uniforms, school lunch, and transportation when they send children to school.
} 
Based on the 2018 Turkish Demographic and Health Survey's Syrian refugee sample, which is representative of the refugee population in Turkey, Dayioglu, Kirdar, and Koc (2021) report a remarkably high incidence of paid work among Syrian boys: 45.1 percent of 15- to 17-year-old Syrian boys and 17.4 percent of 12- to 14-year-old Syrian boys have a paid job. The numbers for girls in the same age groups are much lower, at 8.1 and 4.7 percent, respectively. They also show that less than 3 percent of refugee children in paid work are enrolled in school. By contrast, 9.5 percent of 15- to 17-year-old native boys and about 60 percent of adult refugee men aged 18 to 59 have paid jobs.

\subsection{The ESSN program}

The ESSN program is an unconditional cash transfer scheme providing monthly assistance to over 1.8 million refugees in Turkey as of February 2021 (IFRC, 2021). Implemented nationwide in November 2016, it has become the world's largest cash transfer program that targets refugees. ${ }^{18}$ It is funded by the European Union, under the Facility for Refugees in Turkey (FRiT). It is currently implemented by the Turkish Red Crescent in collaboration with the IFRC and the Ministry of Family, Labor and Social Services of Turkey. The World Food Programme (WFP) was responsible for facilitating the design, implementation, monitoring and evaluation of the first two phases of the ESSN until April 2020. One of the main objectives of the program is to "reduce or stabilize families' use of coping strategies such as sending children to work instead of school" (WFP, 2019a). ESSN is not limited to Syrians - it is offered to refugees from other countries as well. ${ }^{19}$

To apply for ESSN benefits, refugees must first be registered with the DGMM and have a residence address on file with the local Civil Registry Office. ${ }^{20}$ Households are then eligible for ESSN if

\footnotetext{
${ }^{18}$ Total aid dispersed under ESSN amounted to 1.1 billion Euros by the end of 2020, while the monthly payments were around 24 million Euros. Aid programs targeting Syrian refugees existed even before the ESSN program. Since 2011, AFAD and the Turkish Red Crescent (TRC) have provided aid to Syrian refugees in collaboration with local and international NGOs. While most assistance occurred in an irregular fashion, the WFP and TRC's joint e-food voucher program provided a consistent means of livelihood to refugees living in camps, as each individual received 100 TL per month. Launched in a single refugee camp in 2012, the program was expanded to a total of 21 camps in 2014 , and covered up to 150,000 of the refugees in the camps at its peak (WFP, 2016). These programs were therefore substantially smaller than ESSN, both in terms of the amount of cash provided and the number of beneficiaries.

${ }^{19}$ Turkey also hosts more than 370,000 refugees mainly from Afghanistan, Iraq, Iran, and Somali.

${ }^{20}$ Those employed with a valid work permit or who own registered assets in Turkey are not eligible to receive assistance.
} 
they satisfy one of six demographic criteria: (1) a dependency ratio greater than or equal to 1.5 (essentially, at least three dependents for every two able-bodied adults aged 18-59); (2) families with four or more children; (3) single females; (4) elderly-headed households; (5) single-parent households; and (6) households with one member who has an officially documented disability of at least 40 percent. These criteria were selected as proxy measures of inability to meet basic needs, as they were considered to correlate well with household poverty and vulnerability for a program which necessitates simple and transparent inclusion rules (TRC, 2020; Cuevas et al., 2019). Refugees can apply for the cash assistance through TRC Service Centers or Social Assistance and Solidarity Foundation offices.

ESSN beneficiary households receive 120 TL per month for each member. For the average sixmember Syrian family in Turkey, this amounts to $720 \mathrm{TL}$ per month. The program also provides additional quarterly top-ups ranging from 100 TL to 600 TL per person (depending on household size) to help cover large expenses such as housing rents. Households with members who require specialized care also receive a special monthly payment of 600 TL. Cash transfer amounts are sizeable in comparison to refugees' monthly labor earnings. Not counting special payments, the monthly ESSN transfers for a family of six (720TL) amount to 55\% of the average monthly labor earnings of Syrian men and 43\% of the monthly minimum wage rate in Turkey in 2017 (see subsection 2.1). ${ }^{21}$ The transfer payments are loaded onto debit cards provided to the beneficiaries, who can either withdraw the installed cash from ATMs or use the card to make purchases.

\subsection{Other Programs Targeting the Education of Refugee Children}

Here, we introduce educational programs that target refugee children in Turkey that either preceded or operate simultaneously with the ESSN program. (We discuss in Section 4 how these other programs might affect our identification of the effect of the ESSN program or interact with the ESSN program.) A variety of educational programs have been developed that address the pressing issues of the refugee population both within the framework of FRiT and separately via collaborations between international NGOs and the Turkish government. These include early

\footnotetext{
${ }^{21}$ Cuevas et al. (2019) report that, according to the PAB data, this amount covers $51 \%$ of the per capita spending of the eligible households, but they also mention that the expenditures in this survey are likely to be underestimated. In our dataset, which is representative of the refugee population in Turkey, the same figure is $30 \%$. ESSN transfer payments are not adjusted for inflation, so the purchasing power of the transfer income has decreased over time.
} 
childhood education programs, Turkish language training, classes taught in Arabic, catch-up and remedial classes to address learning performance issues, school construction and refurbishment, conditional cash transfers, textbook and transportation support, and teacher training.

A program called Promoting Integration of Syrian Children into the Turkish Education System (PICTES) comprises several of these interventions and is notably large in scale (Arık Akyuz et al., 2018). PICTES was considered the flagship education program of the FRiT framework, with a budget of 300 million Euros for the period 2016-2018 and boasts a broad range of interventions. In 2019, for example, 382,519 Syrian children received Turkish language training in addition to several additional forms of support. ${ }^{22}$ These interventions address some of the barriers to participation in the Turkish education system and are complementary to ESSN.

Also contributing to the integration of refugee children into the education system in Turkey is the Conditional Cash Transfer for Education (CCTE) program. The CCTE program is, in essence, a national social assistance program that aims to encourage school enrollment and improve attendance of native children. Launched in 2003, it was extended to refugee families in May 2017 thanks to a collaboration between the MoFLSS and UNICEF. The program reached about 376,000 refugee children by November 2018 (TRC, 2018). Households receive 45-75 TL per month, paid bi-monthly, for each child who is attending school at least $80 \%$ of the time. The amount depends on their gender and grade. These amounts are smaller than ESSN benefits, but they are available to all refugee households.

\section{Data}

\subsection{CVME Survey}

Our main analysis of the effects of cash transfers on child labor and schooling outcomes is based on the Comprehensive Vulnerability Monitoring Exercise (CVME). The CVME surveys offer a number of advantages for measuring education and child labor. It was conducted by the

\footnotetext{
${ }^{22}$ In total, 4,923 Syrian children received education in Arabic, 37,153 Turkish and Syrian kids were supported in early childhood education, 9,423 out-of-school kids had remedial courses, 18,658 children had back-up courses, 81,300 Syrian and Turkish children received transport support, and 28,522 children received school supplies. Also, 413 guidance counselors were employed to provide psychosocial support to 127,921 children, and nearly 2,000 teachers and administrative personnel received training (MoNE Directorate of Lifetime Learning, 2020b).
} 
Vulnerability Analysis and Mapping (VAM/MandE) unit of the World Food Program in Turkey with the aim of assessing the vulnerability of refugees (WFP, 2019b) ${ }^{23}$ Issues addressed in the survey include the demographic composition of households, arrival profile, housing, income sources, consumption expenditures, food security and coping mechanisms, and health and special needs. Importantly, the CVME datasets we use include information about work and the schooling of children aged 6 to 17, disaggregated by gender.

We pool data from the third (CVME3) and the fourth waves (CVME4), which are cross-sectional surveys. Each of these two waves is representative of the refugee population in Turkey (for more information about the sampling strategy, see WFP, 2019b). CVME3 and CVME4 were administered to 1,301 and 1,380 households, respectively. The survey sample includes ESSN beneficiary households, non-beneficiary applicants, and households that did not apply for ESSN benefits. The CVME3 data were collected between March and August 2018, while the CVME4 data collection was carried out between September and December 2018. The data were collected in face-to-face interviews by WFP staff with support from the TRC.

We use information about the employment and schooling of children as the main outcome variables in our analysis. Specifically, we use the number of children (defined as below age 18) who had worked in the past 30 days, and the number of children (aged 6-17) who were not enrolled in school the previous semester and did not plan to return. Based on the total number of children in the household, we also generate the share of children working and the share of children not enrolled in school. These shares are set to zero in households with no children. We also create dummy variables for having any child working and having any child not enrolled in school. All of these variables are generated by gender.

We further analyze ESSN's effectiveness in overcoming the main barriers to education by using information on reasons for not being enrolled in school as outcome variables. In the survey, these reasons are listed as "children need to work," "children need to stay at home and assist the family in household chores," "family cannot afford to pay the explicit costs of schooling," and "children are sick." Survey participants were allowed to report multiple reasons where applicable. We create

\footnotetext{
${ }^{23}$ The WFP received support from the Turkish Red Crescent (TRC) for the implementation of its surveys among refugees in Turkey.
} 
dummy variables for each of these reasons. When the family does not have a school-aged child or when all of their children are enrolled in school, these dummy variables take the value of zero.

Taking advantage of the richness of the CVME survey, we also explore outcomes related to income sources, poverty, housing and assets, consumption, food security, coping mechanisms, and health in order to better understand the mechanisms at play. Income sources refers to the main sources of income that sustained the household in the previous 30 days. Using this information, we generate dummy variables for the following: (i) a household reports WFP/TRC assistance as the main source of income and (ii) a household reports WFP/TRC assistance as a secondary or third income source. We also calculate household per capita consumption. ${ }^{24}$

We employ two poverty lines for defining households in poverty and in extreme poverty. For the poverty line, we use the World Bank upper-middle-income country threshold of 5.5 USD PPP per capita per day (or 4,453 TL per year). For the extreme poverty line, we use a threshold which corresponds to the consumption level of the first quintile of consumption in the CVME3 $(2,779$ TL). ${ }^{25}$ We calculate the poverty headcount, the poverty gap, and squared poverty gap variables that correspond to each poverty line (Foster et al., 1984). We also generate a housing index variable based on the household housing characteristics. ${ }^{26}$ In addition, we measure the total number of household assets (up to 18 items) such as mattresses, winter clothes, and household appliances.

CVME surveys were designed to compute several common indicators of food security (Wiesmann et al., 2009; Vaitla et al., 2015). The Food Consumption Score (FCS) is an indicator based on the frequency of various food items consumed in the previous 7 days. ${ }^{27} \mathrm{We}$ also generate the reduced

\footnotetext{
${ }^{24}$ Consumption categories in the dataset include food and non-food items, as well as other types of expenses made in the previous 7 days, 30 days or 6 months. We use a CPI deflator to take into account price differences across regions and censor at the 99th percentile for our main analyses. (Values above the 99th percentile are set equal to the 99th percentile). Since we do not observe children's ages in CVME3, adult equivalent consumption cannot be calculated.

${ }^{25}$ We use the consumption of the first quintile in CVME3 rather than the international poverty line of 1.9 USD PPP because only 25 households in CVME3 have consumption below 1.9 USD PPP. The results using the 1.9 USD PPP poverty line are robust and available upon request.

${ }^{26}$ These housing characteristics are the number of rooms per household member (set as 1 when the ratio is greater than 1); having an inside-toilet; having a separate kitchen; using gas for cooking; having electricity; having garbage collected by the municipality; and having sufficient water, hygiene items, and fuel. The index simply adds up the values of indicator variables for these items.

${ }^{27}$ In fact, the FCS is a weighted sum across 8 food categories of the number of days a category of food was consumed in the last 7 days. The exact formula used is: $\mathrm{FCS}=($ starches*2 $)+($ pulses*3) $)(($ vegetables + fruit $) * 1)+($ meat $* 4)+$
} 
Coping Strategy Index (rCSI) variable based on the WFP definition. The rCSI is an index that reflects the frequency of certain types of harmful coping behaviors in the previous 7 days when a family lacks food. ${ }^{28}$ In addition, the Livelihood Coping Strategy index aggregates 13 harmful behaviors related to income and livelihood to cope with insufficient money for meeting basic needs in the previous 30 days. ${ }^{29}$ Finally, we analyze the number of sick children, and the number of sick children for whom treatment was sought in the previous 30 days.

As control variables, we use information about household head characteristics, household composition, the date of arrival in Turkey, and the region where the household resides. The characteristics of the household head that we use include nationality (Afghan, Iraqi, Syrian, and other), gender, education (illiterate, literate, primary school, middle or high school, university, and missing), and occupation before arrival (management/highly skilled such as engineers, doctors, teachers; skilled such as shop managers, technicians, and semi-skilled such as bus drivers, secretaries; unskilled such as agricultural worker, domestic work; retired; other). The measures we use for household composition are the number of children below age six, the number of children aged 6 to 17, and household size. We also use information about the date of the first household member's arrival in Turkey. Finally, we control for the place of residence, using indicators for the 12 NUTS-1 regions of Turkey.

We also generate a dummy variable for a household's eligibility to receive ESSN transfers based on criteria other than the dependency ratio. For this purpose, we use information on household composition to check whether households satisfy any of the five other criteria and whether

\footnotetext{
$($ dairy*4) $+\quad($ fats*0.5) $\quad+\quad$ (sugar*0.5). See $\quad$ WFP's $\quad$ documentation: https://documents.wfp.org/stellent/groups/public/documents/manual_guide_proced/wfp271745.pdf?.ga=2.3190278 2.1884474012.1599390561-891451462.1599390561

${ }^{28}$ These are: relying on less preferred, less expensive food; reducing the portion size of the meals; reducing the number of meals eaten per day; restricting consumption by adults so that children can eat; and borrowing food or relying on help from others. See manual for details: https://documents.wfp.org/stellent/groups/public/documents/manual_guide_proced/wfp211058.pdf

${ }^{29}$ These coping strategies include, for instance, selling household goods; borrowing money; reducing essential nonfood expenditures such as education or health, marriage of children under age 16; begging; accepting high risk or illegal, exploitative temporary jobs; and sending an adult member back to Syria to seek work.
} 
household members are registered with the administration (see Section 2). ${ }^{30}$ This eligibility variable is used as an additional control variable.

\subsection{Descriptive Statistics}

Table 1 provides descriptive statistics for the 2,681 households in our sample. Among these households, 51.6 percent receive ESSN transfers. In the sample, $8.4 \%$ of the boys and $1.8 \%$ of the girls below age 18 had worked in the previous 30 days. In addition, 18.8\% of the boys and 16.6\% of the girls aged 6-17 were not enrolled in school during the previous semester. These statistics reveal that child labor among the refugees is more common for boys than for girls, while school non-enrollment is similar for girls and boys.

Table 1 also includes descriptive statistics for the secondary outcome variables, which we study as mechanisms. The WFP assistance is a crucial source of income for beneficiaries, with 39\% of the households listing the WFP assistance as the main income source in the last 30 days and 21\% listing it as the second or third income source. However, living standards are low in our sample. The average annual per capita consumption is 4,900TL, approximatively half of which is devoted to food consumption. Based on the upper-middle-income country poverty line, 53\% of the households in our sample are poor, with an average poverty gap of 0.15 .

In terms of food security, the average FCS for most of the households in our sample is 78, which indicates acceptable levels of food security. Only 5.5 percent of the households in the sample have an FCS below 42, which is commonly used as the threshold of "borderline" food security (Wiesmann et al., 2009). The average rCSI in the sample, however, is 13.4; the scores range from 0 to 56 (the highest score possible, indicating high food insecurity). In addition, 28 percent of households in the sample have an rCSI above 18, indicating relatively high levels of food insecurity. This suggests that households are under severe stress in terms of food security. The average Livelihood Coping Strategies index in our sample is 1.7 , with scores ranging from 0 to 9 ,

\footnotetext{
${ }^{30}$ The family composition that makes a household eligible via any of the other 5 criteria implies a minimum number of household members. For instance, a household that satisfies the single-parent criterion must have one adult and at least one child - implying that the household size is at least two. In this case, we check that at least two household members are registered with the Civil Registry and DGMM.
} 
which means that, on average, households have used more than one harmful coping strategy in the previous 30 days.

Finally, Table 1 shows the fraction of children not going to school for each of the stated reasons for non-enrollment. (Note that these are sample averages; i.e., they are not conditional on having children not going to school). At least one child does not go to school in $10 \%$ of the households because they needs to work, and in 3\% of the households because they needs to stay home to assist their family. In $4 \%$ of the households, one child does not go to school because the family cannot afford school expenses. In sum, child labor is the primary reason for school non-enrollment.

Descriptive statistics for our control variables are given in Table A2 in Appendix A. For 72\% of the sample, the head of the household is a Syrian national, 19\% are Iraqis, $8 \%$ are Afghans, and the remaining $1 \%$ are other nationalities. A majority of refugees $(58 \%)$ moved to Turkey more than 3 years prior, and $30 \%$ arrived 1 to 3 prior. Only a small share of the household heads (7\%) hold a university degree, while $29 \%$ had completed middle or high school and $31 \%$ had completed primary school; $21 \%$ are illiterate. A great majority of the household heads $(75 \%)$ worked in an unskilled job before arriving in Turkey, with only 16\% having worked in skilled jobs or in management or high skilled occupations. Female-headed households constitute $18 \%$ of the sample. The average household size is 5.9, including 1.3 children below age 6 and 1.9 school-aged children (aged 6 to 17).

In terms of ESSN eligibility criteria, households that satisfy the single women criteria constitute only $0.5 \%$ of the dataset. Elderly households with no other adult are $1.2 \%$ of the sample, and single parents with at least one child and no other adult compose $4 \%$ of the sample. Thirteen percent of the households have at least one disabled member with an official health report, and $37 \%$ have at least 4 registered children. Forty-eight percent of the refugees in our sample meet at least one of these five eligibility criteria. On the other hand, $49 \%$ of the sample meets the dependent ratio eligibility criteria alone, making it the most commonly met criteria in the sample. Our identification strategy described in the next section exploits the dependent ratio eligibility criteria in an RDD. 


\section{Identification Method and Estimation}

To identify the effect of receiving cash transfers, we exploit the dependency-ratio cutoff in a regression discontinuity design. ${ }^{31}$ As explained earlier, one of the eligibility criteria for households for receiving ESSN benefits is to have a dependency ratio above 1.5. Hence, we expect a jump in the beneficiary status at this cutoff value as well as a jump in child employment and schooling outcomes. In the estimation of these reduced-form effects of the dependency-ratio criterion, we use the following sharp RDD specification,

$$
y_{i}=\beta_{0}+\beta_{1} T_{i}+I\left(T_{i}=0\right) f\left(x_{i}^{i}\right)+I\left(T_{i}=1\right) g\left(x_{i}^{i}\right)+X_{i} \Gamma+u_{i}
$$

where $y_{i}$ denotes the outcome variable for household $i$. The treatment variable, $T$, takes the value of one when the dependency ratio is 1.5 and above, and zero otherwise. The indicator function, $I($.$) , takes the value of one when the statement inside the parentheses is true and zero otherwise.$ The functions $f($.$) and g($.$) stand for the trend in the outcome variable on the left- and right-hand$ sides of the cutoff, respectively. In equation (1), $X$ stands for the set of control variables and $u$ for the error term. The control variables include (i) a set of variables for household composition and household head characteristics and (ii) two dummy variables - one for the survey wave and another for the ESSN eligibility status via any of the five criteria other than the dependency ratio. The elements of these sets of variables have already been described in the Data Section. In equation (1), $\beta_{1}$ gives the reduced-form effect of the dependency-ratio eligibility criterion on the outcome variable. The standard errors are clustered at the dependency-ratio level.

We also measure the effect of being a beneficiary on children's schooling and employment outcomes. Some households with a dependency ratio below 1.5 are beneficiaries (because they meet other criteria), and not all households on the right-hand side of the cutoff receive cash transfers. Therefore, we use a fuzzy RDD to measure the effect of being a beneficiary, based on the jump in the probability of being a beneficiary observed at the dependency-ratio cutoff. The estimation of the fuzzy RDD is carried out using a 2SLS procedure, as follows:

$$
D_{i}=\alpha_{0}+\alpha_{1} T_{i}+I\left(T_{i}=0\right) k\left(x_{i}^{i}\right)+I\left(T_{i}=1\right) l\left(x_{i}^{i}\right)+X_{i} \Delta+u_{i}
$$

\footnotetext{
${ }^{31}$ This main identification strategy is applied to the CVME datasets, and as a robustness check, to the PDM dataset, as described in section 5 .
} 


$$
y_{i}=\gamma_{0}+\gamma_{1} \widehat{D}_{i}+I\left(T_{i}=0\right) m\left(x_{i}^{i}\right)+I\left(T_{i}=1\right) n\left(x_{i}^{i}\right)+X_{i} \Theta+v_{i} .
$$

Equation (2) illustrates the first stage, where the dummy variable for the status of receiving cash transfers $\left(D_{i}\right)$ is regressed on the same set of variables as in equation (1). The second stage, given in equation (3), has the same structure as equation (1) - except that the predicted treatment status from equation (2), $\widehat{D}_{i}$, replaces the assignment to the treatment $(T)$.

Hahn et al. (2001) show that, under certain assumptions, the fuzzy RDD identifies the LATE at the cutoff. Hence, the assumptions of the LATE theorem (Imbens and Angrist, 1994) apply to the fuzzy RDD as well. The key assumption here is the exclusion restriction assumption-which requires that the treatment (the dependency ratio being higher than 1.5) have no direct effect on the outcomes other than through its effect on the beneficiary status, conditional on the covariates in the specification. The dependency ratio might have a direct effect on children's schooling and employment outcomes due to its correlation with household structure, but we use a rich set of control variables on household composition (household size, number of children below age 6 and school-aged children) in our specification. Another assumption of the LATE theorem is monotonicity, which requires that the treatment affect all households in the same direction in terms of the probability of receiving the treatment. There is no reason to think that exceeding the dependency ratio threshold would cause certain households not to receive the treatment.

A key issue in identifying the policy effect is the correct specification of functional forms for trends on both sides of the cutoff. We use both parametric and nonparametric methods, which take different approaches in the tradeoff between bias and precision. Nonparametric methods, which typically use narrow bandwidths around the cutoff, are relatively less precise. Parametric methods, on the other hand, use more observations in larger bandwidths and provide more precision, but they carry a risk of larger biases due to functional form misspecification. We see these methods as complementary; in fact, Lee and Lemieux (2010) argue that "[n]onparametric estimation does not represent a 'solution' to functional form issues raised by RD designs. It is therefore helpful to view it as a complement to — rather than a substitute for-parametric estimation."

In our analysis with a parametric approach, we start with the full data and gradually zoom in around the cutoff by narrowing the bandwidth to assess the robustness of our findings. In the order of narrowing bandwidths, we take a dependency ratio between zero and 4.5 (bandwidth equal to 1.5 on the left-hand side of the cutoff and 3.0 on the right-hand side), between zero and 3 (bandwidth 
equal to 1.5 on both sides), and between 0.5 and 2.5 (bandwidth equal to 1 on both sides). In all cases, we take split linear polynomials on both sides of the cutoff.

In terms of non-parametric approaches, we use two different bandwidth selection approaches: the methods of Imbens and Kalyanamaran (2012, IK) and of Calonico, Cattaneo, and Titiunik (2014, CCT). When we use IK optimal bandwidths (b), we also assess the robustness of our findings with alternative bandwidths with $b / 2,3 b / 2$, and $2 b$. When we use CCT optimal bandwidths, we examine robustness using both their bias-corrected and robust standard errors, as well as alternative methods of calculating the optimal bandwidth offered by their approach. In both approaches, we also check the robustness of our findings to the use of alternative kernels.

\subsection{Checks of the Identification Assumption}

The key identification assumption is that the outcome variables are smooth in the running variable around the cutoff. While this is not directly testable, three tests are commonly used to assess the plausibility of this assumption: (i) continuity of the score density around the cutoff, (ii) absence of treatment effects on pretreatment covariates, (iii) absence of treatment effects at artificial cutoff values.

Continuity of the score density around the cutoff requires that households must not have manipulated the running variable in order to be eligible for the program. In such cases of manipulation, we would expect a higher mass on the immediate right-hand side of the cutoff. To examine this possibility, Figure B1 in Appendix B provides a histogram of the dependency-ratio variable. As expected, peaks exist at every half value of the dependency ratio-for example, 0.5, 1.0, 1.5 and so forth - due to the structure of this variable. At the same time, the peak at 1.5 is not more pronounced than the other peaks. To examine potential manipulation more formally, we use the test developed by Cattaneo, Jansson and Ma (2018), which compares the density of observations on each side of the cutoff. The results are displayed in Figure B2 in Appendix B. The null hypothesis that no difference exists in the density of treatment and control groups at the cutoff is rejected at the cutoff value of 1.5, but it is also rejected at 1.0, 2.0, and 2.5. In fact, the test statistic at the actual cutoff value of 1.5 is smaller than the test statistics at the cutoff values of 1.0 and 2.5-indicating the absence of a disproportionately higher peak at 1.5. Essentially, this analysis provides no obvious evidence for manipulation of the running variable, although it is 
certainly difficult to reach sharp conclusions on manipulation from this analysis due to the structure of the variable.

Hence, in panel (2) of Figure B2, we exclude the observations where the dependency ratio takes the value of 1.5, and we conduct the Cattaneo-Jansson-Ma test with two alternative bandwidths: (i) bandwidth $=0.5$ in panel (A) and (ii) bandwidth $=1.0$ in panel (B). In this case, we fail to reject the null in both cases. Therefore, no evidence of manipulation of the running variable exists once we exclude the peak at the actual cutoff. In a parallel manner, in certain robustness checks on our estimation results, we exclude the cutoff point and other alternative bandwidths in the immediate neighborhood of the cutoff (creating so-called "donut-holes").

Next, we examine the policy effect on pre-treatment covariates at the cutoff. In the absence of sorting around the cutoff, no jump would be observed at the cutoff for the pretreatment covariates. Table B1 in Appendix B shows that evidence for a jump that is statistically significant at the 10percent level exists only for 4 of the 38 covariates - which is expected, given the statistical level. At the 5-percent level, no evidence of a jump is observed for any covariate.

Finally, we examine the potential effect of the policy at artificial cutoff values. For this purpose, we take two samples: one that is restricted to the left-hand side of the cutoff and one to the righthand side. Within each sample, we take alternative cutoff values (while keeping the sample size on each side of the artificial cutoff large enough). With the sample restricted to the left-hand side of the actual cutoff, we take artificial cutoffs at dependency ratios of $0.5,0.75$, and 1 . With the other sample, we take artificial cutoffs at dependency ratios of 2.5, 2.75, and 3. The estimation results, provided in Table B2 in Appendix B, indicate no evidence of a policy effect at the artificial cutoff values that exceeds the statistical expectations. ${ }^{32}$

\subsection{Other Issues on Identification}

Finally, we discuss how our RDD can disentangle the effect of ESSN transfers from the effect of educational programs. Our RDD compares households just above and just below the dependency ratio cutoff by gradually zooming in around the cutoff. However, we have no reason to expect that

\footnotetext{
${ }^{32}$ We have 114 set of estimates, given the 6 different artificial cutoffs and 19 outcomes. Of these, only 9 ( 7.9 percent) yield an effect that is statistically significant at the 10 percent level; 7 yield (6.1 percent) an effect that is statistically significant at the 5-percent level; and none yields an effect that is statistically significant at the 1-percent level.
} 
the effects of other educational programs will be different on either side of the cutoff, because their eligibility conditions do not depend on family composition and dependency ratio. For instance, the transfer amounts in the CCT program vary by gender and age, but children in all refugee households are eligible. The other major educational intervention, PICTES, discussed in Section 2.3, improves schooling infrastructures and provides support for refugee children of all households.

At the same time, the existence of the PICTES program is likely to be crucial for the effectiveness of the ESSN program. While the ESSN program alleviates refugee households' financial constraints that might prevent them from enrolling their children in school, households are more likely to keep their children enrolled in school if their children actually benefit from schooling. In this sense, the PICTES program provides support (in the form of Turkish language education, early childhood education, catch-up or remedial courses, education in Arabic, transport support) that contributes to the development of a schooling infrastructure which serves refugee children. The existence of this schooling infrastructure would allow the ESSN program to potentially push refugee children to school by alleviating their households' financial constraints.

\section{Results}

\subsection{Main Results}

Figure 1 illustrates the relationship between beneficiary status and the dependency ratio. We show the fraction of beneficiaries by dependency ratio without controls in panel (A), and controlling for other eligibility criteria in panel (B). ${ }^{33}$ In each panel, two plots are given: (i) for the full sample, (ii) for the sample with dependency ratios between 0 and 3. In all plots, linear regressions are fit on each side of the cutoff, and the 95-percent confidence intervals are provided. All plots indicate a significant jump at the cutoff value of the dependency ratio. In panel (A2), the percentage of households receiving benefits jumps from just above 40 percent to almost 80 percent.

Figure 2 presents the relationship between our key child labor and school enrollment outcomes and the dependency ratio. The bandwidth for the dependency ratio is restricted to the $[0,3]$ interval

\footnotetext{
${ }^{33}$ Formally, panel (B) uses as a dependent variable the residuals from a regression of beneficiary status on eligibility status based on any one of the other five eligibility criteria.
} 
so that the intervals on each side of the cutoff are equal. The figure shows a marked drop in the number and share of children working and those not enrolled in school. A drop in the same four outcomes is also observed for boys. However, no obvious drop at the cutoff is observed in the number or the share of girls working; this might be due to the much lower incidence of employment among girls. A drop in the number and share of girls not in school, however, is more visible.

Table 2 gives our RDD estimation results for beneficiary status, the number of children working, and the number of children not in school. In panel (A), in addition to the policy dummy and the split linear polynomials on either side of the cutoff, the controls include eligibility status via any one of the other five criteria and dummy variables for different values of the number of children (for different values of the number of boys (girls) when the dependent variable is for boys (girls)). In panel (B), we use the full set of controls, as outlined in the Data Section. In each panel, several bandwidths are used. We use the full data in the first row and gradually narrow the bandwidth, zooming in around the cutoff, while keeping the number of observations and the number of clusters reasonably high. The results are highly similar in both panels, and we discuss the estimates in panel (B) with full controls.

The results show a substantial effect of the dependency ratio rule on the beneficiary status. The beneficiary status jumps by 35-40 percentage points at the cutoff. As suggested by Figure 2, satisfying the dependency-ratio rule reduces both the number of children working and the number of boys working. The smaller negative effect on the number of girls working is statistically significant only when the bandwidth is between 0 and 3 and marginally statistically insignificant with other bandwidths. Quantitatively, when the bandwidth is between 0 and 3, the dependencyratio rule reduces the number of boys working - predicted at the cutoff value when all other variables are set at their mean - from 0.181 to 0.109 (by 66 percent) and the number of girls working from 0.042 to 0.025 (by 69 percent). ${ }^{34}$

Satisfying the dependency-ratio criterion also has a substantial effect on the number of children not in school, which is reduced by about 0.2 . By gender, at a bandwidth between 0 and 3 , the number of boys not in school falls by 0.11 , from 0.364 to 0.254 (a fall of 44 percent) and the number of girls not in school drops by 0.081 , from 0.336 to 0.255 (a fall of 32 percent). In other

\footnotetext{
${ }^{34}$ The predicted values are estimated when the beneficiary status variable is switched on and off at the cutoff. The other control variables are set at their mean values.
} 
words, the effect on boys' school enrollment is somewhat larger. The magnitude of the decline in the number of children working and that in the number of children not in school together suggest that, of the 0.11 reduction in the number of boys not in school, about two-thirds (0.072) at most is attributable to boys who move from employment to school-assuming that boys who leave employment do so for school enrollment. ${ }^{35}$ On the other hand, most of the girls who are driven to school are those who would stay at home otherwise.

Table 3 examines the effect of the dependency-ratio criterion on the shares of children working and the share of children not in school by gender, using the same format as Table 2 . The qualitative findings are the same as those in Table 2, except that the negative effect on the share of girls working turns statistically significant. Table $\mathrm{C} 1$ in Appendix $\mathrm{C}$ shows that our findings are robust when the dependent variables are defined as dummy variables for any child working and for any child not in school, and Figure C1 provides the corresponding RDD graphs.

Table 4 presents the results on the effect of the dependency ratio criterion on the number of children working and the number of children not in school using local polynomial approaches with a uniform kernel. ${ }^{36}$ In panel (A), we use the optimal bandwidth of IK. Here, the optimal bandwidths range from 0.54 to 1.03 , depending on the outcome. Since the narrowest bandwidth we take in the parametric approach is 1.0, these non-parametric bandwidths are, on average, narrower. At the same time, panel (A) also takes alternative bandwidths of $b / 2,3 b / 2$, and $2 b-$ where $b$ stands for the estimated optimal bandwidth. The estimate patterns are highly similar to those with the parametric approach shown in Table 2, except for those with the $b / 2$ bandwidth, which is very narrow. Quantitatively, the coefficient estimates in the first row, i.e. those with the optimal bandwidth, are also similar to those in panel (A) of Table 2 (where baseline covariates are used, as in the local polynomial approach).

In panel (B), we use the CCT optimal bandwidths. Three sets of estimates are provided: (i) conventional RD estimates with a conventional variance estimator, (ii) bias-corrected RD estimates with a conventional variance estimator, (iii) bias-corrected RD estimates with a robust

\footnotetext{
35 The 2018 TDHS indicate that combining school enrollment and child work together is very uncommon among refugees in Turkey.

${ }^{36}$ Table C2 in Appendix C provides the same analysis with a triangular kernel instead. The estimates change little.
} 
variance estimator. ${ }^{37}$ Similar to the parametric approach and the optimal IK bandwidths, the results obtained by using CCT optimal bandwidths indicate a significant effect on all employment and schooling outcomes (except for the number of girls working). The magnitude of the effect on child work is slightly smaller than with the other approaches, but the effect on schooling is equally large. ${ }^{38}$ Table C3 in Appendix C provides the results of local polynomial regressions when the dependent variables are defined as shares, rather than numbers, and shows that the patterns of the estimates are similar to those in Table 3 .

In Table 5, we estimate 2SLS regressions to find the effect of being a beneficiary on children's employment and enrollment outcomes, in terms of both the number and share of children. The qualitative findings match the reduced-form results. Quantitatively, calculated at a bandwidth of dependency ratio ranging from 0 to 3, receiving ESSN transfers reduces the fraction of boys not in school from 28.4 percent to 10.4 percent (by 64 percent) and lowers the fraction of girls not in school from 24.9 percent to 10.3 percent (by 59 percent). It lowers the share of boys working from 17.0 percent to 2.4 percent (by 86 percent) and the share of girls working from 3.3 percent to 0.2 percent (by 95 percent). When we do not differentiate by gender, being a beneficiary reduces the fraction of children working from 14.0 percent to 1.6 percent (by 88 percent) and the fraction of children not in school from 36.2 percent to 13.7 percent (by 62 percent). In sum, the policy has a tremendous role in reducing child labor and a substantial role in increasing school enrollment.

We also conduct 2SLS regressions using a local polynomial approach with IK optimal bandwidths. The results, given in Table C4 in Appendix C, indicate that while the evidence of a negative effect of cash transfers on the share of children working (shown in Table 5) remains, the negative effect on the share of children not in school is marginally statistically insignificant with the optimal bandwidth. With the wider bandwidths ( $3 b / 2$ and $2 b$ ), however, statistical significance emerges for both child labor and schooling variables. Moreover, quantitatively, the 2SLS coefficient

\footnotetext{
${ }^{37}$ Our preferred estimates here are the robust bias-corrected estimator in (iii), as suggested by Cattaneo et al. (2017), although the results are quite similar across the three estimators.

${ }^{38}$ In the CCT approach, we also check the robustness of our results to the use of alternative bandwidth calculations. Particularly, the optimal bandwidths change by the bandwidth type (MSE-optimal or CER-optimal), whether the bandwidth on either side of the cutoff is forced to be common or not, and the degree of local polynomials. The six tables that illustrate these results show that the results are overall robust. (These tables are available on request.)
} 
estimates with the local polynomial approach are about 20 percent larger in absolute value for both child labor and schooling variables than those in Table $5 .{ }^{39}$

\subsection{Channels}

This subsection turns to the potential mechanisms through which the reduction in child labor and the increase in schooling operate. Figure 3 illustrates how income, poverty, housing index and asset holdings change at the cutoff of dependency ratio. Panel (A) shows a significant jump at the cutoff in cases where cash transfers are the main source of income for refugee households. Panel (B) indicates a similar but smaller jump in cases where cash transfers are the secondary or third income source. These results suggest that ESSN transfers significantly increase the household income of beneficiaries. Panels (C) to (F) show the resulting change for certain poverty gap measures at the cutoff. While the 95-percent confidence intervals overlap for the 5.5 USD povertyline measures in panels (C) and (D), the plots in panels (E) and (F) suggest a more visible drop at the cutoff in the measures of extreme poverty. Finally, panels $(\mathrm{G})$ and $(\mathrm{H})$ indicate no notable jumps at the cutoff for the housing index or asset index, respectively.

Table 6 shows the 2SLS estimation results for the effects of being a beneficiary household on income, poverty, housing conditions and assets. First, as can be seen from the table, ESSN cash transfers are the main source of income for half of the beneficiaries and the secondary or tertiary source of income for more than 30 percent of the beneficiaries. However, there is no evidence of an effect of cash transfers on the housing index or asset holdings. Here, the effect magnitudes are also small in terms of percent change (predicted at the cutoff value according to the estimates in Table 6).

In terms of poverty, there is no evidence that being a beneficiary has an effect on the poverty gaps with a 5.5 USD line (note that this is not due to large standard errors). Strong evidence does exist, however, that receiving cash transfers reduces both the extreme poverty gap and the squared extreme poverty gap. Quantitatively, with a bandwidth range of 0 to 3, receiving the cash transfer lowers the extreme poverty gap from 0.046 to 0.013 (by 72 percent) and the extreme squared poverty gap from 0.020 to virtually zero. This suggests that, while transfer levels are high enough

\footnotetext{
${ }^{39}$ The estimates with the b/2 bandwidth — which is very narrow—are quite different, as in the reduced form case. In fact, with this bandwidth, no first stage exists, as can be seen in panel (B) of Table C4.
} 
to reduce extreme poverty, they are not high enough to address poverty as defined by the 5.5 USD PPP threshold. This finding is consistent with the modest amount of transfer received (4 TL per day per capita, for a poverty line equal to $12.2 \mathrm{TL}-5.5$ USD PPP).

Figure 4 displays consumption, coping strategies, and child health before and after the cutoff. Panels (A) to (C) indicate a jump in the cutoff in consumption spending per person, food spending per person, and non-food spending per person. This corroborates the importance of ESSN transfers as a source of income, shown above. Panels (D) and (E) suggest little change around the cutoff for the food consumption score (FCS) and the reduced coping strategy index (rCSI, which indicates behavior related to food consumption), ${ }^{40}$ as the confidence intervals overlap substantially. This is consistent with the relatively high average FCS in our sample. On the other hand, a significant drop at the cutoff in adverse livelihood coping strategies employed is observed in panel (F). ${ }^{41}$ Finally, another mechanism that might explain higher school enrollment for children is an improvement in their health outcomes generated by the cash transfers. However, no notable jump is observed in the variables that measure child health in panels $(\mathrm{G})$ and $(\mathrm{H})$.

Table 7 presents the effect of being a beneficiary household on the same variables (consumption, food security, and coping strategies). The effects on consumption variables (per capita consumption, food and non-food spending) are positive and large-except for those estimated with narrow bandwidths - but they are statistically insignificant. Quantitatively, at a bandwidth range of 0 to 3 , being a beneficiary raises annual consumption from approximatively 4,000 TL to 4,830 TL (by 21 percent); food spending from 2,000 TL to 2,350 TL (by 17 percent); and non-food spending from 2,010 TL to 2,460 TL (by 22 percent). Although these are sizeable effects, the statistical significance is below conventional levels, presumably due to our sample size and our conservative method of estimating standard error by clustering at the dependency ratio. There is no conclusive evidence of an effect on the food consumption score. Although the results with narrow bandwidths indicate improvement, this finding is not robust with other bandwidths. On the other hand, the results show a clear improvement in coping strategies. The reduced coping strategy

\footnotetext{
${ }^{40}$ As described in Section 3.1, these strategies imply a change or a drop in food consumption due to a lack of income.

${ }^{41}$ As presented in Section 3.1, these strategies include selling household goods, borrowing money, reducing essential, non-food expenditure such as education or health, marriage of children under age 16, begging, accepting high risk or illegal, exploitative temporary jobs, and sending an adult member to Syria to seek work.
} 
index falls from 15.9 to 12.2 (by 23 percent), and the livelihood coping strategies index drops from 2.06 to 1.41 (by 32 percent). In sum, we find only suggestive evidence (effects that are economically but not statistically significant) of an increase in consumption and food consumption score and more conclusive evidence of a reduction in the use of harmful coping strategies. Finally, Table 7 presents no evidence of an effect of the cash transfers on children's health.

We examine how the reasons for not sending children to school vary around the dependency-ratio cutoff in Figure 5. Panels (A) and (B) show a drop in responses which indicate that "children need to work" and "children need to stay home and assist family" - suggesting a shift from market and home production to school. While a drop is observed for the incidence of families' not sending a child to school because of schooling costs in panel (C), the confidence intervals overlap —although the upper confidence interval on the right-hand side of the cutoff is still lower than the mean value on the left-hand side. In panel (D), for the incidence of a child not attending school due to health reasons, the confidence intervals overlap substantially.

Table 8 presents strong statistical evidence that cash transfers reduce the incidence of children not enrolled in school for reasons of needing to work or needing to help at home. The negative effect on the incidence of children not enrolled in school because their family cannot afford it is weakly statistically significant for one bandwidth and marginally statistically insignificant for all other bandwidths. On the other hand, lack of enrollment for health reasons has no statistical support. Quantitatively, when a bandwidth range between 0 and 3 is considered, cash transfers reduce the incidence of children not enrolled for reasons of needing to work by 14.4 percentage points, from 19.0 to 4.6 percent (by 76 percent). They also lower the incidence of children not enrolled for reasons of needing to help at home by 5.8 percentage points and virtually eradicate non-enrollment for this reason. At the same time, they reduce non-enrollment due to the monetary costs of schooling by 5.6 percentage points from 7.0 to 1.4 percent (by 80 percent). In sum, these findings imply that ESSN transfers increase the likelihood that children will be sent to school because they address both the opportunity costs and the direct cost of schooling - although the statistical evidence for the former channel is stronger.

\subsection{Heterogeneity}

In this subsection, we examine how the effect of cash transfers varies by children's age and certain household characteristics. First, we examine variation in the effect on children' educational 
outcomes by age group (as explained in Section 3; this information is available only in the CVME4, and information on employment outcomes by age is not available in any survey). Examining the results by age is important because the opportunity cost of schooling in terms of the value of market work and the value of home production changes with age. For instance, this opportunity cost in terms of the value of market work would increase by age, especially among boys.

Panel (A) of Table 9 illustrates the effect of being a beneficiary on the number and share of children not in school for two age groups: 6-11 and 12-17. As can be seen from the table, the effect on the share of children not in school is larger for the older group. When a bandwidth in the range of 0 to 3 is taken, being a beneficiary reduces the fraction of 6- to 11-year-old children not in school by 12.7 percentage points - from 14.8 to 2.0 percent (by 86 percent). It also reduces the fraction of 12- to 17-year-old children not in school by 20.6 percentage points-from 33.8 to 13.2 percent (by 61 percent). The pre-policy level of children not in school is higher for the older age group, as the marginal utility obtained from market work and home production is higher for them. For this reason, cash transfers have a larger impact on their school enrollment.

Panel B shows heterogeneity in the effect of cash transfers by the educational attainment of the household head. A negative effect of cash transfers is observed on the share of children working and the share not in school for household heads with no school degree and for those with primary to high school degrees, but not for those with a university degree. The magnitude of the effect is larger for households whose head has no school degree. Assuming that the education level of the household head is a good proxy for household income, these findings are consistent with the argument that cash transfers improve schooling by covering the direct and opportunity costs of schooling for poor families.

Next, we examine heterogeneity in the impact of the cash transfers by the per-capita consumption level of households (Panel C). The reduction in child labor due to being a beneficiary is much higher among the poorest quintile — most of whom in our sample are under the extreme poverty line. In terms of children's school enrollment, receiving cash transfers has a much stronger effect for the lowest two quintiles. In fact, all refugees in these two quintiles are below the 5.5 USD poverty line. In essence, cash transfers are most effective for the most deprived refugee households. 
Finally, Panel D shows that cash transfers have no effect on families who arrived in Turkey in the preceding 12 months, but they have a statistically significant effect on families who arrived 1 to 3 years or more before the survey was conducted. Recently arrived refugees may have more difficulties settling and navigating the administration, which may explain this lack of impact. It is also important to note that recent arrivals display higher levels of poverty and more often resort to harmful coping mechanisms (Table A3 in Appendix A). Hence, cash transfers might not be able to alleviate their specific financial constraints. The effect of transfers is stronger for Syrians (Panel E), for whom the ESSN program was designed. The incidence of child labor is significantly higher among Syrian refugees than other refugee groups (10.1\% vs $4.3 \%$ among boys and $2.3 \%$ vs. $0.5 \%$ among girls, as presented in Table A3 in Appendix A). School non-enrollment is also slightly higher, which contributes to the higher estimated effects for Syrians. Finally, the effect of cash transfers does not seem to vary by refugee intensity (Panel F), where high refugee intensity areas cover the five NUTS-2 regions with the highest ratio of refugees to natives, based on data from the DGMM on regional distribution of refugees.

\section{Further Robustness Checks}

We have already demonstrated the robustness of our findings in the previous section in a number of ways: (i) robustness to alternative definitions of the dependent variable, (ii) robustness to alternative estimation methods (parametric vs. nonparametric), (iii) robustness to alternative bandwidths, and (iv) robustness to alternative sets of control variables. ${ }^{42}$ In this section, we conduct further robustness checks with a donut-hole RDD estimation, an alternative identification strategy and an alternative dataset.

\subsection{Donut-Hole RDD}

In our checks on assumptions of the RDD method, we have already presented supporting evidence for the absence of manipulation around the cutoff. Here, we conduct a donut-hole RDD analysis where we exclude the points immediately surrounding the cutoff. First, we drop the point right at the cutoff, where dependency ratio takes the value of 1.5. Table D1 in Appendix D presents the

\footnotetext{
${ }^{42}$ As a further robustness check, we add a control variable for the receipt of any assistance other than the ESSN. In fact, $16 \%$ of the respondent households (17\% of the beneficiaries) state that they received assistance from sources other than the ESSN in the last 30 days. The results remain unchanged.
} 
results on the shares of children working and of children not in school with this exclusion. We then extend the width of the donut-hole to a range of 1.25 to 1.75; Table D2 shows the results. An examination of both tables shows that the results are overall quite robust. However, the estimates become more fragile (especially with the wider donut hole) as we gradually narrow the bandwidth (which is to be expected with a wide donut hole with a narrow bandwidth around it).

\subsection{Propensity Score Matching}

As a robustness check, we use propensity score matching (PSM) as an alternative identification strategy to estimate the impacts of the program and complement our main analysis (Caliendo and Kopeinig, 2008; Rosenbaum and Rubin, 1983). Here, we summarize our findings using PSM. Additional discussions and robustness checks are provided in Appendix E.

We match beneficiary households to non-beneficiary applicants based on observable characteristics that are unlikely to be affected by the program (Figure E1 in Appendix E). The matching is efficient at reducing the difference in observed characteristics of the treatment and control groups. However, the common support between these two groups remains limited (Figure E2 in Appendix E), which is not surprising given the selection criteria used by the ESSN program. Other unobservable differences between the two groups may also affect the estimation. For these reasons, PSM is used as a robustness check rather than as our main identification strategy.

In Table F1, we show the impacts of ESSN transfers on the number of children working or not going to school, decomposed by gender, using PSM. Table E2 presents similar results for the share of children working or not going to school. These results are qualitatively similar to the results of our main analysis, where we used RDD. Using PSM, we find a reduction in the number of children working by 0.12 , and a decrease in the number of children not going to school by 0.24 . Compared to average values among non-beneficiary applicants, these figures correspond to a decrease of $69 \%$ in children working and 53\% in children not going to school. Similar results and magnitudes are obtained for the share of children working and not going to school. Overall, the PSM estimation confirms the robustness of our main results.

\subsection{Analysis with the PDM Data}

As a final robustness check, we estimate the results using our main RDD estimation strategy with a different dataset. For this analysis, we use the PAB/PDM (Pre-Assistance Baseline and Post- 
Distribution Monitoring) surveys conducted by the WFP with support from TRC and the World Bank (WFP, 2019c). The PAB/PDM surveys have the advantage of a panel structure, but compared to the CVME surveys, they provide considerably less information on our key outcomes of interest, education and child labor, among other important limitations. ${ }^{43}$ We therefore use this dataset only to conduct robustness checks. We analyze the fourth wave of the PDM survey (PDM4, conducted between April and August 2018), which corresponds to the end period of the CVME3 survey used for our main analysis. The PDM4 dataset provides information for 6,184 households with beneficiary status and allows us to construct the dependency ratio to apply our main RDD identification strategy. We show in Appendix F the effect of the dependency ratio and the effect of being beneficiary (2SLS) on four available variables: i) putting children to work in the previous 30 days because of food insecurity, ii) removing children from in the previous 30 days because of food insecurity, iii) having at least one child not in school, and iv) the number of children not in school.

Table F1 in Appendix F shows the effect of the dependency-ratio rule using the RDD estimation applied in the PDM4 dataset. We find that the ESSN program is efficient in decreasing the use of child labor, as households above the 1.5 dependency-ratio cutoff are about 5.5 percentage point less likely to use this harmful coping strategy in case of loss of income (bandwidth between 0 and 3). The impact on "removing children from school" as a coping strategy is not significant for most bandwidths, which is most likely due to the timing of the survey (conducted during the summer months when schools are not in session). The transfers also have a large impact at the cutoff on the likelihood of having at least one child not in school and on the number of children not in school, which drops by 8 percentage points and 0.15 , respectively. Using 2SLS to measure the effect of being a beneficiary of the ESSN program (given in Table F2 of Appendix F), we find a 19 percentage point drop in the use of child labor as a coping strategy, a 31 percentage point decrease in the likelihood of having at least one child not in school, and a 0.6 drop in the average number

\footnotetext{
${ }^{43} \mathrm{PAB} / \mathrm{PDM}$ surveys do not include information on child labor, except as a coping strategy for households who put children to work in the last 30 days as a response to a shock. The surveys do not include information on children at school disaggregated by gender either. In addition, the PDM survey is conducted over the phone, which generates additional limitations and results in a high attrition rate which differs across beneficiaries and non-beneficiaries (WFP, 2019c; Ozler et al., 2020). Finally, the survey does not ask directly about the number of children not at school, which leads to measurement errors when generating this variable based on the number of children at school and the total number of children (e.g. a negative number of children not at school, which we treat as zero).
} 
of children not in school. These results are overall consistent with our main findings based on the CVME datasets.

\section{Conclusion}

In this study, we investigate how cash transfers affect refugee household decisions to send children to work and to school, drawing on survey data from the world's largest cash transfer program for refugees, the ESSN program in Turkey. Using a regression discontinuity design, we show that the ESSN program has a substantial effect both on child labor and school enrollment. The program reduces the fraction of children working from 14.0 to 1.6 percent (by 88 percent) and the fraction of children aged 6-17 not in school from 36.2 to 13.7 percent (by 62 percent). Our findings also indicate a larger impact of cash transfers on schooling for older children than younger childrenwhich is consistent with the higher opportunity cost of schooling for older children. In addition, we find that the effects on child labor and schooling are larger among lower-income households, implying that the children who benefit most from the ESSN program are those in poorer families.

We uncover several mechanisms at play in the improvement of children's schooling and work outcomes. First, ESSN cash transfers are an important source of income for about 80 percent of the beneficiary households, substantially lowering extreme poverty among refugees. Second, we find suggestive evidence of an increase in consumption and food consumption score and we find conclusive evidence of an improvement in coping strategies related to consumption and in other livelihood coping strategies. Our findings also show that ESSN transfers increase the likelihood of parents' sending children to school because the transfers address the opportunity costs of schooling, in that they lower the marginal utility of income obtained from children's market work and home production. We also find suggestive evidence that cash transfers allow households to address the direct cost of schooling.

In essence, this study shows that a multi-year program that provides modest, regular cash transfers produces a tremendous increase in the schooling enrollment of refugee children and a decline in their employment, made possible because households have overcome their financial constraints. The program helps children in the poorest families the most - a finding that is consistent with the "luxury axiom" of Basu and Van (1998), which states that families who reach a certain level of income will choose not to put their children to work. Our findings hold true in the context of the 
country that hosts the largest refugee group, most of whom do not live in camps. In addition, the amount of the cash transfers that achieve such success is modest in absolute value; it is equal to $30 \%$ of the average monthly consumption value of the refugee households in our sample.

This study also contributes to discussions in the literature about whether or not cash transfers that aim to improve children's schooling outcomes need to be conditional on school attendance. Despite additional, non-financial constraints that carry particular importance for refugee children, we show that in this particular setting, providing cash alone, without conditions, generates large, positive impacts on child labor and schooling outcomes. At this point, it is important to highlight the existence of other schooling programs targeting refugees in Turkey that improved the schooling infrastructure for refugees, thus creating conditions that allowed ESSN cash transfers to work better.

The socioeconomic conditions of Syrian refugees in Turkey - characterized by poverty, a high incidence of child labor, and low levels of schooling compared to the local population - are similar to those of other refugee populations in low- and middle-income host countries around the world (including Syrian refugees in other neighboring countries). In the scope of the program that we studied in the Turkish setting, two distinct features have been critical: (1) the existing schooling infrastructure's ability to absorb refugee children and its openness to refugees and (2) the existence of complementary policies that supported the integration of Syrian refugees in the schooling system. Our findings can therefore be generalized to contexts where school and administrative capacities are high enough to absorb and educate refugee children living outside camps.

The integration of refugee households into host communities is an important policy issue for Syrian refugees, who constitute the world's largest refugee population and who are generally unlikely to return to their country of origin. ${ }^{44}$ This issue is also of global significance at a time when $1 \%$ of the world's population live in forced displacement- among which $40 \%$ are childrenspread across all continents. Failing to integrate refugees poses important threats to the social fabric in the short term (an issue well documented in the media), generates inequalities in education and future incomes, fuels resentment, and can lead to long-lasting social conflicts between host populations and refugees. Conversely, refugee children who stay in school and out of work benefit

\footnotetext{
${ }^{44}$ The ratio of refugees who state they would not return to Syria even if the war ends has been increasing as the conflict continues (Erdogan, 2018).
} 
from a wide range of human, social and (future) financial advantages that alleviate major disruptions caused by forced displacement. In this context, our results have important implications for the design of policies for supporting refugees and fostering their integration into their new society. By focusing on the financial constraints faced by refugees, they provide evidence that cash-based humanitarian assistance can potentially to generate lasting effects for refugee children in environments that are challenging yet supportive. 


\section{References}

Aker, J. C. (2017). Comparing cash and voucher transfers in a humanitarian context: Evidence from the Democratic Republic of Congo. The World Bank Economic Review, 31(1), 44-70.

Akresh, R., De Walque, D., and Kazianga, H. (2013). Cash transfers and child schooling: evidence from a randomized evaluation of the role of conditionality. The World Bank.

Aksu, E., Kirdar, M.G., and R. Erzan (2018) "The Impact of Mass Migration of Syrians on the Turkish Labor Market,” IZA Discussion Papers 12050.

Altindag, O., and O'Connell, S. D. (2020). Unconditional Cash-Based Assistance to the Poor: What Do At-Scale Programs Achieve?. Available at SSRN 3719946.

Arık Akyuz, B.M., Aksoy, D., Madra, A. and Polat, E. (2018). Evolution of National Policy in Turkey on Integration of Syrian Children into the National Education System. Background paper prepared for the UNESCO 2019 Global Education Monitoring Report. Retrieved from http://unesdoc.unesco.org/images/0026/002660/266069e.pdf (Access date: 10/02/2021)

Attanasio, O., Fitzsimons, E., Gomez, A., Gutierrez, M. I., Meghir, C., and Mesnard, A. (2010). Children's schooling and work in the presence of a conditional cash transfer program in rural Colombia. Economic Development and Cultural Change, 58(2), 181-210.

Baird, S., McIntosh, C., and Özler, B. (2011). Cash or condition? Evidence from a cash transfer experiment. The Quarterly Journal of Economics, 126(4), 1709-1753.

Baird, S., Ferreira, F. H., Özler, B., and Woolcock, M. (2014). Conditional, unconditional and everything in between: a systematic review of the effects of cash transfer programmes on schooling outcomes. Journal of Development Effectiveness, 6(1), 1-43.

Basu, K. (1999). Child labor: cause, consequence, and cure, with remarks on international labor standards. Journal of Economic Literature, 37(3), 1083-1119.

Basu, K., and Van, P. H. (1998). The economics of child labor. American Economic Review, 412427.

Battistin, F. (2016). Impact evaluation of the multipurpose cash assistance programme. Beirut: Lebanon Cash Consortium. Available at: https://reliefweb.int/sites/reliefweb.int/files/resources/LCCImpactEvaluationforMCAFebruar y2016FINAL.PDF(Access date: 13/03/2021).

Beegle K., Dehejia, R. and Gatti, R. 2009. "Why Should We Care about Child Labor? The Education, Labor Market, and Health Consequences of Child Labor", Journal of Human Resources, 44(4): 871-889.

Brück, T., Cuesta, J., De Hoop, J., Gentilini, U., and Peterman, A. (2019). Social Protection in Contexts of Fragility and Forced Displacement: Introduction to a Special Issue. The Journal of Development Studies 55 (sup1): 1-6

Calonico, S., Cattaneo, M. D., and Titiunik, R. (2014). Robust Nonparametric Confidence Intervals for Regression-Discontinuity Designs. Econometrica, 82(6), 2295-2326. 
Caliendo, M., and Kopeinig, S. (2008). Some practical guidance for the implementation of propensity score matching. Journal of Economic Surveys, 22(1), 31-72.

Cattaneo, M., Jansson, M., and Ma, X. (2018). Manipulation testing based on density discontinuity. Stata Journal 18(1), 234-261.

Cuevas, P. Facundo, O. Kaan, Inan, Aysha Twose, and Çiğdem Çelik (2019). Vulnerability and Protection of Refugees in Turkey: Findings from the Rollout of the Largest Humanitarian Cash Assistance Program in the World. World Bank and World Food Programme.

Dammert, A. C. (2009). Heterogeneous impacts of conditional cash transfers: Evidence from Nicaragua. Economic Development and Cultural Change, 58(1), 53-83.

Dayioglu, M., and Kirdar, M. G. (2020). Keeping Kids in School and Out of Work: Compulsory Schooling and Child Labor in Turkey. IZA Discussion Paper No: 13276.

Dayioglu, M., Kirdar, M. G., and Koc, I. (2021). The making of a lost generation: Syrian child laborers in Turkey. Mimeo.

De Coninck, D., Ogan, C., and d'Haenens, L. (2020). Can 'the Other'ever become 'One of Us'? Comparing Turkish and European attitudes toward refugees: A five-country study. International Communication Gazette, 1748048519895376.

De Janvry, A., Finan, F., Sadoulet, E., and Vakis, R. (2006). Can conditional cash transfer programs serve as safety nets in keeping children at school and from working when exposed to shocks?. Journal of Development Economics, 79(2), 349-373.

Del Carpio, X. V., Loayza, N. V., and Wada, T. (2016). The impact of conditional cash transfers on the amount and type of child labor. World Development, 80, 33-47.

Dumas, C. (2012). Does work impede child learning? The case of Senegal. Economic Development and Cultural Change, 60(4), 773-793.

DGMM (Directorate General for Migration Management) (2020) Statistics - Temporary Protection. Access date: 24/9/2020. https://en.goc.gov.tr/temporary-protection27

Edmonds, E. V. (2006). Child labor and schooling responses to anticipated income in South Africa. Journal of Development Economics, 81(2), 386-414.

Edmonds, E. V., and Schady, N. (2012). Poverty alleviation and child labor. American Economic Journal: Economic Policy, 4(4), 100-124.

Erdogan, M. M. (2018). Suriyeliler Barometresi: Suriyelilerle Uyum İçinde Yaşamın Çerçevesi [Syrian Barometer: The Framework of Social Coherence with Syrians]. İstanbul Bilgi Üniversitesi Yayınları, İstanbul.

Erol, E., A. E. Akyol, C. Salman, E. Pınar, İ. Gümüşcan, K. Y. Mısırlı, M. Kahveci, P. Mutlu (2017). Suriyeli Sığınmacıların Türkiye'de Emek Piyasasına Dahil Olma Süreçleri ve Etkileri: İstanbul Tekstil Sektörü Örneği, [Integration Processes of the Syrian Refugees to the Turkish Labor Markets and its Effects: Case of the Textile Sector in Istanbul] Istanbul: Birlesik Metal Is. Retrieved from: www.birlesikmetal.org/kitap/gocmen2017.pdf (Access date: 10/02/2021) 
ERG (Education Reform Initiative) (2018). Community Building through Inclusive Education. ERG, Istanbul.

Ferris, E. and K. Kirişci (2016) The Consequences of Chaos: Syria's Humanitarian Crisis and the Failure to Protect, Brookings Institution Press, Washington, D.C.

Fiala, N. (2015). Economic consequences of forced displacement. The Journal of Development Studies, 51(10), 1275-1293.

Foster, J., Greer, J., and Thorbecke, E. (1984). A class of decomposable poverty measures. Econometrica 52(3), 761-766.

Foster, J. (2015). Impact of Multipurpose Cash Assistance on Outcomes for Children in Lebanon. Improving Cash Based Interventions Multipurpose Cash Grants and Protection, European Commission Humanitarian Aid and Civil Protection Department, Brussels.

Galiani, S., and McEwan, P. J. (2013). The heterogeneous impact of conditional cash transfers. Journal of Public Economics, 103, 85-96.

Gaunt, A. (2016). UNHCR Cash Assistance: Improving refugee lives and supporting local economies, UNHCR, Geneva.

Giordano, N., Dunlop, K., Gabay T., and Sardiwal D. (2017). Evaluation Synthesis of UNHCR's Cash Based Interventions in Jordan, Action Against Hunger, London.

Grasset, J. (2019). Multi-Purpose Cash Transfer 'Plus': Maximizing impact on children through integrated cash-based programming. Case study from Colombia, United States Agency for International Development and Save the Children, Washington, D.C.

Grootaert, C., and Kanbur, R. (1995). Child labour: An economic perspective. Int'l Lab. Rev., 134, 187.

Habib, R. R., Ziadee, M., Abi Younes, E., Harastani, H., Hamdar, L., Jawad, M., and El Asmar, K. (2019). Displacement, deprivation and hard work among Syrian refugee children in Lebanon. BMJ global health, 4(1).

Hacettepe Üniversitesi Nüfus Etütleri Enstitüsü. (2019a). 2018 Türkiye Nüfus ve Sağlı Araştırması Suriyeli Göçmen Örneklemi, Temel Bulgular. Hacettepe Üniversitesi Nüfus Etütleri Enstitüsü, T.C. Cumhurbaşkanlığı Strateji ve Bütçe Başkanlığı ve TÜBİTAK, Ankara, Türkiye.

Hacettepe Üniversitesi Nüfus Etütleri Enstitüsü. (2019b). 2018 Türkiye Nüfus ve Sağllk Araştırması. Hacettepe Üniversitesi Nüfus Etütleri Enstitüsü, T.C. Cumhurbaşkanlığı Strateji ve Bütçe Başkanlığı ve TÜBİTAK, Ankara, Türkiye.

Hahn J., Todd P.E., van der Klauuw V. (2001). Identification and Estimation of Treatment Effects with a Regression-Discontinuity Design. Econometrica, 69, 201-9. 
Hangartner, D., Dinas, E., Marbach, M., Matakos, K., and Xefteris, D. (2019). Does exposure to the refugee crisis make natives more hostile? American Political Science Review, 113(2), 442455.

Hidrobo, M., Hoddinott, J., Peterman, A., Margolies, A., and Moreira, V. (2014). Cash, food, or vouchers? Evidence from a randomized experiment in northern Ecuador. Journal of Development Economics, 107, 144-156.

de Hoop, J., Friedman, J., Kandpal, E., and Rosati, F. C. (2019). Child Schooling and Child Work in the Presence of a Partial Education Subsidy. Journal of Human Resources, 54(2), 503-531.

de Hoop, J., Groppo, V., and Handa, S. (2019). Cash Transfers, Microentrepreneurial Activity, and Child Work: Evidence from Malawi and Zambia. The World Bank Economic Review.

de Hoop, J., Morey, M., and Seidenfeld, D. (2019). No lost generation: Supporting the school participation of displaced Syrian children in Lebanon. The Journal of Development Studies, 55(sup1), 107-127.

İçduygu Ahmet and Doğuş Şimşek (2016) Syrian Refugees in Turkey: Towards Integration Policies. Turkish Policy Quarterly, 15 (3), 59-69.

Ibáñez, A. M., and Vélez, C. E. (2008). Civil conflict and forced migration: The micro determinants and welfare losses of displacement in Colombia. World Development, 36(4), 659676.

IFRC (2021). Emergency Social Safety Net (ESSN) Monthly Report: February 2021. https://media.ifrc.org/ifrc/wpcontent/uploads/sites/5/2021/03/202102_ESSNMonthlyReport.pdf. Access date: 02/04/2021

ILO (2017). Global Estimates of Child Labour: Results and Trends, 2012-2016, Geneva.

Imbens, G.W., and Angrist, J. (1994) Identification and Estimation of Local Average Treatment Effects. Econometrica 62(2), 467-75.

Imbens, G. W., and Kalyanaraman, K. (2012). Optimal Bandwidth Choice for the Regression Discontinuity Estimator. The Review of Economic Studies, 79(3), 933-959.

IOM (2018). Multi-Sector Needs Assessment of Syrians in Turkey's South-Eastern Provinces. IOM Mission to Turkey: Ankara.

Kirdar, M. G., Dayioglu, M., and Koc, I. (2021). Integration of refugee children into the educational system of host country: Evidence from the biggest refugee group in a single country. Mimeo.

Küppers, B., and Ruhmann, A. (2016). Because we struggle to survive: child labor among refugees of the Syrian conflict. Lausanne: Terre Des Hommes.

Lee D.S., Lemieux T. Regression Discontinuity Designs in Economics. Journal of Economic Literature 2010, 48(2); 281-355. 
Lehmann, C. and Masterson D. (2014). Impact evaluation of a cash-transfer programme for Syrian refugees in Lebanon. https://www.ennonline.net/fex/48/impactevaluation\#. Access date: 02/04/2021.

Lehmann, M. C., and Masterson, D. T. (2020). Does Aid Reduce Anti-refugee Violence? Evidence from Syrian Refugees in Lebanon. American Political Science Review, 114(4), 1335-1342.

LoPalo, M. (2019). The effects of cash assistance on refugee outcomes. Journal of Public Economics, 170, 27-52.

Maadad, N., and Matthews, J. (2020). Schooling Syrian refugees in Lebanon: building hopeful futures. Educational Review, 72(4), 459-474.

Memişoğlu, F. (2018). The Syrian Community in Turkey: Perspectives, Prospects, and Policies. Public Policy and Democracy Studies (PODEM) Report. Retrieved from: http://podem.org.tr/en/publications/the-syrian-community-in-turkeyperspectives-prospectsand-policies (Access date: 10/02/2021).

Ministry of Family, Labor and Social Services (MoFLSS) (2019). Labor Statistics, Vols. 20112019. Retrieved from: https://www.csgb.gov.tr/istatistikler/calisma-hayati-istatistikleri/resmiistatistik-programi/calisma-hayati-istatistikleri-kitabi/ (Access date: 26/05/2021)

Ministry of National Education (MoNE) Directorate General for Lifelong Learning (2017) 2016 Yılı İzleme Değerlendirme Raporu [Monitoring and Evaluation Report for Year 2016]. Retrieved from:

http://hbogm.meb.gov.tr/dosyalar/izlemedegerlendirmerapor/2016/mobile/index.html (Access date: 10/02/2021).

MoNE Directorate General for Lifelong Learning (2018). 2017 Y1l İzleme Değerlendirme Raporu [Monitoring and Evaluation Report for Year 2017]. Retrieved from http://hbogm.meb.gov.tr/dosyalar/izlemedegerlendirmerapor/2017/mobile/index.html (Access date: 10/02/2021).

MoNE Directorate General for Lifelong Learning (2019) 2018 Y1l İzleme Değerlendirme Raporu [Monitoring and Evaluation Report for Year 2018]. Retrieved from: http://hbogm.meb.gov.tr/dosyalar/izlemedegerlendirmerapor/2018/mobile/index.html

(Access date: 10/02/2021).

MoNE Directorate General for Lifelong Learning (2020a) 2019 Y1lı İzleme Değerlendirme Raporu [Monitoring and Evaluation Report for Year 2019]. Retrieved from: http://hbogm.meb.gov.tr/dosyalar/izlemedegerlendirmerapor/2019/mobile/index.html

(Access date: 10/02/2021).

MoNE Directorate General for Lifelong Learning (2020b) 2019 Y1lı Brim Faaliyet Raporu [Annual Activity Report for Year 2019]. Retrieved from: https://hbogm.meb.gov.tr/meb_iys_dosyalar/2020_03/13111043_2019_Mali_Birim_Faaliyet Raporu.pdf (Access date: 10/02/2021). 
Moussa, W., Irani, A., Salti, N., Al Mokdad, R., Jamaluddine, Z., Chaaban, J., and Ghattas, H. (2021). The Impact of Cash Transfers on Syrian Refugee Children in Lebanon. ERF Working Paper Series; $\quad$ Working $\quad$ Paper $\quad$ No. 1457. https://erf.org.eg/app/uploads/2021/02/1614178280_293_580738_1457.pdf

Ombudsman Institution of the Republic of Turkey (2018). Syrians in Turkey - Special Report. The Ombudsman Institution: Ankara.

Ozler, B., Celik, C., Cunningham, S., Cuevas, P. F., and Parisotto, L. (2020). Children on the Move: Progressive Redistribution of Humanitarian Cash Transfers among Refugees. Policy Research Working Paper; No. 9471. World Bank, Washington, DC https://openknowledge.worldbank.org/handle/10986/34772

Pinedo-Caro, L. (2020). Syrian Refugees in the Turkish Labour Market: A Socio-Economic Analysis. Sosyoekonomi, 28 (46), 51-74.

Ravallion, M., and Wodon, Q. (2000). Does child labour displace schooling? Evidence on behavioural responses to an enrollment subsidy. The Economic Journal, 110(462), 158-175.

Rosenbaum, P. R., and Rubin, D. B. (1983). The central role of the propensity score in observational studies for causal effects. Biometrika, 70(1), 41-55.

Taylor, J. E., Filipski, M. J., Alloush, M., Gupta, A., Valdes, R. I. R., and Gonzalez-Estrada, E. (2016). Economic impact of refugees. Proceedings of the National Academy of Sciences, 113(27), 7449-7453.

Turkish Red Crescent (TRC) (2018). Factsheet 5: Breakdown of Grades and ALP - Conditional Cash Transfer for Education (CCTE) Programme. Retrieved from: https://reliefweb.int/report/turkey/kizilaykart-conditional-cash-transfer-education-ccteprogramme-factsheet-5-breakdown (Access date: 10/02/2021)

TRC (2020) Infographic on Conditional Cash Transfer for Education (CCTE) Programme September 2020. Retrieved from: https://reliefweb.int/report/turkey/turkish-red-crescentconditional-cash-transfer-education-ccte-programme-november-2020 (Access date: 10/02/2021).

UNHCR (2016). Vulnerability assessment of Syrian refugees in Lebanon 2016. Retrieved from: https://reliefweb.int/sites/reliefweb.int/files/resources/VASyR2016.pdf (Access date: 02/04/2021).

UNHCR (2017) Turkey: Education Update - February 2017. Retrieved from: https://data2.unhcr.org/en/documents/details/53953. Access date: 10/02/2021.

UNHCR (2020a). Figures at a Glance. Available at https://www.unher.org/figures-at-aglance.html. Access date: 02/04/2021.

UNHCR (2020b) Syria Regional Refugee Response Operational Data Portal. UNHCR. Available at: https://data2.unhcr.org/en/situations/syria Access date: 24/9/2020. 
UNICEF (2014). No lost generation, protecting the futures of children affected by the crisis in Syria. UNICEF Report. Aivailable at https://reliefweb.int/sites/reliefweb.int/files/resources/No-Lost-Generation-StrategicOverview-January-2014-RV.pdf . Access date: 02/04/2021.

UNICEF (2015). Small Hands Heavy Burden How the Syria Conflict is Driving More Children into the Workforce. Available at https://www.unicef.es/sites/unicef.es/files/child-labourfinal.pdf. Access date: 02/04/2021.

UNICEF (2016) Türkiye'de 'Kayıp bir Kuşak' oluşmasını önlemek. Available at: https://www.unicef.org/turkey/raporlar/t\% $\%$ 3\%BCrkiyedeki-suriyeli-\% $\%$ C3\%A7ocuklar-bilginotu-ekim-2016. Access date: 24/9/2020.

UN Women (2018). Needs Assessment of Syrian Women and Girls under Temporary Protection Status in Turkey. UN Women: Istanbul.

Vaitla, B., Coates, J., and Maxwell, D. (2015). Comparing household food consumption indicators to inform acute food insecurity phase classification. Washington, DC: FHI, 360.

Valli, E., Peterman, A., and Hidrobo, M. (2019). Economic transfers and social cohesion in a refugee-hosting setting. The Journal of Development Studies, 55(sup1), 128-146.

Wiesmann, D.; Bassett, L.; Benson, T.; and Hoddinott, J. (2009). Validating the World Food Programme's Food Consumption Score and Alternative Indicators of Household Food Security. IFPRI Discussion Paper 00870. Washington, DC.

WFP (2016) Syria Crisis Response Highlights Turkey August 2016. Available at: http://documents.wfp.org/stellent/groups/public/documents/op reports/wfp263820.pdf. Access date: 24/9/2020.

WFP (2018) Evaluation of the DG ECHO funded Emergency Social Safety Net (ESSN) in Turkey available at: https://www.wfp.org/publications/turkey-echo-funded-emergency-social-safetynet-evaluation. Access date: 02/04/2021.

WFP (2019a) The Emergency Social Safety Net (ESSN) - Helping Refugees in Turkey https://docs.wfp.org/api/documents/WFP-0000104792/download/ Access date: 24/9/2020

WFP (2019b) Reaching Hidden Populations with an Innovative Two-Stage Sampling Method - A case study from the refugee population in Turkey https://docs.wfp.org/api/documents/WFP0000104292/download/?iframe . Access date: 07/03/2021.

WFP (2019c), ESSN Post-Distribution Monitoring Report - Cross-Section Round 2 (PDM 5). https://reliefweb.int/report/turkey/essn-post-distribution-monitoring-report-cross-sectionround-2-pdm-5 . Access date: 07/03/2021.

Zabaleta, M. B. (2011). The impact of child labor on schooling outcomes in Nicaragua. Economics of Education Review, 30(6), 1527-1539. 


\section{Tables and Figures}

Figure 1: The Effect of Dependency-Ratio Criterion on Beneficiary Status

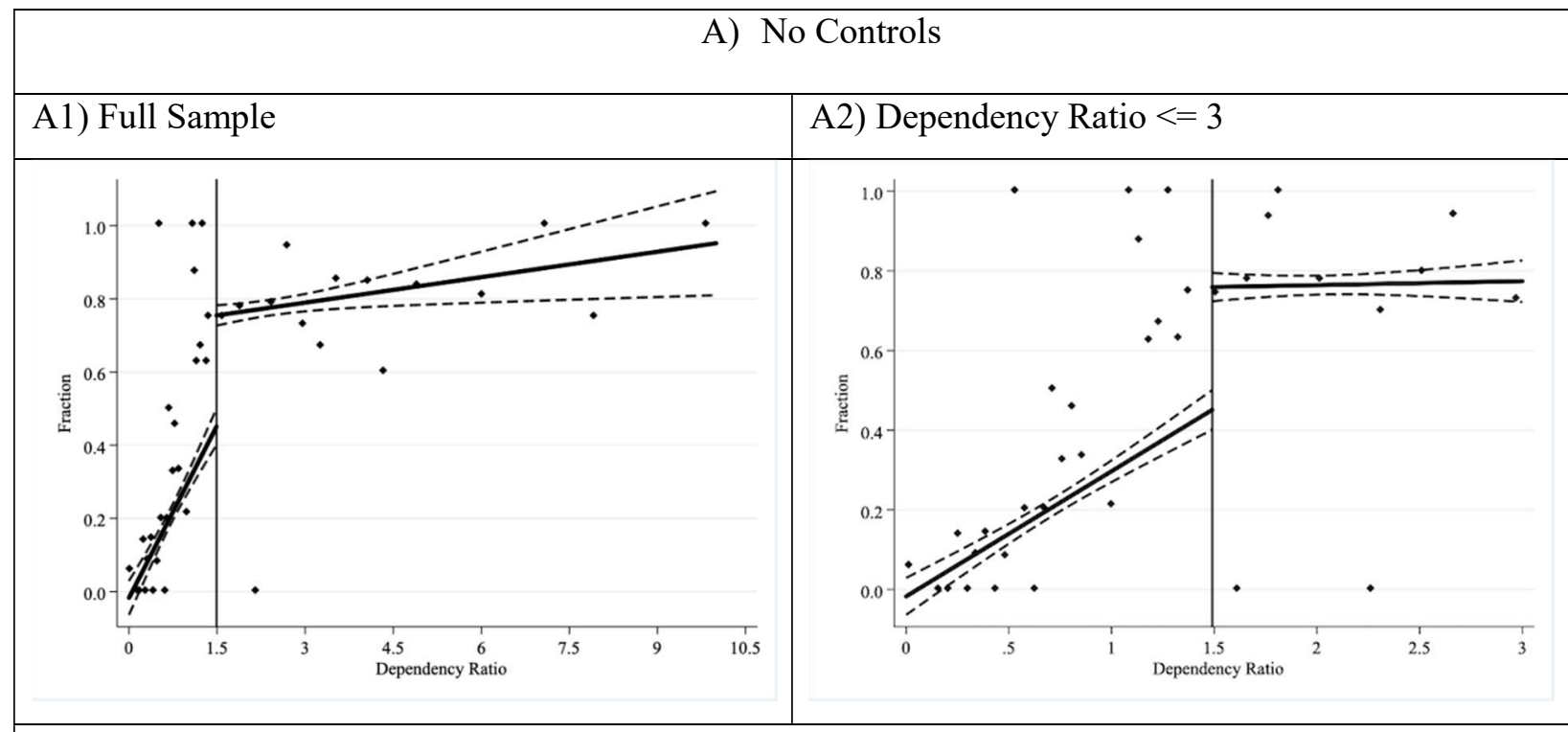

B) Controlling for Eligibility Status based on the Five Criteria other than Dependency Ratio

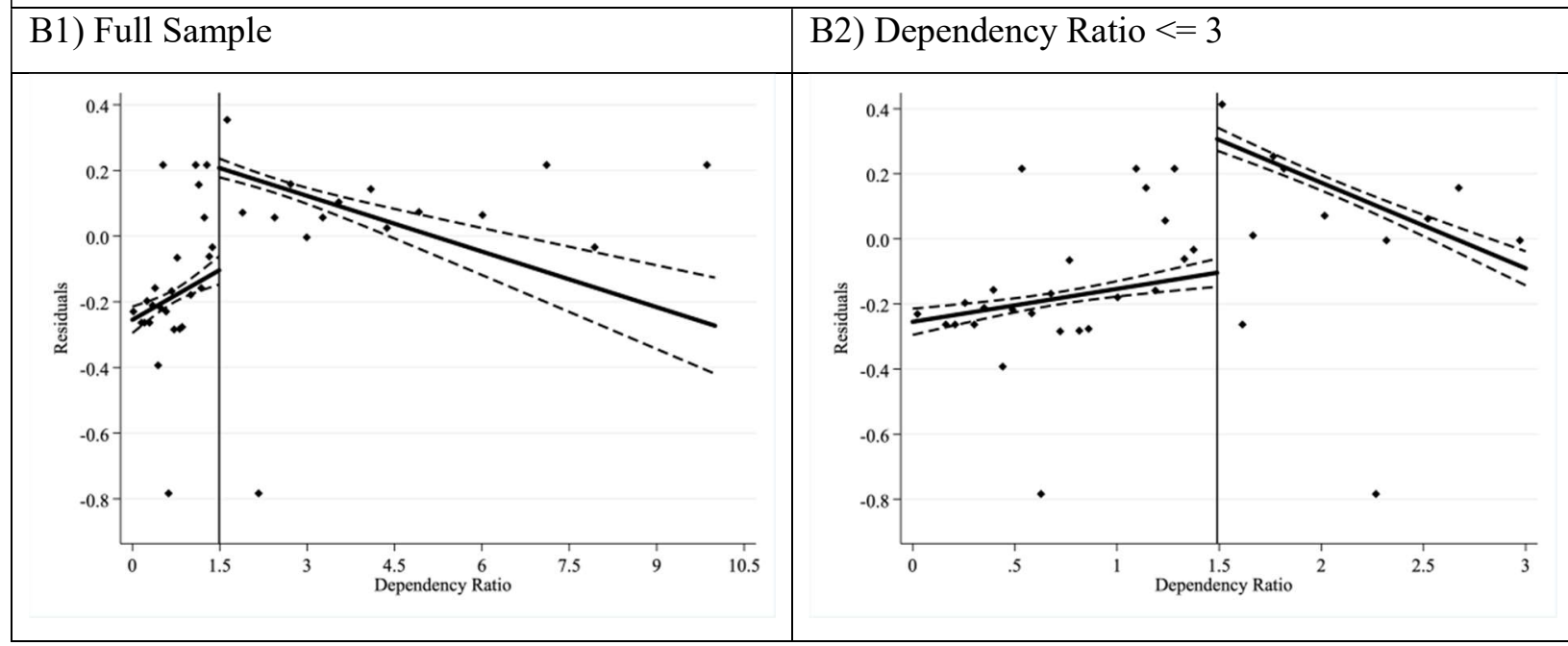

Notes: The dependent variable is beneficiary status in Panel A, and the residuals from a regression of beneficiary status on the five other eligibility criteria in Panel B. Panels A1 and B1 use the full sample, while Panels A2 and B2 use the sample of households with beneficiary ratios between 0 and 3. Linear fits on each side of the 1.5 dependencyratio cutoff and confidence intervals at the $95 \%$ level are provided. 
Figure 2: The Effect of Dependency-Ratio Criterion on Child Labor and Schooling Outcomes

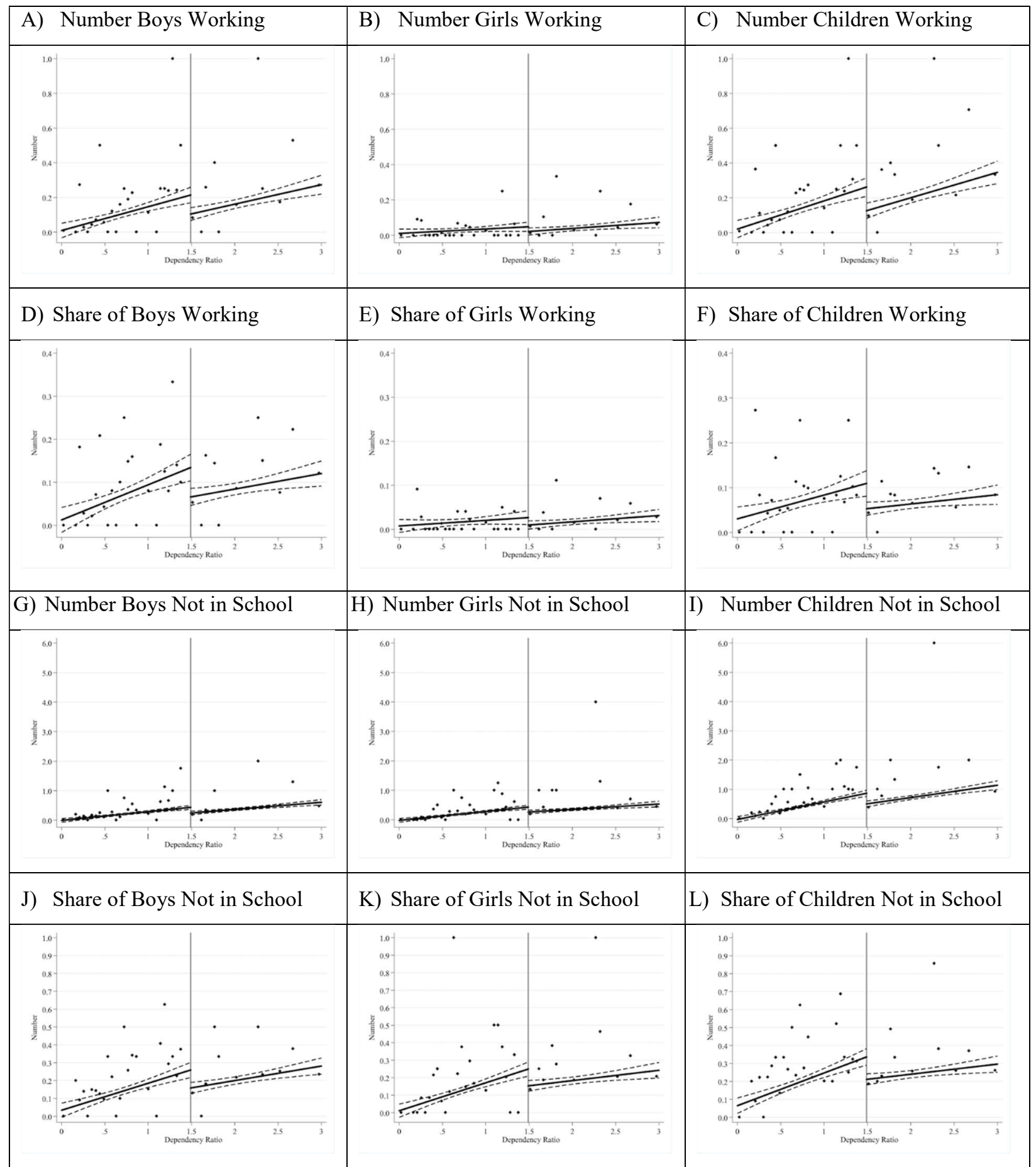

Notes: Figures show the number and share of children (below 18) who worked in the previous 30 days, and the number and share of children (6-17) who did not enroll in school during the previous semester and do not plan to return. The shares are set to zero when no child exists in the household. 
Figure 3: The Effect of Dependency-Ratio Criterion on Income, Poverty, Housing and Assets

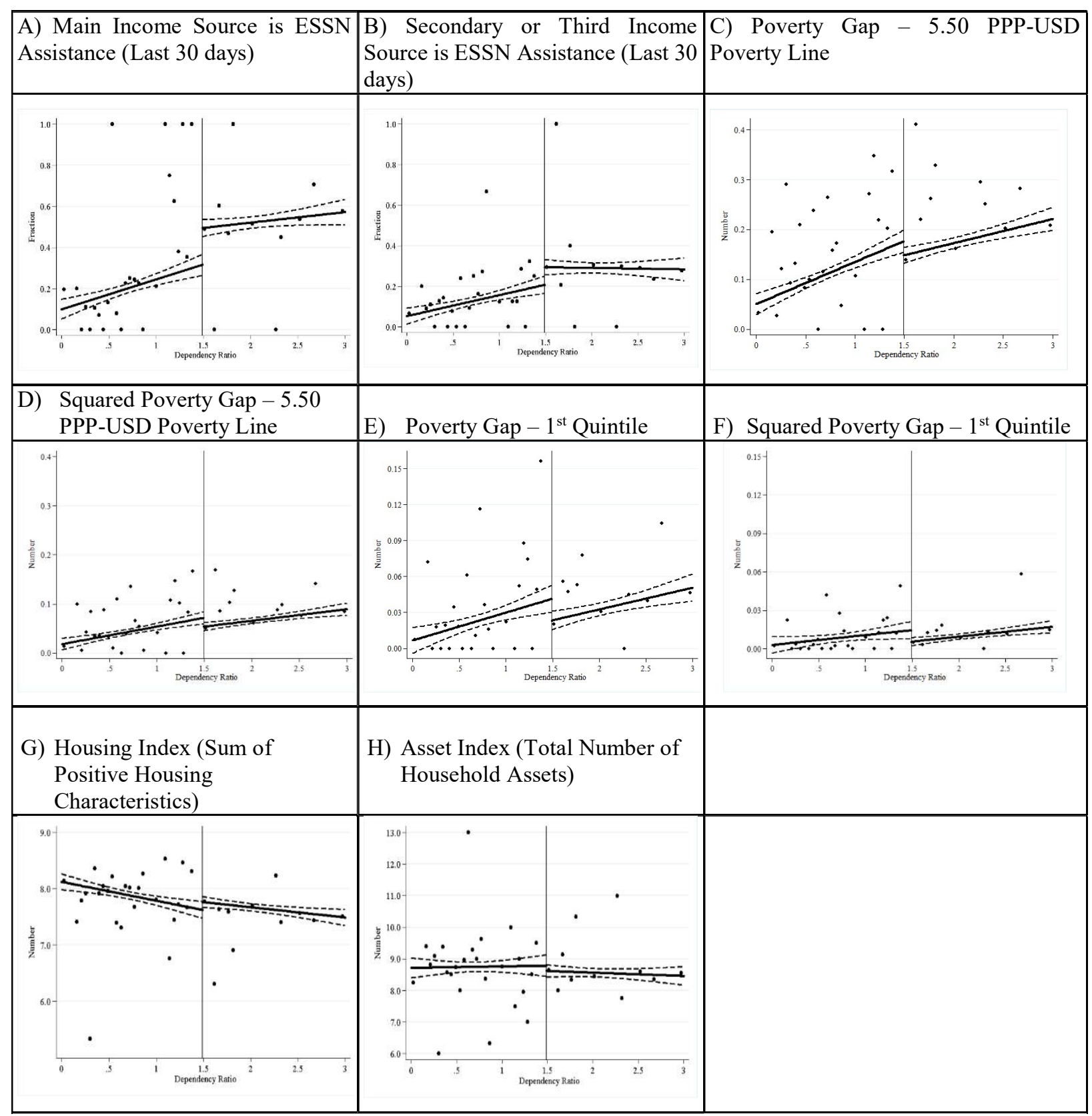

Note: Panels C and D use World Bank's poverty line for upper-middle income countries; that is, $\$ 5.50$ per day in PPPadjusted terms. Panels E and F use an extreme poverty line defined as the consumption level of the first quintile of consumption in the CVME3 (2779 TL/year). 
Figure 4: The Effect of Dependency-Ratio Criterion on Consumption, Coping Mechanisms, and Child Health

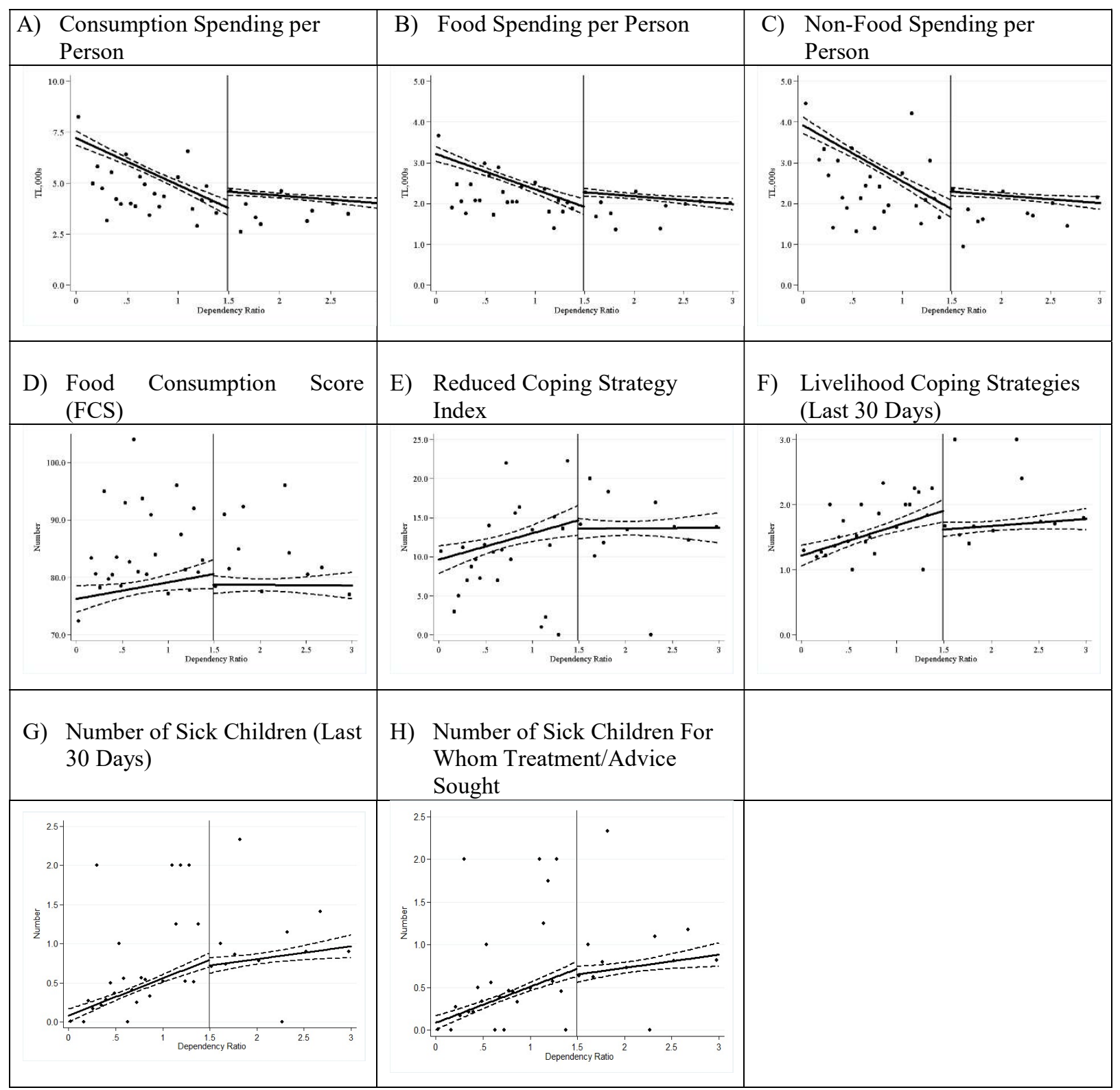

Note: Food Consumption Score is an indicator of the frequency of various food items consumed in the previous 7 days. Reduced Coping Strategy Index is an index that reflects the frequency of certain types of harmful coping behaviors in the previous 7 days when a family lacks food. The Livelihood Coping Strategy index aggregates 13 harmful behaviors related to income and livelihood to cope with insufficient money for meeting basic needs in the previous 30 days. 
Figure 5: The Effect of Dependency-Ratio Criterion on Reasons for Children Not Attending School and Other Outcomes on Child Labor and Schooling

\begin{tabular}{|l|l|l|l|}
\hline A) Children Need to Work & B) Children Need to Stay Home and Assist Family \\
\hline & & & \\
\hline
\end{tabular}




\begin{tabular}{|c|c|c|c|c|c|}
\hline & Mean & S.D. & Min. & Max. & No obs. \\
\hline Beneficiary household & 0.516 & 0.500 & 0 & 1 & 2681 \\
\hline Number of boys under 18 who worked in the last 30 days & 0.155 & 0.437 & 0 & 3 & 2681 \\
\hline Number of girls under 18 who worked in the last 30 days & 0.038 & 0.238 & 0 & 3 & 2681 \\
\hline Share of boys under 18 who worked in the last 30 days & 0.084 & 0.247 & 0 & 1 & 2681 \\
\hline Share of girls under 18 who worked in the last 30 days & 0.018 & 0.118 & 0 & 1 & 2681 \\
\hline Number of boys aged 6-17 who did not attend school last semester & 0.332 & 0.707 & 0 & 6 & 2681 \\
\hline Number of girls aged 6-17 who did not attend school last semester & 0.316 & 0.760 & 0 & 8 & 2681 \\
\hline Share of boys aged 6-17 who did not attend school last semester & 0.188 & 0.366 & 0 & 1 & 2681 \\
\hline Share of girls aged 6-17 who did not attend school last semester & 0.166 & 0.351 & 0 & 1 & 2681 \\
\hline \multicolumn{6}{|l|}{ Income, Poverty, Assets and Housing } \\
\hline Main Income Source is WFP/TRC Assistance (last 30 days) & 0.393 & 0.489 & 0 & 1 & 2681 \\
\hline Secondary or Third Income Source is WFP/TRC Assistance (last 30 days) & 0.208 & 0.406 & 0 & 1 & 2681 \\
\hline Poverty Gap -5.5 USD PPP Line & 0.151 & 0.191 & 0 & 1 & 2681 \\
\hline Squared Poverty Gap - Poverty Gap -5.5 USD PPP Line & 0.059 & 0.104 & 0 & 1 & 2681 \\
\hline Poverty Gap - Relative Poverty Line (1st Quintile of Consumption) & 0.031 & 0.096 & 0 & 1 & 2681 \\
\hline Squared Poverty Gap - Relative Poverty Line (1st Quintile of Consumption) & 0.010 & 0.049 & 0 & 1 & 2681 \\
\hline Housing Index (Sum of Positive Housing Characteristics) & 7.755 & 1.176 & 0.250 & 9.000 & 2681 \\
\hline Asset Index (Total Number of Household Assets) & 8.655 & 2.492 & 1 & 15 & 2681 \\
\hline \multicolumn{6}{|l|}{ Consumption, Coping Mechanism and Child Health } \\
\hline Annual Consumption Spending per Person (Top 1\% Censored, in thousands) & 4.897 & 2.611 & 0 & 18.631 & 2681 \\
\hline Annual Food Spending per Person (Top 1\% Censored, in thousands) & 2.359 & 1.362 & 0 & 9.297 & 2681 \\
\hline Annual Non-Food Spending per Person (Top 1\% Censored, in thousands) & 2.510 & 1.545 & 0 & 9.260 & 2681 \\
\hline Food Consumption Score (FCS) & 78.424 & 19.083 & 14 & 112 & 2681 \\
\hline Reduced Coping Strategy Index (0-56, the higher the worse) & 13.350 & 15.620 & 0 & 56 & 2681 \\
\hline Livelihood Coping Strategies (0-13, the higher the worse) (Last 30 Days) & 1.649 & 1.346 & 0 & 9 & 2681 \\
\hline Number of Sick Children (Last 30 Days) & 0.659 & 1.067 & 0 & 10 & 2681 \\
\hline Number of Sick Children for Whom Treatment Sought (Last 30 Days) & 0.595 & 1.000 & 0 & 9 & 2681 \\
\hline \multicolumn{6}{|l|}{ Reasons for Children Not Attending School } \\
\hline Children need to work & 0.104 & 0.305 & 0 & 1 & 2681 \\
\hline Children need to stay home and assist family & 0.025 & 0.155 & 0 & 1 & 2681 \\
\hline Family cannot afford to pay school expenses & 0.041 & 0.198 & 0 & 1 & 2681 \\
\hline Children sick/unwell & 0.011 & 0.103 & 0 & 1 & 2681 \\
\hline
\end{tabular}

Notes: The data come from the rounds three and four of the Comprehensive Vulnerability Monitoring Exercise (CVME) of Turkey. The sample size is 1,301 in wave 3 and 1,380 in wave 4. 
Table 2: The Effect of Dependency-Ratio Criterion on Beneficiary Status and on Number of Children Working and Number of Children not in School by Gender

\begin{tabular}{|c|c|c|c|c|c|c|c|c|c|}
\hline$(1)$ & $(2)$ & (3) & (4) & $(5)$ & $(6)$ & $(7)$ & $(8)$ & $(9)$ & $(10)$ \\
\hline & Beneficiary & $\begin{array}{c}\text { Number } \\
\text { boys } \\
\text { working }\end{array}$ & $\begin{array}{c}\text { Number } \\
\text { girls } \\
\text { working }\end{array}$ & $\begin{array}{l}\text { Number } \\
\text { children } \\
\text { working }\end{array}$ & $\begin{array}{c}\text { Number } \\
\text { boys not in } \\
\text { school }\end{array}$ & $\begin{array}{c}\text { Number } \\
\text { girls not in } \\
\text { school }\end{array}$ & $\begin{array}{l}\text { Number } \\
\text { children not } \\
\text { in school }\end{array}$ & $\begin{array}{l}\text { No } \\
\text { obs. }\end{array}$ & $\begin{array}{c}\text { No. } \\
\text { cluster }\end{array}$ \\
\hline \multicolumn{10}{|l|}{ A) Baseline } \\
\hline Full Data & $\begin{array}{c}0.307 * * * \\
{[0.084]}\end{array}$ & $\begin{array}{c}-0.082 * * * \\
{[0.016]}\end{array}$ & $\begin{array}{c}-0.019 * * \\
{[0.010]}\end{array}$ & $\begin{array}{c}-0.096 * * * \\
{[0.017]}\end{array}$ & $\begin{array}{c}-0.121 * * * \\
{[0.039]}\end{array}$ & $\begin{array}{c}-0.088 * * * \\
{[0.029]}\end{array}$ & $\begin{array}{c}-0.207 * * * \\
{[0.055]}\end{array}$ & 2,681 & 56 \\
\hline $0<=\mathrm{DR}<=4.5$ & $\begin{array}{c}0.334 * * * \\
{[0.086]}\end{array}$ & $\begin{array}{c}-0.075 * * * \\
{[0.016]}\end{array}$ & $\begin{array}{c}-0.020 * * \\
{[0.010]}\end{array}$ & $\begin{array}{c}-0.086 * * * \\
{[0.017]}\end{array}$ & $\begin{array}{c}-0.129 * * * \\
{[0.038]}\end{array}$ & $\begin{array}{c}-0.106 * * * \\
{[0.028]}\end{array}$ & $\begin{array}{c}-0.217 * * * \\
{[0.057]}\end{array}$ & 2,589 & 51 \\
\hline $0<=\mathrm{DR}<=3.5$ & $\begin{array}{c}0.356^{* * *} \\
{[0.083]}\end{array}$ & $\begin{array}{c}-0.084 * * * \\
{[0.014]}\end{array}$ & $\begin{array}{c}-0.016 \\
{[0.010]}\end{array}$ & $\begin{array}{c}-0.090 * * * \\
{[0.017]}\end{array}$ & $\begin{array}{c}-0.123 * * * \\
{[0.039]}\end{array}$ & $\begin{array}{c}-0.091 * * * \\
{[0.032]}\end{array}$ & $\begin{array}{c}-0.193 * * * \\
{[0.066]}\end{array}$ & 2,510 & 48 \\
\hline $0<=\mathrm{DR}<=3.0$ & $\begin{array}{c}0.377 * * * \\
{[0.077]}\end{array}$ & $\begin{array}{c}-0.076 * * * \\
{[0.015]}\end{array}$ & $\begin{array}{c}-0.019 * * \\
{[0.009]}\end{array}$ & $\begin{array}{c}-0.089 * * * \\
{[0.017]}\end{array}$ & $\begin{array}{c}-0.108 * * \\
{[0.043]}\end{array}$ & $\begin{array}{c}-0.086^{* *} \\
{[0.033]}\end{array}$ & $\begin{array}{c}-0.176 * * \\
{[0.072]}\end{array}$ & 2,448 & 45 \\
\hline $0.5<=\mathrm{DR}<=2.5$ & $\begin{array}{c}0.350 * * * \\
{[0.084]}\end{array}$ & $\begin{array}{c}-0.058^{* *} \\
{[0.027]}\end{array}$ & $\begin{array}{c}-0.013 \\
{[0.010]}\end{array}$ & $\begin{array}{c}-0.068^{* *} \\
{[0.025]}\end{array}$ & $\begin{array}{c}-0.112 * * \\
{[0.053]}\end{array}$ & $\begin{array}{c}-0.083 * * \\
{[0.034]}\end{array}$ & $\begin{array}{c}-0.179 * * \\
{[0.072]}\end{array}$ & 2,036 & 32 \\
\hline \multicolumn{10}{|l|}{ B) Full Controls } \\
\hline Full Data & $\begin{array}{c}0.318^{* * *} \\
{[0.073]}\end{array}$ & $\begin{array}{c}-0.075 * * * \\
{[0.013]}\end{array}$ & $\begin{array}{c}-0.015 \\
{[0.011]}\end{array}$ & $\begin{array}{c}-0.086^{* * *} \\
{[0.019]}\end{array}$ & $\begin{array}{c}-0.117 * * * \\
{[0.043]}\end{array}$ & $\begin{array}{c}-0.071 \\
{[0.045]}\end{array}$ & $\begin{array}{c}-0.190 * * * \\
{[0.071]}\end{array}$ & 2,681 & 56 \\
\hline $0<=\mathrm{DR}<=4.5$ & $\begin{array}{c}0.346^{* * *} \\
{[0.073]}\end{array}$ & $\begin{array}{c}-0.070 * * * \\
{[0.012]}\end{array}$ & $\begin{array}{c}-0.017 \\
{[0.011]}\end{array}$ & $\begin{array}{c}-0.084 * * * \\
{[0.018]}\end{array}$ & $\begin{array}{c}-0.125 * * * \\
{[0.041]}\end{array}$ & $\begin{array}{c}-0.094 * * \\
{[0.045]}\end{array}$ & $\begin{array}{c}-0.211 * * * \\
{[0.073]}\end{array}$ & 2,589 & 51 \\
\hline $0<=\mathrm{DR}<=3.5$ & $\begin{array}{c}0.376 * * * \\
{[0.066]}\end{array}$ & $\begin{array}{c}-0.080^{* * *} \\
{[0.011]}\end{array}$ & $\begin{array}{c}-0.014 \\
{[0.010]}\end{array}$ & $\begin{array}{c}-0.092 * * * \\
{[0.016]}\end{array}$ & $\begin{array}{c}-0.124 * * * \\
{[0.041]}\end{array}$ & $\begin{array}{c}-0.082 * \\
{[0.046]}\end{array}$ & $\begin{array}{c}-0.202 * * * \\
{[0.074]}\end{array}$ & 2,510 & 48 \\
\hline $0<=\mathrm{DR}<=3.0$ & $\begin{array}{c}0.389 * * * \\
{[0.064]}\end{array}$ & $\begin{array}{c}-0.072 * * * \\
{[0.011]}\end{array}$ & $\begin{array}{c}-0.017 * \\
{[0.010]}\end{array}$ & $\begin{array}{c}-0.090 * * * \\
{[0.017]}\end{array}$ & $\begin{array}{c}-0.111 * * \\
{[0.043]}\end{array}$ & $\begin{array}{c}-0.081 * \\
{[0.044]}\end{array}$ & $\begin{array}{c}-0.191 * * \\
{[0.079]}\end{array}$ & 2,448 & 45 \\
\hline $0.5<=\mathrm{DR}<=2.5$ & $\begin{array}{c}0.371 * * * \\
{[0.074]}\end{array}$ & $\begin{array}{c}-0.050 * * \\
{[0.020]}\end{array}$ & $\begin{array}{c}-0.012 \\
{[0.014]}\end{array}$ & $\begin{array}{c}-0.072 * * \\
{[0.026]}\end{array}$ & $\begin{array}{c}-0.123 * * \\
{[0.052]}\end{array}$ & $\begin{array}{c}-0.083^{*} \\
{[0.046]}\end{array}$ & $\begin{array}{c}-0.230 * * * \\
{[0.069]}\end{array}$ & 2,036 & 32 \\
\hline
\end{tabular}

Notes: "DR" stands for dependency ratio. The data come from the rounds three and four of the Comprehensive Vulnerability Monitoring Exercise (CVME) of Turkey. The sample is restricted to various bandwidths around the cutoff (dependency ratio=1.5) as given in column (1). The dependent variable is given in column headings (2) to (8). Each cell comes from a separate regression. All regressions include a control for the policy dummy and split linear polynomials around the cutoff in the running variable (dependency ratio). The baseline specification in panel (A), in addition, include a dummy variable for ESSN program eligibility via any of the five other eligibility criteria (single women, single parents with at least one child, elderly with no other adult in the household, families with at least four children, families with at least one disabled person with a report) in column (2), and dummy variables for different values of number of boys in columns (3) and (6), for different values of number of girls in columns (4) and (7) and for different values of number of children in columns (5) and (8). The full specification, in panel (B) also includes household characteristics including the number total household members, the number of children below age six, the number of children aged 6-17, dummies for household head's sex, education (illiterate, literate, primary/intermediate, secondary, technical, university), occupation before arrival (management/highly skilled, skilled worker, unskilled worker, retired, other), nationality (Afghan, Iraqi, Syrian, other), time of arrival (less than 6 months, 6 months-1 year, 1 year - 3 years, more than 3 years, before the conflict started), and 12 NUTS- 1 level regions in all columns. Panel (B) also adds the dummy variable for eligibility status via any other channel to columns (3) to (8). Clustering is done at the level of dependency ratio. Statistically significant: $* * * 1$ percent level; $* * 5$ percent level, * 10 percent level. 
Table 3: The Effect of Dependency-Ratio Criterion on Beneficiary Status and Shares of Children Working and not in School by Gender

\begin{tabular}{|c|c|c|c|c|c|c|c|c|c|}
\hline$(1)$ & $(2)$ & (3) & (4) & $(5)$ & $(6)$ & (7) & $(8)$ & $(9)$ & $(10)$ \\
\hline & Beneficiary & $\begin{array}{c}\text { Share of } \\
\text { boys } \\
\text { working }\end{array}$ & $\begin{array}{c}\text { Share of } \\
\text { girls } \\
\text { working }\end{array}$ & $\begin{array}{l}\text { Share of } \\
\text { children } \\
\text { working }\end{array}$ & $\begin{array}{c}\text { Share of } \\
\text { boys not in } \\
\text { school }\end{array}$ & $\begin{array}{l}\text { Share of } \\
\text { girls not } \\
\text { in school }\end{array}$ & $\begin{array}{c}\text { Share of } \\
\text { children not } \\
\text { in school }\end{array}$ & $\begin{array}{l}\text { No } \\
\text { obs. }\end{array}$ & $\begin{array}{c}\text { No. } \\
\text { cluster }\end{array}$ \\
\hline \multicolumn{10}{|l|}{ A) Baseline } \\
\hline Full Data & $\begin{array}{c}0.307 * * * \\
{[0.084]}\end{array}$ & $\begin{array}{c}-0.058 * * * \\
{[0.010]}\end{array}$ & $\begin{array}{c}-0.012 * * * \\
{[0.004]}\end{array}$ & $\begin{array}{c}-0.046^{* * *} \\
{[0.010]}\end{array}$ & $\begin{array}{c}-0.073 * * * \\
{[0.018]}\end{array}$ & $\begin{array}{c}-0.056^{* * * *} \\
{[0.011]}\end{array}$ & $\begin{array}{c}-0.085 * * * \\
{[0.020]}\end{array}$ & 2,681 & 56 \\
\hline $0<=\mathrm{DR}<=4.5$ & $\begin{array}{c}0.334 * * * \\
{[0.086]}\end{array}$ & $\begin{array}{c}-0.054 * * * \\
{[0.010]}\end{array}$ & $\begin{array}{c}-0.012 * * * \\
{[0.004]}\end{array}$ & $\begin{array}{c}-0.044 * * * \\
{[0.010]}\end{array}$ & $\begin{array}{c}-0.078 * * * \\
{[0.018]}\end{array}$ & $\begin{array}{c}-0.061 * * * \\
{[0.011]}\end{array}$ & $\begin{array}{c}-0.088 * * * \\
{[0.020]}\end{array}$ & 2,589 & 51 \\
\hline $0<=\mathrm{DR}<=3.5$ & $\begin{array}{c}0.356 * * * \\
{[0.083]}\end{array}$ & $\begin{array}{c}-0.057 * * * \\
{[0.009]}\end{array}$ & $\begin{array}{c}-0.011 * * \\
{[0.005]}\end{array}$ & $\begin{array}{c}-0.044 * * * \\
{[0.011]}\end{array}$ & $\begin{array}{c}-0.075 * * * \\
{[0.019]}\end{array}$ & $\begin{array}{c}-0.060 * * * \\
{[0.011]}\end{array}$ & $\begin{array}{c}-0.084 * * * \\
{[0.021]}\end{array}$ & 2,510 & 48 \\
\hline $0<=\mathrm{DR}<=3.0$ & $\begin{array}{c}0.377 * * * \\
{[0.077]}\end{array}$ & $\begin{array}{c}-0.054 * * * \\
{[0.010]}\end{array}$ & $\begin{array}{c}-0.013 * * * \\
{[0.004]}\end{array}$ & $\begin{array}{c}-0.044 * * * \\
{[0.011]}\end{array}$ & $\begin{array}{c}-0.069 * * * \\
{[0.021]}\end{array}$ & $\begin{array}{c}-0.056 * * * \\
{[0.012]}\end{array}$ & $\begin{array}{c}-0.080 * * * \\
{[0.023]}\end{array}$ & 2,448 & 45 \\
\hline $0.5<=\mathrm{DR}<=2.5$ & $\begin{array}{c}0.350 * * * \\
{[0.084]}\end{array}$ & $\begin{array}{c}-0.041 * * \\
{[0.016]}\end{array}$ & $\begin{array}{c}-0.007 \\
{[0.005]}\end{array}$ & $\begin{array}{c}-0.033 * * \\
{[0.013]}\end{array}$ & $\begin{array}{c}-0.067 * * \\
{[0.026]}\end{array}$ & $\begin{array}{c}-0.046 * * * \\
{[0.016]} \\
\end{array}$ & $\begin{array}{c}-0.064 * * \\
{[0.024]}\end{array}$ & 2,036 & 32 \\
\hline \multicolumn{10}{|l|}{ B) Full Controls } \\
\hline Full Data & $\begin{array}{c}0.318 * * * \\
{[0.073]}\end{array}$ & $\begin{array}{c}-0.057 * * * \\
{[0.009]}\end{array}$ & $\begin{array}{c}-0.010 * \\
{[0.005]}\end{array}$ & $\begin{array}{c}-0.046^{* * *} \\
{[0.011]}\end{array}$ & $\begin{array}{c}-0.071 * * * \\
{[0.019]}\end{array}$ & $\begin{array}{c}-0.050 * * * \\
{[0.017]}\end{array}$ & $\begin{array}{c}-0.082 * * * \\
{[0.020]}\end{array}$ & 2,681 & 56 \\
\hline $0<=\mathrm{DR}<=4.5$ & $\begin{array}{c}0.346 * * * \\
{[0.073]}\end{array}$ & $\begin{array}{c}-0.055^{* * *} * \\
{[0.009]}\end{array}$ & $\begin{array}{c}-0.011 * * \\
{[0.005]}\end{array}$ & $\begin{array}{c}-0.047 * * * \\
{[0.011]}\end{array}$ & $\begin{array}{c}-0.075 * * * \\
{[0.018]}\end{array}$ & $\begin{array}{c}-0.056 * * * \\
{[0.017]}\end{array}$ & $\begin{array}{c}-0.088 * * * \\
{[0.020]}\end{array}$ & 2,589 & 51 \\
\hline $0<=\mathrm{DR}<=3.5$ & $\begin{array}{c}0.376 * * * \\
{[0.066]}\end{array}$ & $\begin{array}{c}-0.058 * * * \\
{[0.008]}\end{array}$ & $\begin{array}{c}-0.011 * * \\
{[0.005]}\end{array}$ & $\begin{array}{c}-0.048 * * * \\
{[0.010]}\end{array}$ & $\begin{array}{c}-0.075 * * * \\
{[0.018]}\end{array}$ & $\begin{array}{c}-0.059 * * * \\
{[0.015]}\end{array}$ & $\begin{array}{c}-0.090 * * * \\
{[0.019]}\end{array}$ & 2,510 & 48 \\
\hline $0<=\mathrm{DR}<=3.0$ & $\begin{array}{c}0.389 * * * \\
{[0.064]}\end{array}$ & $\begin{array}{c}-0.057 * * * \\
{[0.009]}\end{array}$ & $\begin{array}{c}-0.012 * * * \\
{[0.005]}\end{array}$ & $\begin{array}{c}-0.048 * * * \\
{[0.011]}\end{array}$ & $\begin{array}{c}-0.070 * * * \\
{[0.019]}\end{array}$ & $\begin{array}{c}-0.057 * * * \\
{[0.016]}\end{array}$ & $\begin{array}{c}-0.087 * * * \\
{[0.021]}\end{array}$ & 2,448 & 45 \\
\hline $0.5<=\mathrm{DR}<=2.5$ & $\begin{array}{c}0.371 * * * \\
{[0.074]}\end{array}$ & $\begin{array}{c}-0.043 * * * \\
{[0.014]} \\
\end{array}$ & $\begin{array}{c}-0.007 \\
{[0.006]}\end{array}$ & $\begin{array}{c}-0.039 * * * \\
{[0.013]}\end{array}$ & $\begin{array}{c}-0.070 * * \\
{[0.027]}\end{array}$ & $\begin{array}{c}-0.048 * * \\
{[0.022]}\end{array}$ & $\begin{array}{c}-0.078 * * * \\
{[0.023]}\end{array}$ & 2,036 & 32 \\
\hline
\end{tabular}

Notes: "DR" stands for dependency ratio. The data come from the rounds three and four of the Comprehensive Vulnerability Monitoring Exercise (CVME) of Turkey. The sample is restricted to various bandwidths around the cutoff (dependency ratio=1.5) as given in column (1). The dependent variable is given in column headings (2) to (8). Each cell comes from a separate regression. All regressions include a control for the policy dummy and split linear polynomials around the cutoff in the running variable (dependency ratio). The baseline specification in panel (A), in addition, include a dummy variable for ESSN program eligibility via any of the five other eligibility criteria (single women, single parents with at least one child, elderly with no other adult in the household, families with at least four children, families with at least one disabled person with a report) in column (2), and dummy variables for different values of number of boys in columns (3) and (6), for different values of number of girls in columns (4) and (7) and for different values of number of children in columns (5) and (8). The full specification, in panel (B) also includes household characteristics including the number total household members, the number of children below age six, the number of children aged 6-17, dummies for household head's sex, education (illiterate, literate, primary/intermediate, secondary, technical, university), occupation before arrival (management/highly skilled, skilled worker, unskilled worker, retired, other), nationality (Afghan, Iraqi, Syrian, other), time of arrival (less than 6 months, 6 months-1 year, 1 year - 3 years, more than 3 years, before the conflict started), 12 NUTS-1 level regions in all columns, and a dummy variable for ESSN eligibility status based on any other criteria (single women, single parents with at least one child, elderly with no other adult in the household, families with at least four children, families with at least one disabled person with a report). Clustering is done at the level of dependency ratio. Statistically significant: *** 1 percent level; ** 5 percent level, * 10 percent level. 
Table 4: The Effect of Dependency-Ratio Criterion on Number of Children Working and Number of Children not in School - Local Polynomial Approach with Baseline Variables

\begin{tabular}{|c|c|c|c|c|c|c|c|}
\hline$(1)$ & $(2)$ & (3) & (4) & (5) & (6) & $(7)$ & $(8)$ \\
\hline & Beneficiary & $\begin{array}{c}\text { Number } \\
\text { boys } \\
\text { working }\end{array}$ & $\begin{array}{c}\text { Number } \\
\text { girls } \\
\text { working }\end{array}$ & $\begin{array}{l}\text { Number } \\
\text { children } \\
\text { working }\end{array}$ & $\begin{array}{c}\text { Number } \\
\text { boys not in } \\
\text { school }\end{array}$ & $\begin{array}{c}\text { Number } \\
\text { girls not in } \\
\text { school }\end{array}$ & $\begin{array}{l}\text { Number } \\
\text { children not } \\
\text { in school }\end{array}$ \\
\hline \multicolumn{8}{|l|}{ A) IK Bandwidths } \\
\hline Bandwidth $=\mathrm{b}$ & $\begin{array}{c}0.331 * * * \\
(0.066)\end{array}$ & $\begin{array}{c}-0.088 * * * \\
(0.027)\end{array}$ & $\begin{array}{l}-0.000 \\
(0.017)\end{array}$ & $\begin{array}{l}-0.069^{*} \\
(0.036)\end{array}$ & $\begin{array}{c}-0.117 * * \\
(0.054)\end{array}$ & $\begin{array}{l}-0.108^{*} \\
(0.065)\end{array}$ & $\begin{array}{c}-0.210 * * * \\
(0.066)\end{array}$ \\
\hline Bandwidth $=b / 2$ & $\begin{array}{c}0.550^{* * * *} \\
(0.089)\end{array}$ & $\begin{array}{c}-0.123 * * * \\
(0.038)\end{array}$ & $\begin{array}{l}-0.010 \\
(0.060)\end{array}$ & $\begin{array}{l}-0.183 \\
(0.131)\end{array}$ & $\begin{array}{l}-0.131 \\
(0.131)\end{array}$ & $\begin{array}{l}0.276^{*} \\
(0.152)\end{array}$ & $\begin{array}{c}-0.267 * * \\
(0.126)\end{array}$ \\
\hline Bandwidth $=3 \mathrm{~b} / 2$ & $\begin{array}{c}0.410^{* * * *} \\
(0.082)\end{array}$ & $\begin{array}{c}-0.066^{* *} \\
(0.034)\end{array}$ & $\begin{array}{l}-0.013 \\
(0.012)\end{array}$ & $\begin{array}{c}-0.071 * * * \\
(0.025)\end{array}$ & $\begin{array}{c}-0.108^{* *} \\
(0.044)\end{array}$ & $\begin{array}{c}-0.087 * * \\
(0.036)\end{array}$ & $\begin{array}{c}-0.188 * * * \\
(0.072)\end{array}$ \\
\hline Bandwidth $=2 b$ & $\begin{array}{c}0.418^{* * *} \\
(0.083)\end{array}$ & $\begin{array}{c}-0.053^{* *} \\
(0.025)\end{array}$ & $\begin{array}{c}-0.021^{* *} \\
(0.009)\end{array}$ & $\begin{array}{c}-0.072 * * * \\
(0.025)\end{array}$ & $\begin{array}{c}-0.123^{* * *} \\
(0.041)\end{array}$ & $\begin{array}{c}-0.090 * * \\
(0.036)\end{array}$ & $\begin{array}{c}-0.202 * * * \\
(0.066)\end{array}$ \\
\hline Optimal Bandwidth (b) & 0.680 & 0.541 & 0.847 & 0.691 & 1.029 & 0.747 & 1.017 \\
\hline \multicolumn{8}{|l|}{ B) CCFT Bandwidths } \\
\hline Conventional & $\begin{array}{c}0.404 * * * \\
(0.000)\end{array}$ & $\begin{array}{c}-0.056 * * * \\
(0.007)\end{array}$ & $\begin{array}{l}-0.046 \\
(0.086)\end{array}$ & $\begin{array}{c}-0.049 * * * \\
(0.009)\end{array}$ & $\begin{array}{c}-0.108^{* * *} \\
(0.011)\end{array}$ & $\begin{array}{c}-0.114 * * * \\
(0.010)\end{array}$ & $\begin{array}{c}-0.188 * * * \\
(0.015)\end{array}$ \\
\hline Bias-corrected & $\begin{array}{c}0.394 * * * \\
(0.000)\end{array}$ & $\begin{array}{c}-0.054 * * * \\
(0.007)\end{array}$ & $\begin{array}{l}-0.024 \\
(0.086)\end{array}$ & $\begin{array}{c}-0.035^{* * *} \\
(0.009)\end{array}$ & $\begin{array}{c}-0.104 * * * \\
(0.011)\end{array}$ & $\begin{array}{c}-0.105^{* * *} \\
(0.010)\end{array}$ & $\begin{array}{c}-0.177 * * * \\
(0.015)\end{array}$ \\
\hline Robust & $\begin{array}{c}0.394 * * * \\
(0.001)\end{array}$ & $\begin{array}{c}-0.054 * * * \\
(0.014)\end{array}$ & $\begin{array}{l}-0.024 \\
(0.098)\end{array}$ & $\begin{array}{c}-0.035 * * * \\
(0.012)\end{array}$ & $\begin{array}{c}-0.104 * * * \\
(0.026)\end{array}$ & $\begin{array}{c}-0.105^{* * *} \\
(0.013)\end{array}$ & $\begin{array}{c}-0.177 * * * \\
(0.033)\end{array}$ \\
\hline $\begin{array}{l}\text { BW loc. poly. } \\
\text { BW bias }\end{array}$ & $\begin{array}{l}0.208 \\
0.999\end{array}$ & $\begin{array}{l}1.065 \\
1.235\end{array}$ & $\begin{array}{l}0.292 \\
0.684\end{array}$ & $\begin{array}{l}0.924 \\
1.593\end{array}$ & $\begin{array}{l}1.801 \\
2.567\end{array}$ & $\begin{array}{l}0.857 \\
1.414\end{array}$ & $\begin{array}{l}1.582 \\
2.096\end{array}$ \\
\hline
\end{tabular}

Notes: The data come from the rounds three and four of the Comprehensive Vulnerability Monitoring Exercise (CVME) of Turkey. The dependent variable in column (2) is the residual of beneficiary status after regressing it on the dummy variable for ESSN program eligibility via any of the five other eligibility criteria (single women, single parents with at least one child, elderly with no other adult in the household, families with at least four children, families with at least one disabled person with a report). The dependent variables in columns (3) to (8) are the residuals after regressing the dependent variable in column headings on dummies for the number of boys in columns (3) and (6), for the number of girls in colums (4) and (7), and for the number of children in coumns (5) and (8). Each cell comes from a separate regression. The number of observations is 2,681 in all regressions. In panel (A), local polynomial approach with Imbens-Kalyanaraman (IK) optimal bandwidths are used, which runs kernel regression models on both sides of the cutoff. In addition to the estimates with the optimal IK bandwidths, estimates with alternative bandwidths are provided. In panel (B), local polynomial approach to RDD of CCFT is used. In this method, MSE-optimal bandwidths that are set to be equal on both sides of the cutoff are taken. The order of local polynomial is one and the order of bias is two. In both panels, a uniform kernel is used. Clustering is done at the level of dependency ratio (except for column (4) in panel (B) due to convergence problems, where heteroskedasticity-robust standard errors are used instead). Statistically significant: *** 1 percent level; ** 5 percent level, * 10 percent level. 
Table 5: The Effect of Beneficiary Status on the Number and Share of Children Working and the Number and Share of Children not in School by Gender - Full Controls

\begin{tabular}{|c|c|c|c|c|c|c|c|c|}
\hline$(1)$ & (2) & (3) & (4) & (5) & (6) & $(7)$ & $(8)$ & (9) \\
\hline & $\begin{array}{c}\text { Number } \\
\text { boys } \\
\text { working }\end{array}$ & $\begin{array}{c}\text { Number } \\
\text { girls } \\
\text { working }\end{array}$ & $\begin{array}{l}\text { Number } \\
\text { children } \\
\text { working }\end{array}$ & $\begin{array}{l}\text { Number } \\
\text { boys not } \\
\text { in school }\end{array}$ & $\begin{array}{l}\text { Number } \\
\text { girls not } \\
\text { in school }\end{array}$ & $\begin{array}{c}\text { Number } \\
\text { children not } \\
\text { in school }\end{array}$ & $\begin{array}{l}\text { No } \\
\text { obs. }\end{array}$ & $\begin{array}{c}\text { No. } \\
\text { cluster }\end{array}$ \\
\hline Full Data & $\begin{array}{c}-0.236^{* * *} \\
{[0.055]}\end{array}$ & $\begin{array}{c}-0.047 \\
{[0.030]}\end{array}$ & $\begin{array}{c}-0.268^{* * *} \\
{[0.055]}\end{array}$ & $\begin{array}{c}-0.370 * * * \\
{[0.118]}\end{array}$ & $\begin{array}{l}-0.225^{*} \\
{[0.123]}\end{array}$ & $\begin{array}{c}-0.595^{* * *} \\
{[0.184]}\end{array}$ & 2,681 & 56 \\
\hline $0<=\mathrm{DR}<=4.5$ & $\begin{array}{c}-0.202 * * * \\
{[0.039]}\end{array}$ & $\begin{array}{l}-0.050^{*} \\
{[0.027]}\end{array}$ & $\begin{array}{c}-0.243 * * * \\
{[0.040]}\end{array}$ & $\begin{array}{c}-0.362 * * * \\
{[0.110]}\end{array}$ & $\begin{array}{c}-0.271^{* *} \\
{[0.119]}\end{array}$ & $\begin{array}{c}-0.610^{* * *} \\
{[0.188]}\end{array}$ & 2,589 & 51 \\
\hline $0<=\mathrm{DR}<=3.5$ & $\begin{array}{c}-0.212 * * * \\
{[0.042]}\end{array}$ & $\begin{array}{c}-0.038 \\
{[0.023]}\end{array}$ & $\begin{array}{c}-0.246 * * * \\
{[0.036]}\end{array}$ & $\begin{array}{c}-0.328 * * * \\
{[0.105]}\end{array}$ & $\begin{array}{c}-0.218^{* *} \\
{[0.107]}\end{array}$ & $\begin{array}{c}-0.539 * * * \\
{[0.178]}\end{array}$ & 2,510 & 48 \\
\hline $0<=\mathrm{DR}<=3.0$ & $\begin{array}{c}-0.185^{* * *} \\
{[0.031]}\end{array}$ & $\begin{array}{c}-0.044 * * \\
{[0.022]}\end{array}$ & $\begin{array}{c}-0.231 * * * \\
{[0.030]}\end{array}$ & $\begin{array}{c}-0.284 * * * \\
{[0.099]}\end{array}$ & $\begin{array}{c}-0.208^{* *} \\
{[0.102]}\end{array}$ & $\begin{array}{c}-0.493 * * * \\
{[0.180]}\end{array}$ & 2,448 & 45 \\
\hline \multirow[t]{2}{*}{$0.5<=\mathrm{DR}<=2.5$} & $\begin{array}{c}-0.133 * * * \\
{[0.047]} \\
\end{array}$ & $\begin{array}{c}-0.032 \\
{[0.033]}\end{array}$ & $\begin{array}{c}-0.193 * * * \\
{[0.052]} \\
\end{array}$ & $\begin{array}{c}-0.331 * * \\
{[0.138]} \\
\end{array}$ & $\begin{array}{l}-0.225^{*} \\
{[0.118]}\end{array}$ & $\begin{array}{c}-0.616^{* * *} \\
{[0.199]} \\
\end{array}$ & 2,036 & 32 \\
\hline & $\begin{array}{c}\text { Share of } \\
\text { boys } \\
\text { working }\end{array}$ & $\begin{array}{c}\text { Share of } \\
\text { girls } \\
\text { working }\end{array}$ & $\begin{array}{l}\text { Share of } \\
\text { children } \\
\text { working }\end{array}$ & $\begin{array}{l}\text { Share of } \\
\text { boys not } \\
\text { in school }\end{array}$ & $\begin{array}{l}\text { Share of } \\
\text { girls not } \\
\text { in school }\end{array}$ & $\begin{array}{l}\text { Share of } \\
\text { children not } \\
\text { in school }\end{array}$ & $\begin{array}{l}\text { No } \\
\text { obs. }\end{array}$ & $\begin{array}{c}\text { No. } \\
\text { cluster }\end{array}$ \\
\hline Full Data & $\begin{array}{c}-0.181^{* * *} \\
{[0.042]}\end{array}$ & $\begin{array}{c}-0.031 * * \\
{[0.014]}\end{array}$ & $\begin{array}{c}-0.146^{* * *} \\
{[0.024]}\end{array}$ & $\begin{array}{c}-0.223 * * * \\
{[0.056]}\end{array}$ & $\begin{array}{c}-0.158^{* * *} \\
{[0.054]}\end{array}$ & $\begin{array}{c}-0.258^{* * *} \\
{[0.053]}\end{array}$ & 2,681 & 56 \\
\hline $0<=\mathrm{DR}<=4.5$ & $\begin{array}{c}-0.159 * * * \\
{[0.032]}\end{array}$ & $\begin{array}{c}-0.033^{* * *} \\
{[0.012]}\end{array}$ & $\begin{array}{c}-0.135^{* * *} \\
{[0.020]}\end{array}$ & $\begin{array}{c}-0.217 * * * \\
{[0.054]}\end{array}$ & $\begin{array}{c}-0.163^{* * *} \\
{[0.049]}\end{array}$ & $\begin{array}{c}-0.255^{* * *} \\
{[0.052]}\end{array}$ & 2,589 & 51 \\
\hline $0<=\mathrm{DR}<=3.5$ & $\begin{array}{c}-0.155^{* * *} \\
{[0.028]}\end{array}$ & $\begin{array}{c}-0.029 * * * \\
{[0.010]}\end{array}$ & $\begin{array}{c}-0.129 * * * \\
{[0.018]}\end{array}$ & $\begin{array}{c}-0.199 * * * \\
{[0.050]}\end{array}$ & $\begin{array}{c}-0.157^{* * *} \\
{[0.043]}\end{array}$ & $\begin{array}{c}-0.239 * * * \\
{[0.048]}\end{array}$ & 2,510 & 48 \\
\hline $0<=\mathrm{DR}<=3.0$ & $\begin{array}{c}-0.146 * * * \\
{[0.024]}\end{array}$ & $\begin{array}{c}-0.031 * * * \\
{[0.010]}\end{array}$ & $\begin{array}{c}-0.123 * * * \\
{[0.016]}\end{array}$ & $\begin{array}{c}-0.181 * * * \\
{[0.046]}\end{array}$ & $\begin{array}{c}-0.146^{* * *} \\
{[0.041]}\end{array}$ & $\begin{array}{c}-0.224 * * * \\
{[0.047]}\end{array}$ & 2,448 & 45 \\
\hline $0.5<=\mathrm{DR}<=2.5$ & $\begin{array}{c}-0.116^{* * *} \\
{[0.032]}\end{array}$ & $\begin{array}{c}-0.018 \\
{[0.015]}\end{array}$ & $\begin{array}{c}-0.103 * * * \\
{[0.019]}\end{array}$ & $\begin{array}{c}-0.187 * * \\
{[0.074]}\end{array}$ & $\begin{array}{c}-0.130 * * \\
{[0.061]}\end{array}$ & $\begin{array}{c}-0.208 * * * \\
{[0.063]}\end{array}$ & 2,036 & 32 \\
\hline
\end{tabular}

Notes: "DR" stands for dependency ratio. The data come from the rounds three and four of the Comprehensive Vulnerability Monitoring Exercise (CVME) of Turkey. The sample is restricted to various bandwidths around the cutoff (dependency ratio=1.5) as given in column (1). The dependent variable is given in column headings (2) to (7). Each cell comes from a separate 2SLS regression, where beneficiary status is instrumented via treatment status in terms of dependency ratio. All regressions include a control for the policy dummy, split linear polynomials around the cutoff in the running variable (dependency ratio), a dummy variable for eligibility status via any other channel, household characteristics including the number total household members, the number of children below age six, the number of children aged 6-17, dummies for household head's sex, education (illiterate, literate, primary/intermediate, secondary, technical, university), occupation before arrival (management/highly skilled, skilled worker, unskilled worker, retired, other), nationality (Afghan, Iraqi, Syrian, other), time of arrival (less than 6 months, 6 months-1 year, 1 year - 3 years, more than 3 years, before the conflict started), and 12 NUTS-1 level regions in all columns. The covariates also include dummy variables for different values of number of boys in columns (2) and (5), for different values of number of girls in columns (3) and (6) and for different values of number of children in columns (4) and (7). Clustering is done at the level of dependency ratio. Statistically significant: *** 1 percent level; ** 5 percent level, * 10 percent level. 
Table 6: The Effect of Beneficiary Status on Income, Poverty, and Asset and Housing Indices

\begin{tabular}{|c|c|c|c|c|c|c|c|c|c|}
\hline$(1)$ & $(2)$ & (3) & (4) & $(5)$ & (6) & (7) & (8) & (9) & (10) \\
\hline & $\begin{array}{c}\text { Main } \\
\text { Income } \\
\text { Source is } \\
\text { WFP/TRC } \\
\text { Assistance }\end{array}$ & $\begin{array}{l}\text { Secondary } \\
\text { or Third } \\
\text { Income } \\
\text { Source is } \\
\text { WFP/TRC } \\
\text { Assistance }\end{array}$ & $\begin{array}{c}\text { Poverty } \\
\text { Gap } \\
5.50 \\
\text { PPP-USD } \\
\text { Poverty } \\
\text { Line } \\
\end{array}$ & $\begin{array}{c}\text { Squared } \\
\text { Poverty } \\
\text { Gap 5.50 } \\
\text { PPP USD } \\
\text { Poverty } \\
\text { Line }\end{array}$ & $\begin{array}{c}\text { Poverty } \\
\text { Gap } \\
-1 \text { st } \\
\text { Quintile } \\
\text { Poverty } \\
\text { Line } \\
\end{array}$ & $\begin{array}{c}\text { Poverty } \\
\text { Gap } \\
-1 \text { st } \\
\text { Quintile } \\
\text { Poverty } \\
\text { Line }\end{array}$ & $\begin{array}{c}\text { Housing } \\
\text { index }\end{array}$ & $\begin{array}{c}\text { Total } \\
\text { Number of } \\
\text { Assets }\end{array}$ & $\begin{array}{l}\text { No } \\
\text { obs. }\end{array}$ \\
\hline Full Data & $\begin{array}{c}0.529 * * * \\
{[0.065]}\end{array}$ & $\begin{array}{c}0.319 * * * \\
{[0.039]}\end{array}$ & $\begin{array}{c}-0.003 \\
{[0.045]}\end{array}$ & $\begin{array}{c}-0.023 \\
{[0.024]}\end{array}$ & $\begin{array}{c}-0.040 * \\
{[0.021]}\end{array}$ & $\begin{array}{c}-0.022 * * * \\
{[0.006]}\end{array}$ & $\begin{array}{c}-0.046 \\
{[0.198]}\end{array}$ & $\begin{array}{c}-0.641 \\
{[0.428]}\end{array}$ & 2,681 \\
\hline $0<=\mathrm{DR}<=4.5$ & $\begin{array}{c}0.498 * * * \\
{[0.067]}\end{array}$ & $\begin{array}{c}0.334 * * * \\
{[0.042]}\end{array}$ & $\begin{array}{c}0.009 \\
{[0.040]}\end{array}$ & $\begin{array}{c}-0.016 \\
{[0.020]}\end{array}$ & $\begin{array}{c}-0.034 * * \\
{[0.017]}\end{array}$ & $\begin{array}{c}-0.021 * * * \\
{[0.004]}\end{array}$ & $\begin{array}{c}0.032 \\
{[0.160]}\end{array}$ & $\begin{array}{c}-0.554 \\
{[0.408]}\end{array}$ & 2,589 \\
\hline $0<=\mathrm{DR}<=3.5$ & $\begin{array}{c}0.517 * * * \\
{[0.057]}\end{array}$ & $\begin{array}{c}0.304 * * * \\
{[0.043]}\end{array}$ & $\begin{array}{c}-0.007 \\
{[0.040]}\end{array}$ & $\begin{array}{c}-0.022 \\
{[0.020]}\end{array}$ & $\begin{array}{c}-0.036 * * \\
{[0.016]}\end{array}$ & $\begin{array}{c}-0.021 * * * \\
{[0.004]}\end{array}$ & $\begin{array}{c}0.086 \\
{[0.134]}\end{array}$ & $\begin{array}{c}-0.468 \\
{[0.402]}\end{array}$ & 2,510 \\
\hline $0<=\mathrm{DR}<=3.0$ & $\begin{array}{c}0.522 * * * \\
{[0.057]}\end{array}$ & $\begin{array}{c}0.304 * * * \\
{[0.045]}\end{array}$ & $\begin{array}{c}-0.007 \\
{[0.038]}\end{array}$ & $\begin{array}{c}-0.020 \\
{[0.019]}\end{array}$ & $\begin{array}{c}-0.033 * * \\
{[0.015]}\end{array}$ & $\begin{array}{c}-0.021 * * * \\
{[0.004]}\end{array}$ & $\begin{array}{c}0.123 \\
{[0.116]}\end{array}$ & $\begin{array}{c}-0.438 \\
{[0.388]}\end{array}$ & 2,448 \\
\hline $0.5<=\mathrm{DR}<=2.5$ & $\begin{array}{c}0.498 * * * \\
{[0.075]}\end{array}$ & $\begin{array}{c}0.322 * * * \\
{[0.061]}\end{array}$ & $\begin{array}{c}-0.001 \\
{[0.059]}\end{array}$ & $\begin{array}{l}-0.018 \\
{[0.030]}\end{array}$ & $\begin{array}{c}-0.040 \\
{[0.025]}\end{array}$ & $\begin{array}{c}-0.019 * * * \\
{[0.006]}\end{array}$ & $\begin{array}{c}0.125 \\
{[0.159]}\end{array}$ & $\begin{array}{c}0.198 \\
{[0.547]}\end{array}$ & 2,036 \\
\hline
\end{tabular}

Notes: "DR" stands for dependency ratio. Columns (4) and (5) use World Bank's poverty line for upper-middle income countries; $\$ 5.50$ per day in PPP-adjusted terms. Columns (6) and (7) use an extreme poverty line defined as the consumption level of the first quintile of consumption in the CVME3 (2779 TL/year). Housing Index in (8) is the sum of positive housing characteristics. Column (9) uses total number of household assets. The data come from the rounds three and four of the Comprehensive Vulnerability Monitoring Exercise (CVME) of Turkey. The sample is restricted to various bandwidths around the cutoff (dependency ratio=1.5) as given in column (1). The dependent variable is given in column headings (2) to (7). Each cell comes from a separate regression. All regressions include a control for the policy dummy and split linear polynomials around the cutoff in the running variable (dependency ratio). They also include household characteristics including the number total household members, the number of children below age six, the number of children aged 6-17, dummies for household head's sex, education (illiterate, literate, primary/intermediate, secondary, technical, university), occupation before arrival (management/highly skilled, skilled worker, unskilled worker, retired, other), nationality (Afghan, Iraqi, Syrian, other), time of arrival (less than 6 months, 6 months-1 year, 1 year - 3 years, more than 3 years, before the conflict started), and 12 NUTS-1 level regions in all columns. Clustering is done at the level of dependency ratio. Statistically significant: *** 1 percent level; $* * 5$ percent level, $* 10$ percent level. 
Table 7: The Effect of Beneficiary Status on Consumption, Coping Mechanisms, and Child Health

\begin{tabular}{|c|c|c|c|c|c|c|c|c|c|}
\hline$(1)$ & $(2)$ & (3) & (4) & $(5)$ & (6) & $(7)$ & $(8)$ & $(9)$ & $(10)$ \\
\hline & $\begin{array}{c}\text { Consumption } \\
\text { Spending } \\
\text { per } \\
\text { Person } \\
\end{array}$ & $\begin{array}{c}\text { Food } \\
\text { Spending } \\
\text { per } \\
\text { Person } \\
\end{array}$ & $\begin{array}{l}\text { Non-Food } \\
\text { Spending } \\
\text { per } \\
\text { Person } \\
\end{array}$ & $\begin{array}{c}\text { Food } \\
\text { Consumption } \\
\text { Score } \\
\text { (FCS) } \\
\end{array}$ & $\begin{array}{l}\text { Reduced } \\
\text { Coping } \\
\text { Strategy } \\
\text { Index } \\
\end{array}$ & $\begin{array}{l}\text { Livelihood } \\
\text { Coping } \\
\text { Strategies } \\
\end{array}$ & $\begin{array}{l}\text { \# Sick } \\
\text { Children } \\
\text { (Last } \\
\text { 30 Days) }\end{array}$ & $\begin{array}{c}\text { \# Sick } \\
\text { Children } \\
\text { For Whom } \\
\text { Treatment } \\
\text { Sought } \\
\end{array}$ & $\begin{array}{l}\text { No } \\
\text { obs. }\end{array}$ \\
\hline Full Data & $\begin{array}{c}0.958 \\
{[0.717]}\end{array}$ & $\begin{array}{c}0.337 \\
{[0.292]}\end{array}$ & $\begin{array}{c}0.600 \\
{[0.404]}\end{array}$ & $\begin{array}{c}-0.413 \\
{[3.480]}\end{array}$ & $\begin{array}{c}-5.314^{* *} \\
{[2.400]}\end{array}$ & $\begin{array}{c}-0.717 * * * \\
{[0.278]}\end{array}$ & $\begin{array}{c}0.014 \\
{[0.231]}\end{array}$ & $\begin{array}{c}0.080 \\
{[0.253]}\end{array}$ & 2,681 \\
\hline $0<=\mathrm{DR}<=4.5$ & $\begin{array}{c}0.703 \\
{[0.651]}\end{array}$ & $\begin{array}{c}0.222 \\
{[0.262]}\end{array}$ & $\begin{array}{c}0.479 \\
{[0.376]}\end{array}$ & $\begin{array}{c}-0.493 \\
{[3.141]}\end{array}$ & $\begin{array}{c}-5.674 * * \\
{[2.658]}\end{array}$ & $\begin{array}{c}-0.771 * * * \\
{[0.297]}\end{array}$ & $\begin{array}{c}0.033 \\
{[0.218]}\end{array}$ & $\begin{array}{c}0.030 \\
{[0.229]}\end{array}$ & 2,589 \\
\hline $0<=\mathrm{DR}<=3.5$ & $\begin{array}{c}0.816 \\
{[0.604]}\end{array}$ & $\begin{array}{c}0.335 \\
{[0.233]}\end{array}$ & $\begin{array}{c}0.446 \\
{[0.351]}\end{array}$ & $\begin{array}{c}0.430 \\
{[2.563]}\end{array}$ & $\begin{array}{c}-4.677 * * \\
{[2.195]}\end{array}$ & $\begin{array}{c}-0.730 * * * \\
{[0.272]}\end{array}$ & $\begin{array}{c}0.041 \\
{[0.205]}\end{array}$ & $\begin{array}{c}0.053 \\
{[0.220]}\end{array}$ & 2,510 \\
\hline $0<=\mathrm{DR}<=3.0$ & $\begin{array}{c}0.832 \\
{[0.573]}\end{array}$ & $\begin{array}{c}0.349 \\
{[0.221]}\end{array}$ & $\begin{array}{c}0.448 \\
{[0.335]}\end{array}$ & $\begin{array}{c}0.076 \\
{[2.419]}\end{array}$ & $\begin{array}{c}-3.710 * * \\
{[1.653]}\end{array}$ & $\begin{array}{c}-0.656^{* * *} \\
{[0.229]}\end{array}$ & $\begin{array}{c}0.033 \\
{[0.189]}\end{array}$ & $\begin{array}{c}0.030 \\
{[0.204]}\end{array}$ & 2,448 \\
\hline $0.5<=\mathrm{DR}<=2.5$ & $\begin{array}{c}0.323 \\
{[0.473]} \\
\end{array}$ & $\begin{array}{c}0.340 \\
{[0.230]}\end{array}$ & $\begin{array}{c}-0.027 \\
{[0.263]}\end{array}$ & $\begin{array}{l}4.330^{*} \\
{[2.243]}\end{array}$ & $\begin{array}{c}-5.445^{* *} \\
{[2.285]}\end{array}$ & $\begin{array}{c}-0.967 * * * \\
{[0.290]}\end{array}$ & $\begin{array}{c}0.159 \\
{[0.272]}\end{array}$ & $\begin{array}{c}0.150 \\
{[0.288]}\end{array}$ & 2,036 \\
\hline
\end{tabular}

Notes: "DR" stands for dependency ratio. The data come from the rounds three and four of the Comprehensive Vulnerability Monitoring Exercise (CVME) of Turkey. The sample is restricted to various bandwidths around the cutoff (dependency ratio=1.5) as given in column (1). The dependent variable is given in column headings (2) to (7). Each cell comes from a separate regression. All regressions include a control for the policy dummy and split linear polynomials around the cutoff in the running variable (dependency ratio). They also include household characteristics including the number total household members, the number of children below age six, the number of children aged 6-17, dummies for household head's sex, education (illiterate, literate, primary/intermediate, secondary, technical, university), occupation before arrival (management/highly skilled, skilled worker, unskilled worker, retired, other), nationality (Afghan, Iraqi, Syrian, other), time of arrival (less than 6 months, 6 months-1 year, 1 year -3 years, more than 3 years, before the conflict started), and 12 NUTS-1 level regions in all columns. Clustering is done at the level of dependency ratio. Statistically significant: *** 1 percent level; ** 5 percent level, * 10 percent level. 
Table 8: The Effect of Beneficiary Status on not Attending School by Reason

\begin{tabular}{lccccc}
\hline & $(2)$ & $(3)$ & $(4)$ & $(5)$ & $(6)$ \\
\hline \multirow{7}{*}{$\begin{array}{c}\text { Children } \\
\text { need } \\
\text { to work }\end{array}$} & $\begin{array}{c}\text { Children } \\
\text { need to } \\
\text { assist family }\end{array}$ & $\begin{array}{c}\text { Family } \\
\text { cannot } \\
\text { afford }\end{array}$ & $\begin{array}{c}\text { Children } \\
\text { sick }\end{array}$ & No obs. \\
\hline Full Data & $-0.167^{* * *}$ & $-0.065^{* *}$ & -0.058 & -0.027 & 2,681 \\
& {$[0.037]$} & {$[0.031]$} & {$[0.040]$} & {$[0.033]$} & \\
$0<=$ DR $<=4.5$ & $-0.164^{* * *}$ & $-0.073^{* * *}$ & -0.054 & -0.017 & 2,589 \\
& {$[0.034]$} & {$[0.028]$} & {$[0.038]$} & {$[0.028]$} & \\
$0<=$ DR $<=3.5$ & $-0.165^{* * *}$ & $-0.063^{* * *}$ & $-0.062^{*}$ & -0.020 & 2,510 \\
& {$[0.036]$} & {$[0.023]$} & {$[0.035]$} & {$[0.027]$} & \\
$0<=\mathrm{DR}<=3.0$ & $-0.145^{* * *}$ & $-0.058^{* * *}$ & -0.056 & -0.027 & 2,448 \\
& {$[0.025]$} & {$[0.021]$} & {$[0.035]$} & {$[0.027]$} & \\
$0.5<=\mathrm{DR}<=2.5$ & $-0.079^{* *}$ & $-0.060^{* *}$ & -0.037 & -0.034 & 2,036 \\
& {$[0.034]$} & {$[0.026]$} & {$[0.050]$} & {$[0.038]$} & \\
\hline
\end{tabular}

Notes: "DR" stands for dependency ratio. The data come from the rounds three and four of the Comprehensive Vulnerability Monitoring Exercise (CVME) of Turkey. The sample is restricted to various bandwidths around the cutoff (dependency ratio=1.5) as given in column (1). The dependent variable is given in column headings (2) to (7). Each cell comes from a separate regression. All regressions include a control for the policy dummy and split linear polynomials around the cutoff in the running variable (dependency ratio). They also include household characteristics including the number total household members, the number of children below age six, the number of children aged 6-17, dummies for household head's sex, education (illiterate, literate, primary/intermediate, secondary, technical, university), occupation before arrival (management/highly skilled, skilled worker, unskilled worker, retired, other), nationality (Afghan, Iraqi, Syrian, other), time of arrival (less than 6 months, 6 months-1 year, 1 year - 3 years, more than 3 years, before the conflict started), and 12 NUTS-1 level regions in all columns. Clustering is done at the level of dependency ratio. Statistically significant: *** 1 percent level; ** 5 percent level, * 10 percent level. 
Table 9: Heterogeneity in the Effect of Beneficiary Status on the Share of Children Working and the Share of Children not in School by Gender

\begin{tabular}{|c|c|c|c|c|c|c|}
\hline$(1)$ & $(2)$ & $(3)$ & $(4)$ & $(5)$ & $(6)$ & $(7)$ \\
\hline & $\begin{array}{c}\text { Share of } \\
\text { boys } \\
\text { working }\end{array}$ & $\begin{array}{c}\text { Share of } \\
\text { girls } \\
\text { working }\end{array}$ & $\begin{array}{l}\text { Share of } \\
\text { children } \\
\text { working }\end{array}$ & $\begin{array}{c}\text { Share of } \\
\text { boys not in } \\
\text { school }\end{array}$ & $\begin{array}{c}\text { Share of } \\
\text { girls not in } \\
\text { school }\end{array}$ & $\begin{array}{c}\text { Share of } \\
\text { children not } \\
\text { in school }\end{array}$ \\
\hline \multicolumn{7}{|l|}{ A) Age of Children } \\
\hline 6-11 year old & $\begin{array}{l}-- \\
--\end{array}$ & $\begin{array}{l}-- \\
--\end{array}$ & $\begin{array}{l}-- \\
--\end{array}$ & $\begin{array}{c}-0.116^{* * *} \\
{[0.035]}\end{array}$ & $\begin{array}{c}-0.053 \\
{[0.040]}\end{array}$ & $\begin{array}{c}-0.127 * * \\
{[0.051]}\end{array}$ \\
\hline $12-17$ year old & -- & -- & -- & $\begin{array}{c}-0.125^{*} \\
{[0.069]} \\
\end{array}$ & $\begin{array}{c}-0.159^{* * *} \\
{[0.052]}\end{array}$ & $\begin{array}{c}-0.206^{* * *} \\
{[0.051]}\end{array}$ \\
\hline \multicolumn{7}{|l|}{ B) Education of Household Head } \\
\hline Illiterate or Literate with no degree & $\begin{array}{c}-0.259 * * * \\
{[0.061]}\end{array}$ & $\begin{array}{c}-0.071 * * * \\
{[0.024]}\end{array}$ & $\begin{array}{c}-0.224 * * * \\
{[0.038]}\end{array}$ & $\begin{array}{c}-0.226^{* *} \\
{[0.093]}\end{array}$ & $\begin{array}{c}-0.250 * * * \\
{[0.062]}\end{array}$ & $\begin{array}{c}-0.310^{* * *} \\
{[0.092]}\end{array}$ \\
\hline Primary/Middle/High/Technical & $\begin{array}{c}-0.113 * * \\
{[0.057]}\end{array}$ & $\begin{array}{c}-0.022 \\
{[0.016]}\end{array}$ & $\begin{array}{c}-0.085^{* * *} \\
{[0.024]}\end{array}$ & $\begin{array}{c}-0.187^{* *} \\
{[0.081]}\end{array}$ & $\begin{array}{c}-0.099 * \\
{[0.056]}\end{array}$ & $\begin{array}{c}-0.183^{* * *} \\
{[0.058]}\end{array}$ \\
\hline University & $\begin{array}{c}-0.026 \\
{[0.071]}\end{array}$ & $\begin{array}{c}0.007 \\
{[0.021]}\end{array}$ & $\begin{array}{c}-0.012 \\
{[0.060]}\end{array}$ & $\begin{array}{c}0.064 \\
{[0.146]}\end{array}$ & $\begin{array}{c}-0.020 \\
{[0.131]}\end{array}$ & $\begin{array}{c}0.020 \\
{[0.184]}\end{array}$ \\
\hline \multicolumn{7}{|l|}{ C) Per-capita Consumption Quintile } \\
\hline Quintile $=1$ & $\begin{array}{c}-0.428 * \\
{[0.256]}\end{array}$ & $\begin{array}{l}-0.085 \\
{[0.104]}\end{array}$ & $\begin{array}{c}-0.382 * * * \\
{[0.077]}\end{array}$ & $\begin{array}{c}-0.445^{*} \\
{[0.265]}\end{array}$ & $\begin{array}{c}-0.437 * * * \\
{[0.140]}\end{array}$ & $\begin{array}{c}-0.682 * * * \\
{[0.234]}\end{array}$ \\
\hline Quintile $=2$ & $\begin{array}{c}-0.050 \\
{[0.141]}\end{array}$ & $\begin{array}{c}0.028 \\
{[0.023]}\end{array}$ & $\begin{array}{c}0.068 \\
{[0.138]}\end{array}$ & $\begin{array}{c}-0.323 * * * \\
{[0.089]}\end{array}$ & $\begin{array}{l}-0.451 * \\
{[0.264]}\end{array}$ & $\begin{array}{c}-0.521 * * \\
{[0.213]}\end{array}$ \\
\hline Quintile $=3$ & $\begin{array}{c}-0.141^{*} \\
{[0.085]}\end{array}$ & $\begin{array}{c}-0.053 \\
{[0.048]}\end{array}$ & $\begin{array}{c}-0.161^{*} \\
{[0.083]}\end{array}$ & $\begin{array}{c}-0.187 * \\
{[0.108]}\end{array}$ & $\begin{array}{c}-0.135 \\
{[0.089]}\end{array}$ & $\begin{array}{c}-0.146 \\
{[0.116]}\end{array}$ \\
\hline Quintile $=4$ & $\begin{array}{c}-0.177 * * \\
{[0.076]}\end{array}$ & $\begin{array}{c}-0.032 \\
{[0.082]}\end{array}$ & $\begin{array}{c}-0.109 * * \\
{[0.044]}\end{array}$ & $\begin{array}{c}-0.159 \\
{[0.128]}\end{array}$ & $\begin{array}{c}-0.009 \\
{[0.076]}\end{array}$ & $\begin{array}{c}-0.169 \\
{[0.147]}\end{array}$ \\
\hline Quintile $=5$ & $\begin{array}{c}-0.018 \\
{[0.063]}\end{array}$ & $\begin{array}{c}-0.001 \\
{[0.020]}\end{array}$ & $\begin{array}{c}-0.045 \\
{[0.054]}\end{array}$ & $\begin{array}{c}0.016 \\
{[0.071]}\end{array}$ & $\begin{array}{c}0.032 \\
{[0.037]}\end{array}$ & $\begin{array}{c}0.023 \\
{[0.085]}\end{array}$ \\
\hline \multicolumn{7}{|l|}{ D) Time of Arrival in Turkey } \\
\hline First arrival $<1$ year & $\begin{array}{c}0.124 \\
{[0.171]}\end{array}$ & $\begin{array}{c}0.003 \\
{[0.029]}\end{array}$ & $\begin{array}{c}0.194 \\
{[0.165]}\end{array}$ & $\begin{array}{c}0.063 \\
{[0.406]}\end{array}$ & $\begin{array}{c}0.065 \\
{[0.234]}\end{array}$ & $\begin{array}{c}0.367 \\
{[0.374]}\end{array}$ \\
\hline First arrival $=1$ to 3 years & $\begin{array}{c}-0.155^{* * *} \\
{[0.039]}\end{array}$ & $\begin{array}{c}0.039 * \\
{[0.024]}\end{array}$ & $\begin{array}{c}-0.067^{* *} \\
{[0.029]}\end{array}$ & $\begin{array}{c}-0.225 * * * \\
{[0.076]}\end{array}$ & $\begin{array}{c}-0.030 \\
{[0.071]}\end{array}$ & $\begin{array}{c}-0.157 * * \\
{[0.067]}\end{array}$ \\
\hline First arrival $>3$ years & $\begin{array}{c}-0.166^{* * *} \\
{[0.029]}\end{array}$ & $\begin{array}{c}-0.061 * * * \\
{[0.015]}\end{array}$ & $\begin{array}{c}-0.178^{* * *} \\
{[0.024]}\end{array}$ & $\begin{array}{c}-0.202 * * * \\
{[0.063]}\end{array}$ & $\begin{array}{c}-0.209^{* * *} \\
{[0.072]}\end{array}$ & $\begin{array}{c}-0.301 * * * \\
{[0.043]}\end{array}$ \\
\hline \multicolumn{7}{|l|}{ E) Nationality } \\
\hline Syrian & $\begin{array}{c}-0.173 * * * \\
{[0.037]}\end{array}$ & $\begin{array}{c}-0.045^{* * *} \\
{[0.015]}\end{array}$ & $\begin{array}{c}-0.148 * * * \\
{[0.027]}\end{array}$ & $\begin{array}{c}-0.221 * * * \\
{[0.049]}\end{array}$ & $\begin{array}{c}-0.204^{* * *} * \\
{[0.055]}\end{array}$ & $\begin{array}{c}-0.277 * * * \\
{[0.054]}\end{array}$ \\
\hline Other Nationality & $\begin{array}{c}-0.078 * * * \\
{[0.026]}\end{array}$ & $\begin{array}{c}0.013 \\
{[0.011]} \\
\end{array}$ & $\begin{array}{c}-0.051^{*} \\
{[0.028]}\end{array}$ & $\begin{array}{c}-0.081 \\
{[0.061]} \\
\end{array}$ & $\begin{array}{c}0.016 \\
{[0.062]} \\
\end{array}$ & $\begin{array}{c}-0.045 \\
{[0.076]} \\
\end{array}$ \\
\hline \multicolumn{7}{|l|}{ F) Refugee Intensity } \\
\hline High & $\begin{array}{c}-0.176^{* * *} \\
{[0.048]}\end{array}$ & $\begin{array}{c}-0.023 \\
{[0.050]}\end{array}$ & $\begin{array}{c}-0.121 * * \\
{[0.050]}\end{array}$ & $\begin{array}{c}-0.195 * * * \\
{[0.053]}\end{array}$ & $\begin{array}{c}-0.147 * * \\
{[0.072]}\end{array}$ & $\begin{array}{c}-0.259 * * * \\
{[0.068]}\end{array}$ \\
\hline Low & $\begin{array}{c}-0.129 * * * \\
{[0.031]}\end{array}$ & $\begin{array}{l}-0.031^{*} \\
{[0.019]}\end{array}$ & $\begin{array}{c}-0.114^{* * *} \\
{[0.018]}\end{array}$ & $\begin{array}{c}-0.164 * * * \\
{[0.050]}\end{array}$ & $\begin{array}{c}-0.135^{* * *} \\
{[0.043]}\end{array}$ & $\begin{array}{c}-0.203^{* * *} \\
{[0.052]}\end{array}$ \\
\hline
\end{tabular}

Notes: The data come from the rounds three and four of the Comprehensive Vulnerability Monitoring Exercise of Turkey. The sample is restricted to households for which the dependency ratio is between zero and three. Each cell comes from a separate regression. The cells for the share of children working in panel (A) are missing because this information is not available by age groups. The set of control variables is the same as those in the previous tables. High refugee-intensity area is defined as the five NUTS-2 regions with the highest refugee percentage (Hatay, Gaziantep, Sanliurfa, Adana, and Mardin regions). Clustering is done at the level of dependency ratio. Statistically significant: *** 1 percent level; ** 5 percent level, * 10 percent level. 


\section{APPENDIX: FOR ONLINE PUBLICATION}

\section{APPENDIX A - Supplementary Descriptive Statistics}

Figure A1. Number of Syrian Refugees under Temporary Protection in Turkey, 2011-2020

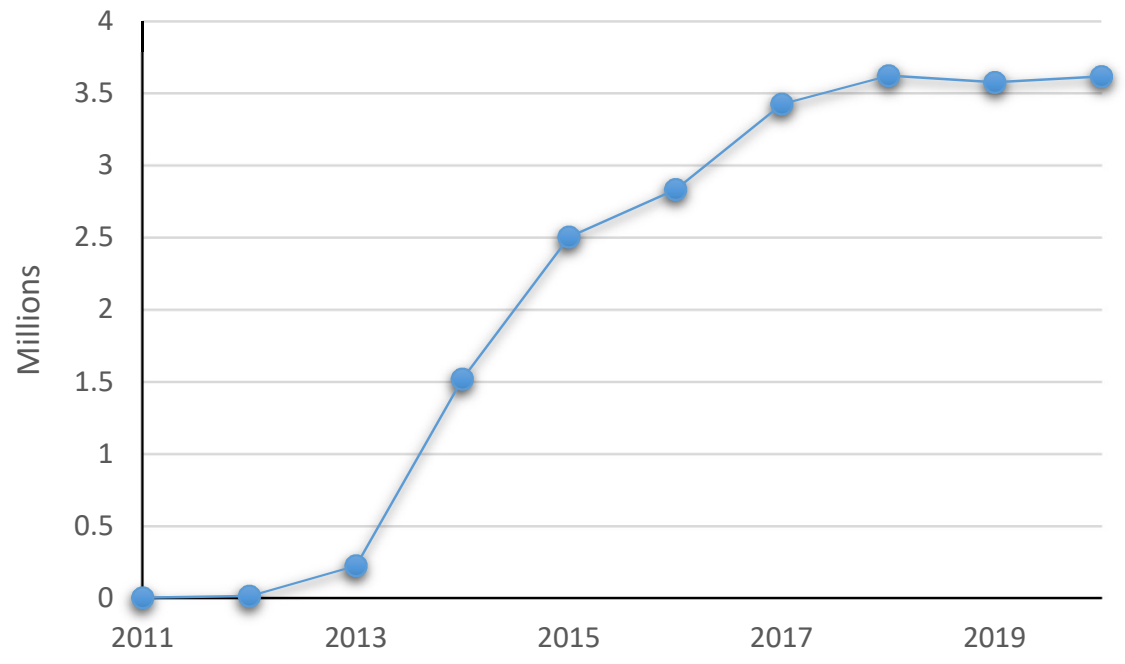

Source: DGMM (2020) 
Table A1. Schooling rates of Syrian refugee children (as a \% of the age group), 2014-2020

\begin{tabular}{l|ccccccc} 
Education level & $\mathbf{2 0 1 4}$ & $\mathbf{2 0 1 5}$ & $\mathbf{2 0 1 6}$ & $\mathbf{2 0 1 7}$ & $\mathbf{2 0 1 8}$ & $\mathbf{2 0 1 9}$ & $\mathbf{2 0 2 0}$ \\
\hline Pre-school & n.a & 25 & 30 & 36 & 33 & 27 & 24 \\
Primary school & n.a & 80 & 101 & 98 & 97 & 89 & 80 \\
Secondary school & n.a & 40 & 46 & 51 & 58 & 71 & 79 \\
High school & n.a & 17 & 21 & 22 & 26 & 33 & 40 \\
\hline Overall & 30 & 37 & 59 & 63 & 61 & 63 & 64 \\
\hline \hline
\end{tabular}

Source: MoNE Directorate of Lifetime Learning (2017, 2018, 2019, 2020a)

Note: All data points refer to the Fall semester of the corresponding year. 
Table A2: Descriptive Statistics for Control Variables

\begin{tabular}{|c|c|c|c|}
\hline Eligibility Criteria \& Registration Status & & usehold Head Characteristics & \\
\hline Eligible for ESSN via a criterion other than Dependency Ratio & 0.484 & Nationality & \\
\hline Single Women & 0.005 & Afghan & 0.076 \\
\hline Single parents with at least one child & 0.040 & Iraqi & 0.194 \\
\hline Elderly with no other adults in the household & 0.012 & Syrian & 0.719 \\
\hline At least four children & 0.372 & Other & 0.012 \\
\hline At least one disabled person with a report & 0.126 & Time Since Arrival in Turkey & \\
\hline Dependency Ratio $>=1.5$ & 0.493 & Less than 6 months & 0.032 \\
\hline Number of members registered to DGMM & 5.561 & 6 months - 1 year & 0.069 \\
\hline Household registered to Civil Registry & 0.904 & 1 year -3 years & 0.304 \\
\hline Household Composition & & More than 3 years & 0.581 \\
\hline Household size & 5.845 & Before the conflict started & 0.014 \\
\hline Number of children aged 6-17 & 1.887 & Region & \\
\hline Number of children below age 6 & 1.246 & İstanbul Region & 0.028 \\
\hline Household Head Characteristics & & West Marmara Region & 0.047 \\
\hline Female & 0.177 & Aegean Region & 0.121 \\
\hline Education & & East Marmara Region & 0.075 \\
\hline Missing & 0.007 & West Anatolia Region & 0.140 \\
\hline Illiterate & 0.209 & Mediterranean Region & 0.093 \\
\hline Literate & 0.125 & Central Anatolia Region & 0.149 \\
\hline Primary School & 0.306 & West Black Sea Region & 0.103 \\
\hline Middle School or High School & 0.286 & East Black Sea Region & 0.009 \\
\hline University & 0.067 & Northeast Anatolia Region & 0.029 \\
\hline Occupation before Arrival & & Central East Anatolia Region & 0.047 \\
\hline Management/highly skilled & 0.062 & Southeast Anatolia Region & 0.159 \\
\hline Skilled worker & 0.101 & & \\
\hline Unskilled worker & 0.744 & & \\
\hline Retirement salary & 0.006 & & \\
\hline Other & 0.062 & & \\
\hline Not employed & 0.025 & & \\
\hline
\end{tabular}

Notes: The data come from the rounds three and four of the Comprehensive Vulnerability Monitoring Exercise (CVME) of Turkey. The sample size is $2,681$. Meeting the 6 eligibility criterion is subject to household demographic composition as written in the table, registration with Directorate General for Migration Management (DGMM), and Civil Registry. All variables are binary except for number of household members registered to DGMM, the household size, number of children aged 6-17, and the number of children below age 6. The Standard Deviation (SD), Minimum (Min), and Maximum of these variables are as follows: Number of members registered to DGMM: SD: 2.603, Min: 1, Max:15; Household size: SD: 2.461, Min: 1, Max:15; Number of children aged 6-17: SD: 1.720, Min:0, Max: 8; Number of children below age 6: SD: 1.152, Min:0, Max:8. 
Table A3: Mean Values of Main Outcomes by Nationality and Time since Arrival

\begin{tabular}{|c|c|c|c|c|c|}
\hline & \multicolumn{2}{|c|}{ Nationality } & \multicolumn{3}{|c|}{ Time since Arrival } \\
\hline & Syrian & Other & $<1$ year & $1-3$ years & $>3$ years \\
\hline Beneficiary household & 0.523 & 0.499 & 0.515 & 0.511 & 0.519 \\
\hline Number of boys under 18 who worked in the last 30 days & 0.186 & 0.076 & 0.133 & 0.154 & 0.159 \\
\hline Number of girls under 18 who worked in the last 30 days & 0.048 & 0.012 & 0.015 & 0.033 & 0.044 \\
\hline Share of boys under 18 who worked in the last 30 days & 0.101 & 0.043 & 0.067 & 0.078 & 0.090 \\
\hline Share of girls under 18 who worked in the last 30 days & 0.023 & 0.005 & 0.005 & 0.014 & 0.022 \\
\hline Number of boys aged 6-17 who did not attend school last semester & 0.345 & 0.300 & 0.563 & 0.321 & 0.299 \\
\hline Number of girls aged 6-17 who did not attend school last semester & 0.322 & 0.300 & 0.507 & 0.297 & 0.293 \\
\hline Share of boys aged 6-17 who did not attend school last semester & 0.193 & 0.174 & 0.294 & 0.172 & 0.177 \\
\hline Share of girls aged 6-17 who did not attend school last semester & 0.167 & 0.163 & 0.231 & 0.158 & 0.159 \\
\hline \multicolumn{6}{|l|}{ Income, Poverty, Assets and Housing } \\
\hline Main Income Source is WFP/TRC Assistance (last 30 days) & 0.369 & 0.456 & 0.470 & 0.371 & 0.391 \\
\hline Secondary or Third Income Source is WFP/TRC Assistance (last 30 days) & 0.205 & 0.216 & 0.174 & 0.223 & 0.206 \\
\hline Poverty Gap - 5.5 USD PPP Line & 0.154 & 0.142 & 0.235 & 0.143 & 0.140 \\
\hline Squared Poverty Gap - Poverty Gap - 5.5 USD PPP Line & 0.060 & 0.058 & 0.107 & 0.053 & 0.054 \\
\hline Poverty Gap - Relative Poverty Line (1st Quintile of Consumption) & 0.030 & 0.035 & 0.071 & 0.026 & 0.028 \\
\hline Squared Poverty Gap - Relative Poverty Line (1st Quintile of Consumption) & 0.010 & 0.012 & 0.027 & 0.008 & 0.009 \\
\hline Housing Index (Sum of Positive Housing Characteristics) & 7.822 & 7.585 & 7.435 & 7.750 & 7.812 \\
\hline Asset Index (Total Number of Household Assets) & 8.591 & 8.819 & 7.370 & 8.580 & 8.912 \\
\hline \multicolumn{6}{|l|}{ Consumption, Coping Mechanism and Child Health } \\
\hline Annual Consumption Spending per Person (Top 1\% Censored, in thousands) & 4.874 & 4.953 & 4.128 & 4.878 & 5.036 \\
\hline Annual Food Spending per Person (Top 1\% Censored, in thousands) & 2.444 & 2.140 & 1.903 & 2.306 & 2.463 \\
\hline Annual Non-Food Spending per Person (Top 1\% Censored, in thousands) & 2.402 & 2.786 & 2.172 & 2.552 & 2.545 \\
\hline Food Consumption Score (FCS) & 78.173 & 79.068 & 70.813 & 78.557 & 79.645 \\
\hline Reduced Coping Strategy Index (0-56, the higher the worse) & 12.177 & 16.353 & 20.707 & 14.294 & 11.622 \\
\hline Livelihood Coping Strategies (0-13, the higher the worse) (Last 30 Days) & 1.664 & 1.610 & 1.893 & 1.695 & 1.584 \\
\hline Number of Sick Children (Last 30 Days) & 0.609 & 0.788 & 0.889 & 0.748 & 0.576 \\
\hline Number of Sick Children for Whom Treatment Sought (Last 30 Days) & 0.565 & 0.669 & 0.733 & 0.673 & 0.531 \\
\hline \multicolumn{6}{|l|}{ Reasons for Children Not Attending School } \\
\hline Children need to work & 0.127 & 0.044 & 0.059 & 0.099 & 0.113 \\
\hline Children need to stay home and assist family & 0.032 & 0.007 & 0.004 & 0.026 & 0.028 \\
\hline Family cannot afford to pay school expenses & 0.040 & 0.042 & 0.048 & 0.032 & 0.044 \\
\hline Children sick/unwell & 0.011 & 0.009 & 0.007 & 0.006 & 0.014 \\
\hline
\end{tabular}

Notes: The data come from the rounds three and four of the Comprehensive Vulnerability Monitoring Exercise (CVME) of Turkey. The sample size is 1,301 in wave 3 and 1,380 in wave 4 . 


\section{APPENDIX B - Checks of RDD Assumptions}

Figure B1: Histogram of the Running Variable

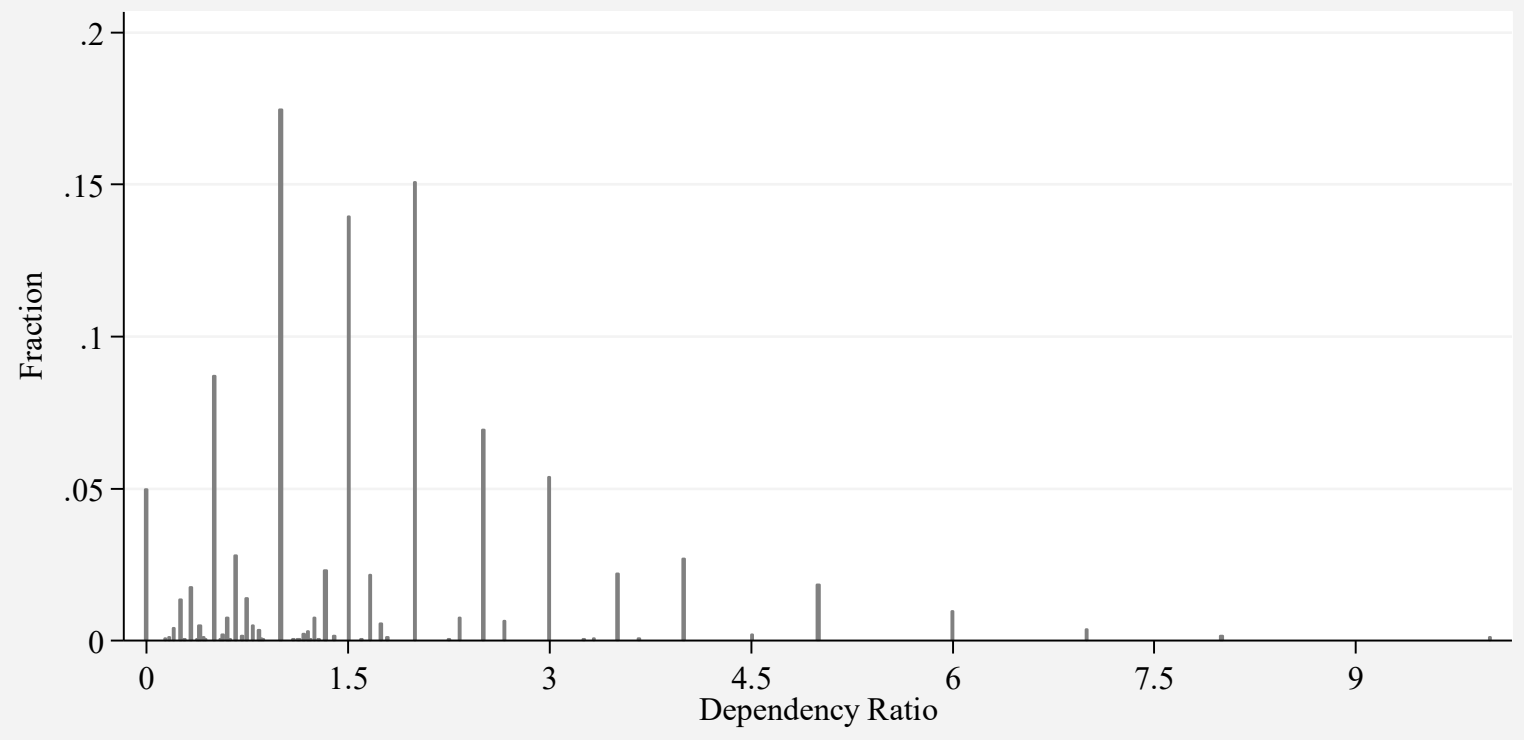


Figure B2: Estimated Density of the Running Variable and Cattaneo-Jansson-Ma Tests

1) Estimated Density of the Running Variable at Alternative Cutoffs

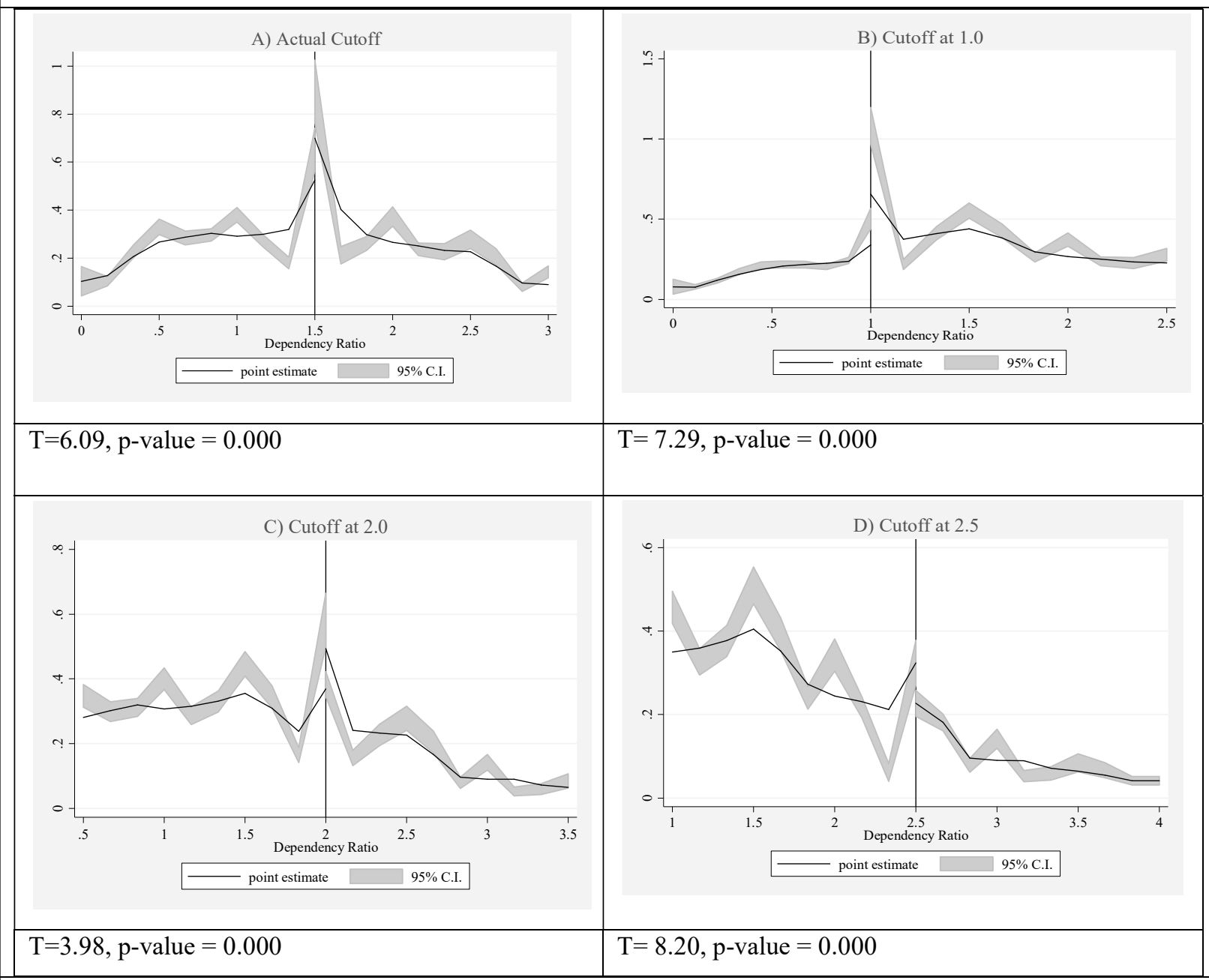

2) Estimated Density of the Running Variable When "Dependency Ratio=1.5" is Excluded

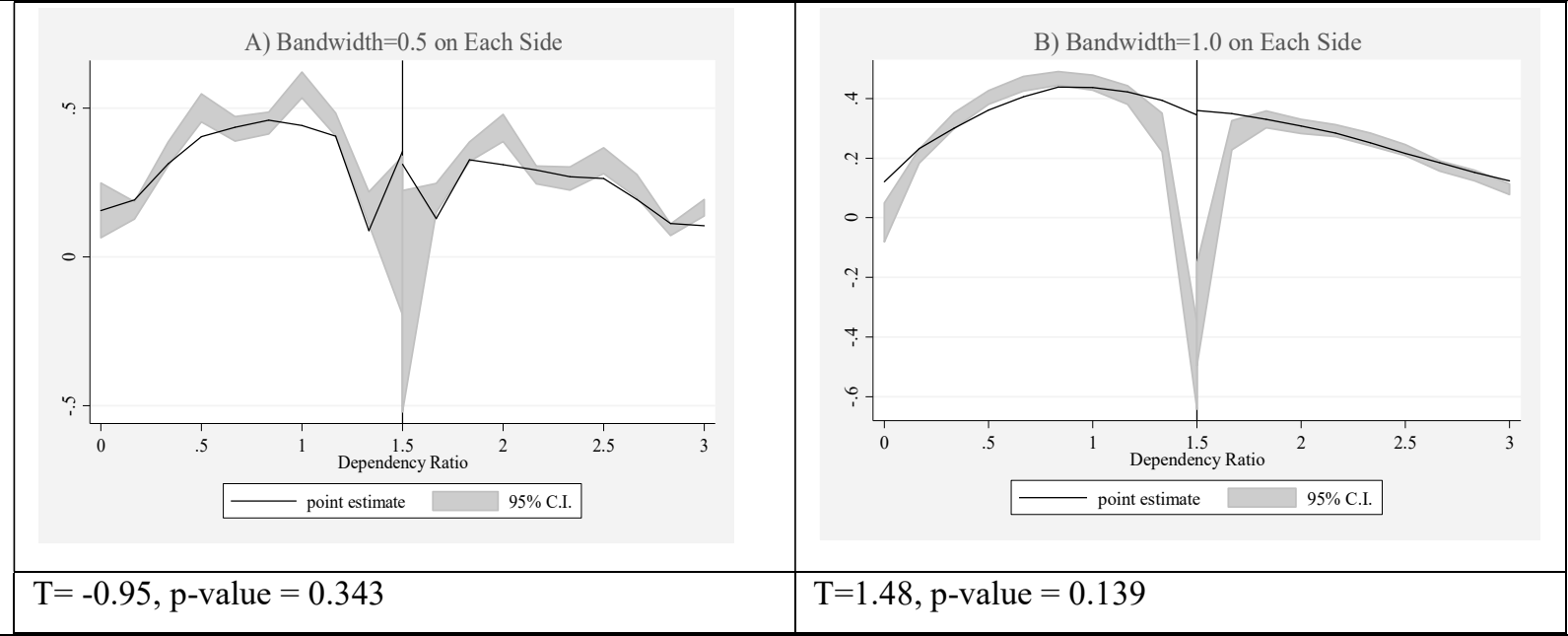

Notes: Bandwidths on each side of the cutoff are set to 0.5 in panel 1 and panel $2 \mathrm{~A}$ and to 1.0 in panel 2B. 
Table B1: Check of Discontinuity at the Cutoff for Other Covariates

\begin{tabular}{|c|c|c|c|c|c|}
\hline (1) & $(2)$ & (3) & (4) & (5) & $(6)$ \\
\hline & RD Effect & p-value & & RD Effect & p-value \\
\hline Eligibile for ESSN via a criterion other than DR & -0.196 & 0.412 & Household Head Characteristics & & \\
\hline Household Composition & & & Time Since Arrival in Turkey & & \\
\hline Household Size & -1.477 & 0.241 & Less than 6 months & 0.006 & 0.369 \\
\hline Number of children aged 6 to 17 & -0.458 & 0.382 & 6 months - 1 year & 0.023 & 0.059 \\
\hline Number of children below age 6 & -0.220 & 0.256 & 1 year -3 years & -0.014 & 0.626 \\
\hline Household Head Characteristics & & & More than 3 years & -0.011 & 0.695 \\
\hline Female & -0.039 & 0.167 & Before the conflict started & -0.005 & 0.396 \\
\hline Education & & & Region & & \\
\hline Missing & 0.001 & 0.884 & İstanbul Region & 0.005 & 0.417 \\
\hline Illiterate & 0.018 & 0.228 & West Marmara Region & -0.008 & 0.740 \\
\hline Literate & -0.012 & 0.396 & Aegean Region & 0.016 & 0.298 \\
\hline Primary School & 0.002 & 0.961 & East Marmara Region & -0.023 & 0.391 \\
\hline Middle School or High School & -0.001 & 0.979 & West Anatolia Region & -0.025 & 0.514 \\
\hline University & -0.008 & 0.727 & Mediterranean Region & -0.053 & 0.080 \\
\hline Occupation before Arrival & & & Central Anatolia Region & 0.027 & 0.155 \\
\hline Management/highly skilled & 0.011 & 0.359 & West Black Sea Region & -0.011 & 0.643 \\
\hline Skilled worker & 0.027 & 0.154 & East Black Sea Region & -0.005 & 0.304 \\
\hline Unskilled worker & -0.039 & 0.147 & Northeast Anatolia Region & 0.007 & 0.590 \\
\hline Retirement salary & 0.002 & 0.761 & Central East Anatolia Region & 0.015 & 0.269 \\
\hline Other & -0.002 & 0.939 & Southeast Anatolia Region & 0.057 & 0.053 \\
\hline Not employed & -0.001 & 0.959 & & & \\
\hline \multicolumn{6}{|l|}{ Nationality } \\
\hline Afghan & -0.018 & 0.074 & & & \\
\hline Iraqi & -0.009 & 0.732 & & & \\
\hline Syrian & 0.032 & 0.140 & & & \\
\hline Other & -0.005 & 0.546 & & & \\
\hline
\end{tabular}

Notes: DR stands for dependency ratio. The data come from the rounds three and four of the Comprehensive Vulnerability Monitoring Exercise (CVME) of Turkey. A bandwidth of 1.5 is taken on either side of the cutoff; in other words, the dependency ratio ranges between 0 and 3 . The sample size is 2,448 . The dependent variable is given in column headings (1) and (4). All dependent variables are binary except for the number of children below age six and the number of prime adults. All regressions include a control for the policy dummy and split linear polynomials around the cutoff in the running variable (dependency ratio). Clustering is done at the level of dependency ratio. Statistically significant: *** 1 percent level; ** 5 percent level, * 10 percent level. 
Table B2: Continuity-based Analysis for Alternative Cutoffs

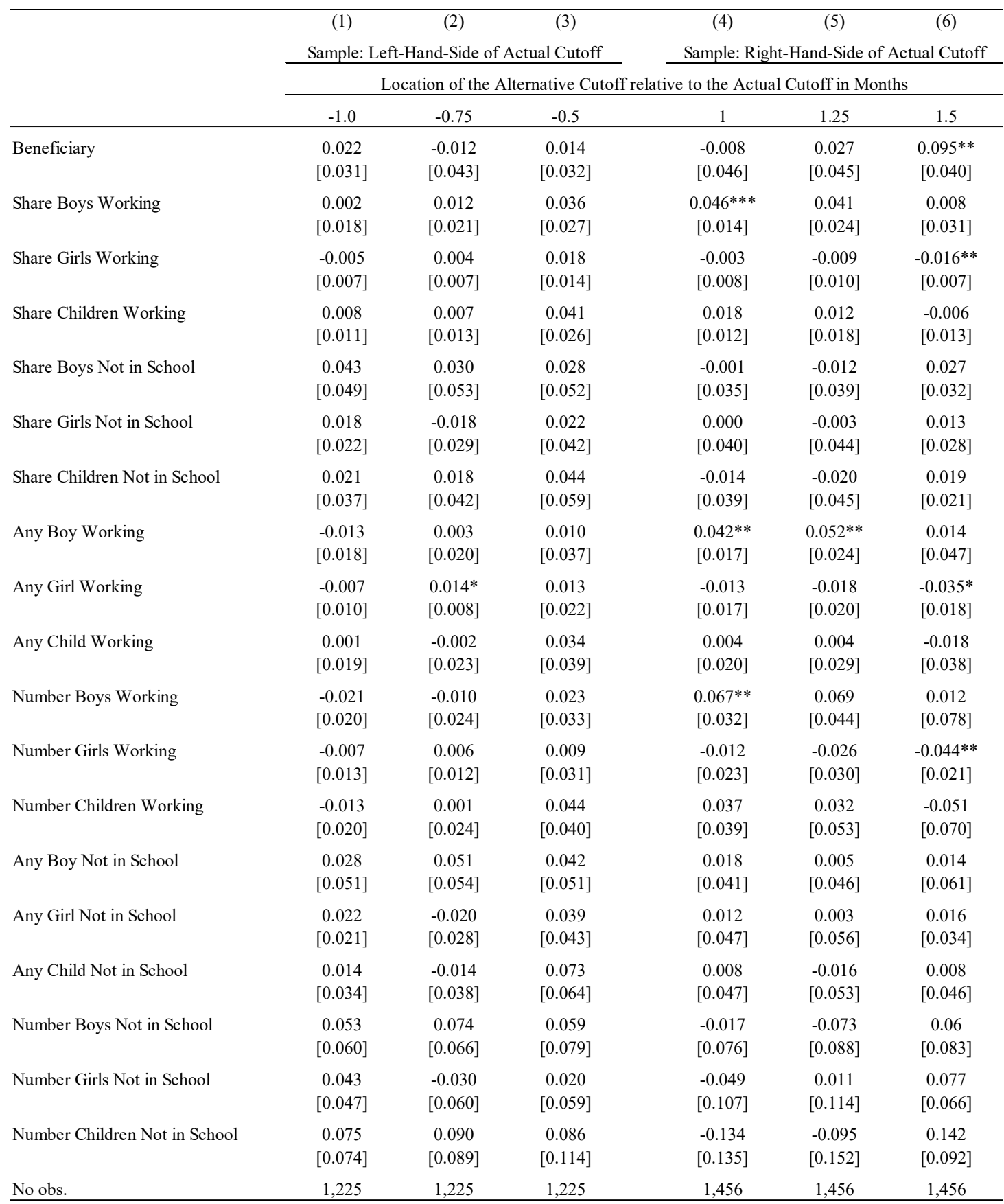

Notes: The data come from the rounds three and four of the Comprehensive Vulnerability Monitoring Exercise (CVME) of Turkey. The sample is restricted to the left of the actual cutoff in columns (1) to (3) and to the right of the actual cutoff in columns (4) to (6). Hence, the cutoff is at $\mathrm{DR}=0.5 \mathrm{in}$ column (1), DR=0.75 in column (2), $\mathrm{DR}=1.0$ in column (3), $\mathrm{DR}=2.5$ in column (4), $\mathrm{DR}=2.75$ in column (5), and $\mathrm{DR}=3.0$ in column (6) -- where DR stands for dependency ratio. These cutoffs are chosen so that a sufficient number of points remains on either side of the cutoff. Each cell comes from a separate regression. All regressions include a control for the policy dummy, split linear polynomials around the cutoff in the running variable (dependency ratio), and several control variables. These controls include a dummy variable for ESSN program eligibility via any of the five other eligibility criteria other than that on the dependency ratio, the number total household members, the number of children below age six, the number of children aged 6-17, dummies for household head's sex, education (illiterate, literate, primary/intermediate, secondary, technical, university), occupation before arrival (management/highly skilled, skilled worker, unskilled worker, retired, other), nationality (Afghan, Iraqi, Syrian, other), time of arrival (less than 6 months, 6 months-1 year, 1 year - 3 years, more than 3 years, before the conflict started), and 12 NUTS-1 level regions. In addition, dummy variables for different values of number of boys are used for dependent variables for boys, dummy variables for different values of number of girls are used for dependent variables for girls, and dummy variables for different values of number of children are used for dependent variables for all children. Clustering is done at the level of dependency ratio. Statistically significant: *** 1 percent level; ** 5 percent level, $* 10$ percent level. 


\section{APPENDIX C - Supplementary Results}

Figure C1: The Effect of Dependency-Ratio Criterion on Children's School and Employment Outcomes as Dummy Variables

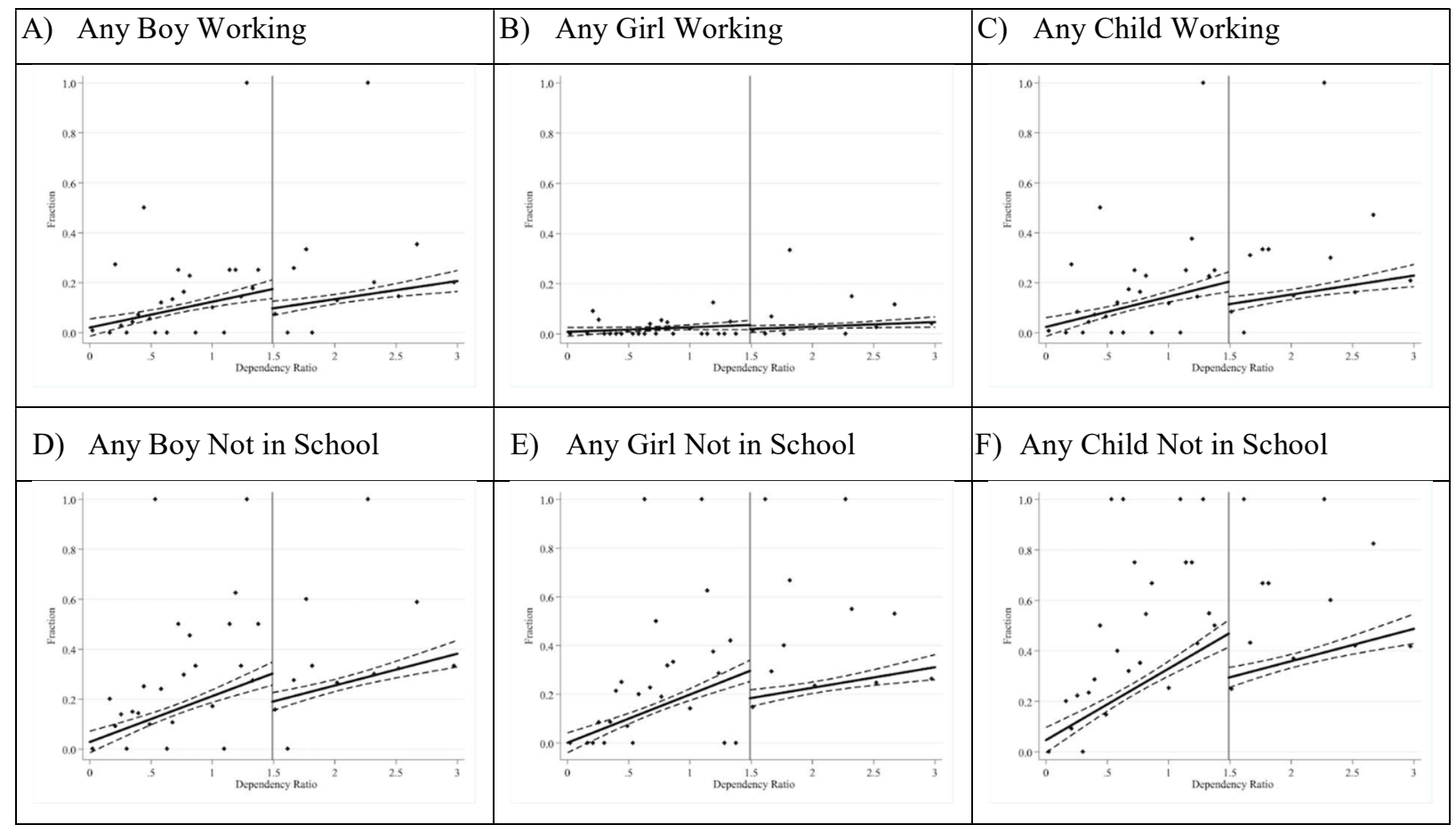


Table C1: The Effect of Dependency-Ratio Criterion on Any Children Working and Any Children not in School by Gender

\begin{tabular}{|c|c|c|c|c|c|c|c|c|c|}
\hline$(1)$ & $(2)$ & (3) & (4) & $(5)$ & (6) & $(7)$ & (8) & (9) & (10) \\
\hline & Beneficiary & $\begin{array}{c}\text { Any boy } \\
\text { works }\end{array}$ & $\begin{array}{c}\text { Any girls } \\
\text { works }\end{array}$ & $\begin{array}{c}\text { Any child } \\
\text { works }\end{array}$ & $\begin{array}{c}\text { Any Boy not } \\
\text { in school }\end{array}$ & $\begin{array}{c}\text { Any Girl not } \\
\text { in school }\end{array}$ & $\begin{array}{c}\text { Any Child } \\
\text { not in school }\end{array}$ & No obs. & $\begin{array}{c}\text { No. } \\
\text { cluster }\end{array}$ \\
\hline \multicolumn{10}{|l|}{ A) Baseline } \\
\hline Full Data & $\begin{array}{c}0.307 * * * \\
{[0.084]}\end{array}$ & $\begin{array}{c}-0.058^{* * *} \\
{[0.013]}\end{array}$ & $\begin{array}{c}-0.015^{* *} \\
{[0.007]}\end{array}$ & $\begin{array}{c}-0.071^{* * *} \\
{[0.016]}\end{array}$ & $\begin{array}{c}-0.072 * * * \\
{[0.019]}\end{array}$ & $\begin{array}{c}-0.068 * * * \\
{[0.017]}\end{array}$ & $\begin{array}{c}-0.110^{* * *} \\
{[0.018]}\end{array}$ & 2,681 & 56 \\
\hline $0<=\mathrm{DR}<=4.5$ & $\begin{array}{c}0.334 * * * \\
{[0.086]}\end{array}$ & $\begin{array}{c}-0.050^{* * *} \\
{[0.014]}\end{array}$ & $\begin{array}{l}-0.011^{*} \\
{[0.006]}\end{array}$ & $\begin{array}{c}-0.057^{* * *} \\
{[0.018]}\end{array}$ & $\begin{array}{c}-0.075^{* * *} \\
{[0.018]}\end{array}$ & $\begin{array}{c}-0.071 * * * \\
{[0.016]}\end{array}$ & $\begin{array}{c}-0.107 * * * \\
{[0.019]}\end{array}$ & 2,589 & 51 \\
\hline $0<=\mathrm{DR}<=3.5$ & $\begin{array}{c}0.356^{* * *} \\
{[0.083]}\end{array}$ & $\begin{array}{c}-0.055^{* * *} \\
{[0.013]}\end{array}$ & $\begin{array}{c}-0.009 \\
{[0.006]}\end{array}$ & $\begin{array}{c}-0.057^{* * *} \\
{[0.019]}\end{array}$ & $\begin{array}{c}-0.077^{* * *} \\
{[0.019]}\end{array}$ & $\begin{array}{c}-0.069^{* * *} \\
{[0.017]}\end{array}$ & $\begin{array}{c}-0.104 * * * \\
{[0.019]}\end{array}$ & 2,510 & 48 \\
\hline $0<=\mathrm{DR}<=3.0$ & $\begin{array}{c}0.377 * * * \\
{[0.077]}\end{array}$ & $\begin{array}{c}-0.051^{* * *} \\
{[0.015]}\end{array}$ & $\begin{array}{c}-0.010 \\
{[0.006]}\end{array}$ & $\begin{array}{c}-0.056^{* * *} \\
{[0.020]}\end{array}$ & $\begin{array}{c}-0.067^{* * *} \\
{[0.020]}\end{array}$ & $\begin{array}{c}-0.063^{* * *} \\
{[0.018]}\end{array}$ & $\begin{array}{c}-0.097 * * * \\
{[0.021]}\end{array}$ & 2,448 & 45 \\
\hline $0.5<=\mathrm{DR}<=2.5$ & $\begin{array}{c}0.350 * * * \\
{[0.084]}\end{array}$ & $\begin{array}{c}-0.032 \\
{[0.023]}\end{array}$ & $\begin{array}{c}-0.005 \\
{[0.006]}\end{array}$ & $\begin{array}{l}-0.038 \\
{[0.025]}\end{array}$ & $\begin{array}{c}-0.054^{* *} \\
{[0.025]} \\
\end{array}$ & $\begin{array}{c}-0.053^{* *} \\
{[0.024]}\end{array}$ & $\begin{array}{c}-0.070^{* * *} \\
{[0.022]} \\
\end{array}$ & 2,036 & 32 \\
\hline \multicolumn{10}{|l|}{ B) Full Controls } \\
\hline Full Data & $\begin{array}{c}0.318^{* * *} \\
{[0.073]}\end{array}$ & $\begin{array}{c}-0.054 * * * \\
{[0.014]}\end{array}$ & $\begin{array}{c}-0.010 \\
{[0.008]}\end{array}$ & $\begin{array}{c}-0.066^{* * *} \\
{[0.016]}\end{array}$ & $\begin{array}{c}-0.067 * * * \\
{[0.023]}\end{array}$ & $\begin{array}{c}-0.060 * * * \\
{[0.020]}\end{array}$ & $\begin{array}{c}-0.102 * * * \\
{[0.017]}\end{array}$ & 2,681 & 56 \\
\hline $0<=\mathrm{DR}<=4.5$ & $\begin{array}{c}0.346^{* * *} \\
{[0.073]}\end{array}$ & $\begin{array}{c}-0.048^{* * *} \\
{[0.014]}\end{array}$ & $\begin{array}{c}-0.008 \\
{[0.007]}\end{array}$ & $\begin{array}{c}-0.057^{* * *} \\
{[0.017]}\end{array}$ & $\begin{array}{c}-0.069 * * * \\
{[0.022]}\end{array}$ & $\begin{array}{c}-0.063 * * * \\
{[0.020]}\end{array}$ & $\begin{array}{c}-0.102 * * * \\
{[0.017]}\end{array}$ & 2,589 & 51 \\
\hline $0<=\mathrm{DR}<=3.5$ & $\begin{array}{c}0.376^{* * *} \\
{[0.066]}\end{array}$ & $\begin{array}{c}-0.053^{* * *} \\
{[0.014]}\end{array}$ & $\begin{array}{c}-0.006 \\
{[0.008]}\end{array}$ & $\begin{array}{c}-0.060 * * * \\
{[0.017]}\end{array}$ & $\begin{array}{c}-0.074 * * * \\
{[0.021]}\end{array}$ & $\begin{array}{c}-0.064 * * * \\
{[0.019]}\end{array}$ & $\begin{array}{c}-0.105^{* * *} \\
{[0.016]}\end{array}$ & 2,510 & 48 \\
\hline $0<=\mathrm{DR}<=3.0$ & $\begin{array}{c}0.389 * * * \\
{[0.064]}\end{array}$ & $\begin{array}{c}-0.048^{* * *} \\
{[0.014]}\end{array}$ & $\begin{array}{c}-0.007 \\
{[0.008]}\end{array}$ & $\begin{array}{c}-0.058^{* * *} \\
{[0.018]}\end{array}$ & $\begin{array}{c}-0.066^{* * *} \\
{[0.021]}\end{array}$ & $\begin{array}{c}-0.060^{* * *} \\
{[0.020]}\end{array}$ & $\begin{array}{c}-0.098^{* * *} \\
{[0.017]}\end{array}$ & 2,448 & 45 \\
\hline $0.5<=\mathrm{DR}<=2.5$ & $\begin{array}{c}0.371 * * * \\
{[0.074]}\end{array}$ & $\begin{array}{c}-0.026 \\
{[0.020]}\end{array}$ & $\begin{array}{c}-0.002 \\
{[0.010]}\end{array}$ & $\begin{array}{l}-0.041 \\
{[0.026]}\end{array}$ & $\begin{array}{l}-0.052^{*} \\
{[0.030]}\end{array}$ & $\begin{array}{l}-0.049 * \\
{[0.028]}\end{array}$ & $\begin{array}{c}-0.073 * * * \\
{[0.024]}\end{array}$ & 2,036 & 32 \\
\hline
\end{tabular}

Notes: "DR" stands for dependency ratio. The data come from the rounds three and four of the Comprehensive Vulnerability Monitoring Exercise (CVME) of Turkey. The sample is restricted to various bandwidths around the cutoff (dependency ratio=1.5) as given in column (1). The dependent variable is given in column headings (2) to (8). Each cell comes from a separate regression. All regressions include a control for the policy dummy and split linear polynomials around the cutoff in the running variable (dependency ratio). The baseline specification in panel (A), in addition, include a dummy variable for ESSN program eligibility via any of the five other eligibility criteria (single women, single parents with at least one child, elderly with no other adult in the household, families with at least four children, families with at least one disabled person with a report) in column (2), and dummy variables for different values of number of boys in columns (3) and (8), for different values of number of girls in columns (4) and (7) and for different values of number of children in columns (5) and (8). The full specification, in panel (B) also includes household characteristics including the number total household members, the number of children below age six, the number of children aged 6-17, dummies for household head's sex, education (illiterate, literate, primary/intermediate, secondary, technical, university), occupation before arrival (management/highly skilled, skilled worker, unskilled worker, retired, other), nationality (Afghan, Iraqi, Syrian, other), time of arrival (less than 6 months, 6 months- 1 year, 1 year - 3 years, more than 3 years, before the conflict started), and 12 NUTS-1 level regions in all columns. Panel (B) also adds the dummy variable for eligibility status via any other channel to columns (3) to (8). Clustering is done at the level of dependency ratio. Statistically significant: *** 1 percent level; ** 5 percent level, * 10 percent level. 
Table C2: The Effect of Dependency-Ratio Criterion on Number of Children Working and Number of Children not in School - Local Polynomial Approach with Baseline Variables and a Triangular Kernel

\begin{tabular}{|c|c|c|c|c|c|c|c|}
\hline$(1)$ & (2) & (3) & (4) & $(5)$ & (6) & (7) & $(8)$ \\
\hline & Beneficiary & $\begin{array}{l}\text { Number } \\
\text { boys } \\
\text { working }\end{array}$ & $\begin{array}{l}\text { Number } \\
\text { girls } \\
\text { working }\end{array}$ & $\begin{array}{l}\text { Number } \\
\text { children } \\
\text { working }\end{array}$ & $\begin{array}{c}\text { Number } \\
\text { boys not in } \\
\text { school }\end{array}$ & $\begin{array}{c}\text { Number } \\
\text { girls not in } \\
\text { school }\end{array}$ & $\begin{array}{c}\text { Number } \\
\text { children not } \\
\text { in school }\end{array}$ \\
\hline \multicolumn{8}{|l|}{ A) IK Bandwidths } \\
\hline Bandwidth $=\mathrm{b}$ & $\begin{array}{c}0.370 * * * \\
(0.050)\end{array}$ & $\begin{array}{c}-0.096^{* * *} \\
(0.021)\end{array}$ & $\begin{array}{l}-0.010 \\
(0.013)\end{array}$ & $\begin{array}{c}-0.074 * * * \\
(0.025)\end{array}$ & $\begin{array}{c}-0.131 * * \\
(0.063)\end{array}$ & $\begin{array}{c}-0.110 * * \\
(0.049)\end{array}$ & $\begin{array}{c}-0.227 * * * \\
(0.063)\end{array}$ \\
\hline Bandwidth $=b / 2$ & $\begin{array}{c}0.566 * * * \\
(0.075)\end{array}$ & $\begin{array}{c}-0.171 * * * \\
(0.056)\end{array}$ & $\begin{array}{l}-0.005 \\
(0.014)\end{array}$ & $\begin{array}{l}-0.145 \\
(0.097)\end{array}$ & $\begin{array}{l}-0.128 \\
(0.125)\end{array}$ & $\begin{array}{l}0.303 * \\
(0.167)\end{array}$ & $\begin{array}{c}-0.234^{* *} \\
(0.095)\end{array}$ \\
\hline Bandwidth $=3 \mathrm{~b} / 2$ & $\begin{array}{c}0.421 * * * \\
(0.063)\end{array}$ & $\begin{array}{c}-0.071 * * * \\
(0.025)\end{array}$ & $\begin{array}{l}-0.015 \\
(0.010)\end{array}$ & $\begin{array}{c}-0.077 * * * \\
(0.021)\end{array}$ & $\begin{array}{c}-0.120 * * \\
(0.047)\end{array}$ & $\begin{array}{c}-0.101 * * * \\
(0.031)\end{array}$ & $\begin{array}{c}-0.209 * * * \\
(0.061)\end{array}$ \\
\hline Bandwidth $=2 \mathrm{~b}$ & $\begin{array}{c}0.422 * * * \\
(0.075)\end{array}$ & $\begin{array}{c}-0.067 * * * \\
(0.020)\end{array}$ & $\begin{array}{c}-0.017 * \\
(0.009)\end{array}$ & $\begin{array}{c}-0.083 * * * \\
(0.019)\end{array}$ & $\begin{array}{c}-0.122 * * * \\
(0.043)\end{array}$ & $\begin{array}{c}-0.098^{* * *} \\
(0.029)\end{array}$ & $\begin{array}{c}-0.209 * * * \\
(0.061)\end{array}$ \\
\hline Optimal Bandwidth (b) & 0.866 & 0.689 & 1.078 & 0.880 & 1.310 & 0.951 & 1.294 \\
\hline \multicolumn{8}{|l|}{ B) CCFT Bandwidths } \\
\hline Conventional & $\begin{array}{c}0.404 * * * \\
(0.000)\end{array}$ & $\begin{array}{c}-0.051 * * * \\
(0.000)\end{array}$ & $\begin{array}{c}-0.006 * * * \\
(0.002)\end{array}$ & $\begin{array}{c}-0.058 * * * \\
(0.000)\end{array}$ & $\begin{array}{c}-0.129 * * * \\
(0.017)\end{array}$ & $\begin{array}{l}-- \\
--\end{array}$ & $\begin{array}{c}-0.224 * * \\
(0.093)\end{array}$ \\
\hline Bias-corrected & $\begin{array}{c}0.475 * * * \\
(0.000)\end{array}$ & $\begin{array}{c}-0.085^{* * *} \\
(0.000)\end{array}$ & $\begin{array}{l}-0.004 * \\
(0.002)\end{array}$ & $\begin{array}{c}-0.075^{* * *} \\
(0.000)\end{array}$ & $\begin{array}{c}-0.135^{* * * *} \\
(0.017)\end{array}$ & $\begin{array}{l}-- \\
--\end{array}$ & $\begin{array}{l}-0.155^{*} \\
(0.093)\end{array}$ \\
\hline Robust & $\begin{array}{l}0.475^{*} \\
(0.280)\end{array}$ & $\begin{array}{c}-0.085 * * * \\
(0.021)\end{array}$ & $\begin{array}{c}-0.004 * \\
(0.002)\end{array}$ & $\begin{array}{c}-0.075 * * * \\
(0.021)\end{array}$ & $\begin{array}{c}-0.135^{* * *} \\
(0.027)\end{array}$ & $\begin{array}{l}-- \\
--\end{array}$ & $\begin{array}{l}-0.155 \\
(0.103)\end{array}$ \\
\hline BW loc. poly. & 0.196 & 0.194 & 0.689 & 0.211 & 1.490 & -- & 0.250 \\
\hline BW bias & 0.513 & 0.638 & 1.736 & 0.664 & 1.906 & -- & 0.733 \\
\hline
\end{tabular}

Notes: The data come from the rounds three and four of the Comprehensive Vulnerability Monitoring Exercise (CVME) of Turkey. The dependent variable in column (2) is the residual of beneficiary status after regressing it on the dummy variable for ESSN program eligibility via any of the five other eligibility criteria (single women, single parents with at least one child, elderly with no other adult in the household, families with at least four children, families with at least one disabled person with a report). The dependent variables in columns (3) to (8) are the residuals after regressing the dependent variable in column headings on dummies for the number of boys in columns (3) and (6), for the number of girls in colums (4) and (7), and for the number of children in coumns (5) and (8). Each cell comes from a separate regression. The number of observations is 2,681 in all regressions. In panel (A), local polynomial approach with Imbens-Kalyanaraman (IK) optimal bandwidths are used, which runs kernel regression models on both sides of the cutoff. In addition to the estimates with the optimal IK bandwidths, estimates with alternative bandwidths are provided. In panel (B), local polynomial approach to RDD of CCFT is used. In this method, MSE-optimal bandwidths that are set to be equal on both sides of the cutoff are taken. The order of local polynomial is one and the order of bias is two. In both panels, a triangular kernel is used. Clustering is done at the level of dependency ratio. Column (7) in panel (B) is empty due to convergence problems. Statistically significant: *** 1 percent level; ** 5 percent level, $* 10$ percent level. 
Table C3. The Effect of Dependency-Ratio Criterion on Share of Children Working and Share of Children not in School - Local Polynomial Approach with Baseline Variables

\begin{tabular}{|c|c|c|c|c|c|c|c|}
\hline$(1)$ & (2) & (3) & (4) & $(5)$ & (6) & (7) & $(8)$ \\
\hline & Beneficiary & $\begin{array}{c}\text { Share of } \\
\text { boys } \\
\text { working }\end{array}$ & $\begin{array}{c}\text { Share of } \\
\text { girls } \\
\text { working }\end{array}$ & $\begin{array}{l}\text { Share of } \\
\text { children } \\
\text { working }\end{array}$ & $\begin{array}{c}\text { Share of } \\
\text { boys not in } \\
\text { school }\end{array}$ & $\begin{array}{c}\text { Share of } \\
\text { girls not in } \\
\text { school }\end{array}$ & $\begin{array}{c}\text { Share of } \\
\text { children not } \\
\text { in school }\end{array}$ \\
\hline \multicolumn{8}{|l|}{ A) IK Bandwidths } \\
\hline Bandwidth $=b$ & $\begin{array}{c}0.331 * * * \\
(0.066)\end{array}$ & $\begin{array}{l}-0.049 \\
(0.031)\end{array}$ & $\begin{array}{l}-0.007 \\
(0.012)\end{array}$ & $\begin{array}{c}-0.035^{* * *} \\
(0.011)\end{array}$ & $\begin{array}{c}-0.067 * * * \\
(0.021)\end{array}$ & $\begin{array}{c}-0.063^{* *} \\
(0.027)\end{array}$ & $\begin{array}{c}-0.074 * * * \\
(0.022)\end{array}$ \\
\hline Bandwidth $=b / 2$ & $\begin{array}{c}0.550 * * * \\
(0.089)\end{array}$ & $\begin{array}{l}-0.059 \\
(0.081)\end{array}$ & $\begin{array}{l}-0.043 \\
(0.030)\end{array}$ & $\begin{array}{c}-0.022 * * \\
(0.010)\end{array}$ & $\begin{array}{c}-0.093 * * \\
(0.045)\end{array}$ & $\begin{array}{c}0.073 \\
(0.097)\end{array}$ & $\begin{array}{c}-0.097 * * \\
(0.046)\end{array}$ \\
\hline Bandwidth $=3 \mathrm{~b} / 2$ & $\begin{array}{c}0.410^{* * *} \\
(0.082)\end{array}$ & $\begin{array}{c}-0.041^{* * *} \\
(0.016)\end{array}$ & $\begin{array}{l}-0.001 \\
(0.010)\end{array}$ & $\begin{array}{c}-0.046^{* * *} \\
(0.010)\end{array}$ & $\begin{array}{c}-0.070^{* * *} \\
(0.020)\end{array}$ & $\begin{array}{c}-0.056^{* * *} \\
(0.015)\end{array}$ & $\begin{array}{c}-0.086^{* * *} \\
(0.023)\end{array}$ \\
\hline Bandwidth $=2 b$ & $\begin{array}{c}0.418^{* * * *} \\
(0.083)\end{array}$ & $\begin{array}{c}-0.051 * * * \\
(0.015)\end{array}$ & $\begin{array}{c}-0.012 * * * \\
(0.004)\end{array}$ & $\begin{array}{c}-0.046^{* * *} \\
(0.009)\end{array}$ & $\begin{array}{c}-0.077 * * * \\
(0.018)\end{array}$ & $\begin{array}{c}-0.058^{* * *} \\
(0.012)\end{array}$ & $\begin{array}{c}-0.092 * * * \\
(0.021)\end{array}$ \\
\hline Optimal Bandwidth (b) & 0.680 & 0.714 & 0.597 & 1.094 & 1.236 & 0.998 & 1.279 \\
\hline \multicolumn{8}{|l|}{ B) CCFT Bandwidths } \\
\hline Conventional & $\begin{array}{c}0.404 * * * \\
(0.000)\end{array}$ & $\begin{array}{c}-0.037 * * * \\
(0.009)\end{array}$ & $\begin{array}{l}-- \\
--\end{array}$ & $\begin{array}{c}-0.044 * * \\
(0.021)\end{array}$ & $\begin{array}{c}-0.077 * * * \\
(0.011)\end{array}$ & $\begin{array}{c}-0.069^{* * *} \\
(0.006)\end{array}$ & $\begin{array}{c}-0.095^{* * *} \\
(0.006)\end{array}$ \\
\hline Bias-corrected & $\begin{array}{c}0.394 * * * \\
(0.000)\end{array}$ & $\begin{array}{c}-0.035^{* * *} \\
(0.009)\end{array}$ & $\begin{array}{l}-- \\
--\end{array}$ & $\begin{array}{l}-0.040^{*} \\
(0.021)\end{array}$ & $\begin{array}{c}-0.087 * * * \\
(0.011)\end{array}$ & $\begin{array}{c}-0.066^{* * *} \\
(0.006)\end{array}$ & $\begin{array}{c}-0.101 * * * \\
(0.006)\end{array}$ \\
\hline Robust & $\begin{array}{c}0.394 * * * \\
(0.001)\end{array}$ & $\begin{array}{c}-0.035^{* * *} \\
(0.010)\end{array}$ & $\begin{array}{l}-- \\
--\end{array}$ & $\begin{array}{l}-0.040^{*} \\
(0.021)\end{array}$ & $\begin{array}{c}-0.087 * * * \\
(0.013)\end{array}$ & $\begin{array}{c}-0.066 * * * \\
(0.007)\end{array}$ & $\begin{array}{c}-0.101 * * * \\
(0.009)\end{array}$ \\
\hline $\begin{array}{l}\text { BW loc. poly. } \\
\text { BW bias }\end{array}$ & $\begin{array}{l}0.208 \\
0.999\end{array}$ & $\begin{array}{l}0.668 \\
0.993\end{array}$ & $\begin{array}{l}-- \\
--\end{array}$ & $\begin{array}{l}0.381 \\
1.086\end{array}$ & $\begin{array}{l}0.739 \\
1.238\end{array}$ & $\begin{array}{l}0.619 \\
1.365\end{array}$ & $\begin{array}{l}0.920 \\
1.224\end{array}$ \\
\hline
\end{tabular}

Notes: The data come from the rounds three and four of the Comprehensive Vulnerability Monitoring Exercise (CVME) of Turkey. The dependent variable in column (2) is the residual of beneficiary status after regressing it on the dummy variable for ESSN program eligibility via any of the five other eligibility criteria (single women, single parents with at least one child, elderly with no other adult in the household, families with at least four children, families with at least one disabled person with a report). The dependent variables in columns (3) to (8) are the residuals after regressing the dependent variable in column headings on dummies for the number of boys in columns (3) and (6), for the number of girls in colums (4) and (7), and for the number of children in coumns (5) and (8). Each cell comes from a separate regression. The number of observations is 2,681 in all regressions. In panel (A), local polynomial approach with Imbens-Kalyanaraman (IK) optimal bandwidths are used, which runs kernel regression models on both sides of the cutoff. In addition to the estimates with the optimal IK bandwidths, estimates with alternative bandwidths are provided. In panel (B), local polynomial approach to RDD of CCFT is used. In this method, MSE-optimal bandwidths that are set to be equal on both sides of the cutoff are taken. The order of local polynomial is one and the order of bias is two. In both panels, a uniform kernel is used. Clustering is done at the level of dependency ratio. Column (4) in panel (B) is empty due to convergence problems. Statistically significant: *** 1 percent level; ** 5 percent level, * 10 percent level. 
Table C4: The Effect of Beneficiary Status on the Share of Children Working and the Share of Children not in School by Gender - Local Polynomial Approach with IK Optimal Bandwidths

\begin{tabular}{lcccccc}
\hline \multicolumn{1}{c}{$(1)$} & $(2)$ & $(3)$ & $(4)$ & $(5)$ & $(6)$ & $(7)$ \\
\hline & $\begin{array}{c}\text { Share of } \\
\text { boys } \\
\text { working }\end{array}$ & $\begin{array}{c}\text { Share of } \\
\text { girls } \\
\text { working }\end{array}$ & $\begin{array}{c}\text { Share of } \\
\text { children } \\
\text { working }\end{array}$ & $\begin{array}{c}\text { Share of } \\
\text { boys not in } \\
\text { school }\end{array}$ & $\begin{array}{c}\text { Share of } \\
\text { girls not in } \\
\text { school }\end{array}$ & $\begin{array}{c}\text { Share of } \\
\text { children not } \\
\text { in school }\end{array}$ \\
\cline { 2 - 7 } A) 2SLS Estimates & & & & & & \\
\hline Bandwidth = b & 0.691 & 0.040 & $-0.169^{*}$ & -0.301 & -0.334 & -0.306 \\
Bandwidth $=\mathrm{b} / 2$ & $(0.906)$ & $(0.082)$ & $(0.095)$ & $(0.202)$ & $(0.326)$ & $(0.196)$ \\
& -0.306 & $-0.323^{*}$ & 0.117 & $0.505^{* * *}$ & 0.319 & $0.524^{* * *}$ \\
Bandwidth $=3 \mathrm{~b} / 2$ & $(0.416)$ & $(0.170)$ & $(0.096)$ & $(0.157)$ & $(0.470)$ & $(0.150)$ \\
& -0.197 & -0.004 & $-0.151^{* * *}$ & $-0.229^{* *}$ & -0.229 & $-0.280^{* *}$ \\
Bandwidth $=2 \mathrm{~b}$ & $(0.155)$ & $(0.069)$ & $(0.048)$ & $(0.110)$ & $(0.155)$ & $(0.135)$ \\
& -0.210 & -0.055 & $-0.154^{* * *}$ & $-0.257^{* *}$ & $-0.191^{* *}$ & $-0.309^{* *}$ \\
& $(0.128)$ & $(0.037)$ & $(0.049)$ & $(0.115)$ & $(0.094)$ & $(0.140)$
\end{tabular}

B) First-Stage Estimates

\begin{tabular}{lcccccc}
\hline Bandwidth $=\mathrm{b}$ & -0.070 & $-0.185^{* *}$ & 0.207 & $0.223^{*}$ & 0.188 & $0.241^{*}$ \\
& $(0.076)$ & $(0.080)$ & $(0.127)$ & $(0.125)$ & $(0.133)$ & $(0.124)$ \\
Bandwidth $=\mathrm{b} / 2$ & $0.193^{* * *}$ & 0.132 & $-0.185^{* *}$ & $-0.185^{* *}$ & $0.228^{* * *}$ & $-0.185^{* *}$ \\
& $(0.071)$ & $(0.083)$ & $(0.080)$ & $(0.080)$ & $(0.064)$ & $(0.079)$ \\
Bandwidth = 3b/2 & 0.207 & 0.158 & $0.305^{* * *}$ & $0.306^{* * *}$ & $0.243^{* *}$ & $0.306^{* * *}$ \\
& $(0.127)$ & $(0.130)$ & $(0.107)$ & $(0.107)$ & $(0.122)$ & $(0.107)$ \\
Bandwidth = b & $0.243^{* *}$ & $0.223^{*}$ & $0.300^{* * *}$ & $0.300^{* * *}$ & $0.306^{* * *}$ & $0.297^{* * *}$ \\
& $(0.122)$ & $(0.125)$ & $(0.106)$ & $(0.106)$ & $(0.107)$ & $(0.106)$ \\
Observations & & & & & & \\
BW loc. poly. & 2,681 & 2,681 & 2,681 & 2,681 & 2,681 & 2,681 \\
\hline
\end{tabular}

Notes: The data come from the rounds three and four of the Comprehensive Vulnerability Monitoring Exercise (CVME) of Turkey. The dependent variables in columns (2) to (7) are the residuals after regressing the dependent variable in column headings on dummies for the number of boys in columns (2) and (5), for the number of girls in colums (3) and (6), and for the number of children in coumns (4) and (7). Each cell comes from a separate regression. The number of observations is 2,681 in all regressions. Local polynomial approach with Imbens-Kalyanaraman (IK) optimal bandwidths are used, which runs kernel regression models on both sides of the cutoff. In addition to the estimates with the optimal IK bandwidths, estimates with alternative bandwidths are provided. A uniform kernel is used. Clustering is done at the level of dependency ratio. Statistically significant: *** 1 percent level; ** 5 percent level, * 10 percent level. 


\section{APPENDIX D: Robustness Check with Donut-hole RDD}

Table D1: The Effect of Dependency-Ratio (DR) Criterion on Share of Children Working and Share of Children not in School by Gender when DR=1.5 is Excluded

\begin{tabular}{|c|c|c|c|c|c|c|c|c|c|}
\hline$(1)$ & $(2)$ & (3) & (4) & $(5)$ & (6) & (7) & $(8)$ & (9) & $(10)$ \\
\hline & Beneficiary & $\begin{array}{c}\text { Share of } \\
\text { boys } \\
\text { working }\end{array}$ & $\begin{array}{c}\text { Share of } \\
\text { girls } \\
\text { working }\end{array}$ & $\begin{array}{l}\text { Share of } \\
\text { children } \\
\text { working }\end{array}$ & $\begin{array}{c}\text { Share of } \\
\text { boys not in } \\
\text { school }\end{array}$ & $\begin{array}{c}\text { Share of } \\
\text { girls not in } \\
\text { school }\end{array}$ & $\begin{array}{c}\text { Share of } \\
\text { children not } \\
\text { in school }\end{array}$ & No obs. & $\begin{array}{c}\text { No. } \\
\text { cluster }\end{array}$ \\
\hline \multicolumn{10}{|l|}{ A) Baseline } \\
\hline Full Data with Hole $(D R \neq 1.5)$ & $\begin{array}{c}0.171 * * * \\
{[0.044]}\end{array}$ & $\begin{array}{c}-0.056^{* * *} \\
{[0.015]}\end{array}$ & $\begin{array}{c}-0.011^{* *} \\
{[0.005]}\end{array}$ & $\begin{array}{c}-0.043 * * * \\
{[0.012]}\end{array}$ & $\begin{array}{c}-0.068 * * * \\
{[0.024]}\end{array}$ & $\begin{array}{c}-0.053^{* * *} \\
{[0.014]}\end{array}$ & $\begin{array}{c}-0.078^{* * *} \\
{[0.024]}\end{array}$ & 2,307 & 55 \\
\hline $0<=\mathrm{DR}<=4.5 \& \mathrm{DR} \neq 1.5$ & $\begin{array}{c}0.169 * * * \\
{[0.045]}\end{array}$ & $\begin{array}{c}-0.046^{* * *} \\
{[0.013]}\end{array}$ & $\begin{array}{c}-0.011^{* *} \\
{[0.005]}\end{array}$ & $\begin{array}{c}-0.036^{* * *} \\
{[0.012]}\end{array}$ & $\begin{array}{c}-0.073 * * \\
{[0.029]}\end{array}$ & $\begin{array}{c}-0.061 * * * \\
{[0.016]}\end{array}$ & $\begin{array}{c}-0.080^{* * *} \\
{[0.029]}\end{array}$ & 2,215 & 50 \\
\hline $0<=\mathrm{DR}<=3.5 \& \mathrm{DR} \neq 1.5$ & $\begin{array}{c}0.183 * * * \\
{[0.048]}\end{array}$ & $\begin{array}{c}-0.051 * * * \\
{[0.014]}\end{array}$ & $\begin{array}{c}-0.007 \\
{[0.006]}\end{array}$ & $\begin{array}{c}-0.033^{* * * *} \\
{[0.011]}\end{array}$ & $\begin{array}{c}-0.063 * \\
{[0.034]}\end{array}$ & $\begin{array}{c}-0.057 * * * \\
{[0.017]}\end{array}$ & $\begin{array}{c}-0.067 * \\
{[0.033]}\end{array}$ & 2,136 & 47 \\
\hline $0<=\mathrm{DR}<=3.0 \& \mathrm{DR} \neq 1.5$ & $\begin{array}{c}0.206 * * * \\
{[0.047]} \\
\end{array}$ & $\begin{array}{c}-0.042 * * * \\
{[0.015]}\end{array}$ & $\begin{array}{l}-0.011^{*} \\
{[0.006]}\end{array}$ & $\begin{array}{c}-0.030 * * \\
{[0.011]} \\
\end{array}$ & $\begin{array}{c}-0.042 \\
{[0.035]}\end{array}$ & $\begin{array}{c}-0.046^{* *} \\
{[0.017]} \\
\end{array}$ & $\begin{array}{l}-0.051 \\
{[0.035]}\end{array}$ & 2,074 & 44 \\
\hline \multicolumn{10}{|l|}{ B) Full Controls } \\
\hline Full Data with Hole $(\mathrm{DR} \neq 1.5)$ & $\begin{array}{c}0.184 * * * \\
{[0.045]}\end{array}$ & $\begin{array}{c}-0.053 * * * \\
{[0.014]}\end{array}$ & $\begin{array}{l}-0.003 \\
{[0.007]}\end{array}$ & $\begin{array}{c}-0.037 * * * \\
{[0.012]}\end{array}$ & $\begin{array}{c}-0.054 * * \\
{[0.025]}\end{array}$ & $\begin{array}{l}-0.030 \\
{[0.022]}\end{array}$ & $\begin{array}{c}-0.053^{* *} \\
{[0.023]}\end{array}$ & 2,307 & 55 \\
\hline $0<=\mathrm{DR}<=4.5 \& \mathrm{DR} \neq 1.5$ & $\begin{array}{c}0.190^{* * *} \\
{[0.050]}\end{array}$ & $\begin{array}{c}-0.047 * * * \\
{[0.013]}\end{array}$ & $\begin{array}{l}-0.004 \\
{[0.007]}\end{array}$ & $\begin{array}{c}-0.034^{* * * *} \\
{[0.012]}\end{array}$ & $\begin{array}{l}-0.057^{*} \\
{[0.029]}\end{array}$ & $\begin{array}{l}-0.035 \\
{[0.025]}\end{array}$ & $\begin{array}{l}-0.055^{*} \\
{[0.029]}\end{array}$ & 2,215 & 50 \\
\hline $0<=\mathrm{DR}<=3.5 \& \mathrm{DR} \neq 1.5$ & $\begin{array}{c}0.218^{* * *} \\
{[0.050]}\end{array}$ & $\begin{array}{c}-0.053 * * * \\
{[0.014]}\end{array}$ & $\begin{array}{c}-0.003 \\
{[0.007]}\end{array}$ & $\begin{array}{c}-0.036^{* * * *} \\
{[0.012]}\end{array}$ & $\begin{array}{l}-0.055 \\
{[0.035]}\end{array}$ & $\begin{array}{c}-0.039 \\
{[0.026]}\end{array}$ & $\begin{array}{c}-0.053 \\
{[0.033]}\end{array}$ & 2,136 & 47 \\
\hline $0<=\mathrm{DR}<=3.0 \& \mathrm{DR} \neq 1.5$ & $\begin{array}{c}0.225 * * * \\
{[0.052]}\end{array}$ & $\begin{array}{c}-0.046^{* * *} \\
{[0.016]}\end{array}$ & $\begin{array}{l}-0.008 \\
{[0.006]}\end{array}$ & $\begin{array}{c}-0.032 * * \\
{[0.012]}\end{array}$ & $\begin{array}{l}-0.036 \\
{[0.035]}\end{array}$ & $\begin{array}{c}-0.030 \\
{[0.027]}\end{array}$ & $\begin{array}{l}-0.039 \\
{[0.034]}\end{array}$ & 2,074 & 44 \\
\hline
\end{tabular}

Notes: "DR" stands for dependency ratio. The data come from the rounds three and four of the Comprehensive Vulnerability Monitoring Exercise (CVME) of Turkey. The sample is restricted to various bandwidths around the cutoff (except for the donut hole at dependency ratio=1.5) as given in column (1). The dependent variable is given in column headings (2) to (8). Each cell comes from a separate regression. All regressions include a control for the policy dummy and split linear polynomials around the cutoff in the running variable (dependency ratio). The baseline specification in panel (A) includes no other controls. The full specification, in panel (B), also includes household characteristics including number of children below age six, number of prime adults in the household, dummies for household head's sex, education (illiterate, literate, primary/intermediate, secondary, technical, university), occupation before arrival (management/highly skilled, skilled worker, semi-skilled worker, unskilled worker, retired, other), nationality (Afghan, Iraqi, Syrian, other), time of arrival (less than 6 months, 6 months- 1 year, 1 year - 3 years, more than 3 years), 12 NUTS-1 level regions in all columns, and a dummy variable for ESSN eligibility status based on any other criteria (single women, single parents with at least one child, elderly with no other adult in the household, families with at least four children, families with at least one disabled person with a report). Clustering is done at the level of dependency ratio. Statistically significant: *** 1 percent level; ** 5 percent level, ${ }^{*} 10$ percent level. 
Table D2: The Effect of Dependency-Ratio Criterion on Shares of Children Working and not in School by Gender, where $1.25<=$ Dependency Ratio $<=1.75$ is Dropped

\begin{tabular}{|c|c|c|c|c|c|c|c|c|c|}
\hline (1) & (2) & (3) & (4) & (5) & (6) & (7) & $(8)$ & (9) & $(10)$ \\
\hline & Beneficiary & $\begin{array}{c}\text { Share of } \\
\text { boys } \\
\text { working }\end{array}$ & $\begin{array}{c}\text { Share of } \\
\text { girls } \\
\text { working }\end{array}$ & $\begin{array}{l}\text { Share of } \\
\text { children } \\
\text { working }\end{array}$ & $\begin{array}{c}\text { Share of } \\
\text { boys not in } \\
\text { school }\end{array}$ & $\begin{array}{c}\text { Share of } \\
\text { girls not in } \\
\text { school }\end{array}$ & $\begin{array}{c}\text { Share of } \\
\text { children not } \\
\text { in school }\end{array}$ & No obs. & $\begin{array}{c}\text { No. } \\
\text { cluster }\end{array}$ \\
\hline \multicolumn{10}{|l|}{ A) Baseline } \\
\hline $0<=\mathrm{DR}<1.25 \& 1.75<\mathrm{DR}$ & $\begin{array}{c}0.218 * * * \\
{[0.027]}\end{array}$ & $\begin{array}{c}-0.064 * * * \\
{[0.016]}\end{array}$ & $\begin{array}{c}-0.014 * * * \\
{[0.005]}\end{array}$ & $\begin{array}{c}-0.054 * * * \\
{[0.011]}\end{array}$ & $\begin{array}{c}-0.069 * * * \\
{[0.024]}\end{array}$ & $\begin{array}{c}-0.057 * * * \\
{[0.014]}\end{array}$ & $\begin{array}{c}-0.090 * * * \\
{[0.022]}\end{array}$ & 2,146 & 48 \\
\hline $0<=\mathrm{DR}<1.25 \& 1.75<\mathrm{DR}<=4.5$ & $\begin{array}{c}0.216^{* * * *} \\
{[0.029]}\end{array}$ & $\begin{array}{c}-0.056^{* * *} \\
{[0.015]}\end{array}$ & $\begin{array}{c}-0.015^{* * *} \\
{[0.005]}\end{array}$ & $\begin{array}{c}-0.049^{* * * *} \\
{[0.011]}\end{array}$ & $\begin{array}{c}-0.071^{* *} \\
{[0.026]}\end{array}$ & $\begin{array}{c}-0.066^{* * *} \\
{[0.016]}\end{array}$ & $\begin{array}{c}-0.090 * * * \\
{[0.027]}\end{array}$ & 2,054 & 43 \\
\hline $0<=\mathrm{DR}<1.25 \& 1.75<\mathrm{DR}<=3.5$ & $\begin{array}{c}0.233 * * * \\
{[0.033]}\end{array}$ & $\begin{array}{c}-0.066^{* * *} \\
{[0.017]}\end{array}$ & $\begin{array}{l}-0.011^{*} \\
{[0.006]}\end{array}$ & $\begin{array}{c}-0.044 * * * \\
{[0.010]}\end{array}$ & $\begin{array}{l}-0.058^{*} \\
{[0.029]}\end{array}$ & $\begin{array}{c}-0.061 * * * \\
{[0.017]}\end{array}$ & $\begin{array}{c}-0.067^{* *} \\
{[0.026]}\end{array}$ & 1,975 & 40 \\
\hline $0<=\mathrm{DR}<1.25 \& 1.75<\mathrm{DR}<=3.0$ & $\begin{array}{c}0.264 * * * \\
{[0.025]} \\
\end{array}$ & $\begin{array}{c}-0.058^{* * *} \\
{[0.016]} \\
\end{array}$ & $\begin{array}{c}-0.016^{* * *} \\
{[0.004]} \\
\end{array}$ & $\begin{array}{c}-0.042 * * * \\
{[0.011]} \\
\end{array}$ & $\begin{array}{l}-0.026 \\
{[0.017]}\end{array}$ & $\begin{array}{c}-0.045^{* * *} \\
{[0.012]} \\
\end{array}$ & $\begin{array}{l}-0.044 * \\
{[0.023]}\end{array}$ & 1,913 & 37 \\
\hline \multicolumn{10}{|l|}{ B) Full Controls } \\
\hline $0<=\mathrm{DR}<1.25 \& 1.75<\mathrm{DR}$ & $\begin{array}{c}0.235 * * * \\
{[0.035]}\end{array}$ & $\begin{array}{c}-0.070^{* * *} \\
{[0.016]}\end{array}$ & $\begin{array}{c}-0.002 \\
{[0.007]}\end{array}$ & $\begin{array}{c}-0.051 * * * \\
{[0.012]}\end{array}$ & $\begin{array}{c}-0.055^{* *} \\
{[0.023]}\end{array}$ & $\begin{array}{l}-0.025 \\
{[0.022]}\end{array}$ & $\begin{array}{c}-0.055^{* *} \\
{[0.024]}\end{array}$ & 2,146 & 48 \\
\hline $0<=\mathrm{DR}<1.25 \& 1.75<\mathrm{DR}<=4.5$ & $\begin{array}{c}0.245 * * * \\
{[0.039]}\end{array}$ & $\begin{array}{c}-0.065^{* * *} * \\
{[0.015]}\end{array}$ & $\begin{array}{c}-0.004 \\
{[0.008]}\end{array}$ & $\begin{array}{c}-0.049 * * * \\
{[0.011]}\end{array}$ & $\begin{array}{c}-0.052 * * \\
{[0.024]}\end{array}$ & $\begin{array}{l}-0.028 \\
{[0.025]}\end{array}$ & $\begin{array}{l}-0.054 * \\
{[0.028]}\end{array}$ & 2,054 & 43 \\
\hline $0<=\mathrm{DR}<1.25 \& 1.75<\mathrm{DR}<=3.5$ & $\begin{array}{c}0.284 * * * \\
{[0.032]}\end{array}$ & $\begin{array}{c}-0.074 * * * \\
{[0.016]}\end{array}$ & $\begin{array}{c}-0.003 \\
{[0.008]}\end{array}$ & $\begin{array}{c}-0.052 * * * \\
{[0.010]}\end{array}$ & $\begin{array}{l}-0.048^{*} \\
{[0.028]}\end{array}$ & $\begin{array}{c}-0.034 \\
{[0.027]}\end{array}$ & $\begin{array}{c}-0.047 \\
{[0.028]}\end{array}$ & 1,975 & 40 \\
\hline $0<=\mathrm{DR}<1.25 \& 1.75<\mathrm{DR}<=3.0$ & $\begin{array}{c}0.300^{* * * *} \\
{[0.024]}\end{array}$ & $\begin{array}{c}-0.069 * * * \\
{[0.017]}\end{array}$ & $\begin{array}{c}-0.009 \\
{[0.006]}\end{array}$ & $\begin{array}{c}-0.050 * * * \\
{[0.010]}\end{array}$ & $\begin{array}{l}-0.019 \\
{[0.015]}\end{array}$ & $\begin{array}{l}-0.020 \\
{[0.022]}\end{array}$ & $\begin{array}{l}-0.026 \\
{[0.020]}\end{array}$ & 1,913 & 37 \\
\hline
\end{tabular}

Notes: "DR" stands for dependency ratio. The data come from the rounds three and four of the Comprehensive Vulnerability Monitoring Exercise (CVME) of Turkey. The sample is restricted to various bandwidths around the cutoff (except for the donut hole around dependency ratio=1.5) as given in column (1). The dependent variable is given in column headings (2) to (8). Each cell comes from a separate regression. All regressions include a control for the policy dummy and split linear polynomials around the cutoff in the running variable (dependency ratio). The baseline specification in panel (A) includes no other controls. The full specification, in panel (B), also includes household characteristics including number of children below age six, number of prime adults in the household, dummies for household head's sex, education (illiterate, literate, primary/intermediate, secondary, technical, university), occupation before arrival (management/highly skilled, skilled worker, semi-skilled worker, unskilled worker, retired, other), nationality (Afghan, Iraqi, Syrian, other), time of arrival (less than 6 months, 6 months- 1 year, 1 year - 3 years, more than 3 years), 12 NUTS-1 level regions in all columns, and a dummy variable for ESSN eligibility status based on any other criteria (single women, single parents with at least one child, elderly with no other adult in the household, families with at least four children, families with at least one disabled person with a report). Clustering is done at the level of dependency ratio. Statistically significant: *** 1 percent level; ** 5 percent level, $* 10$ percent level. 


\section{Appendix E - Propensity Score Matching Estimation}

This appendix provides details on the methodology and results using Propensity score matching as a robustness check. When using PSM, we follow closely the specification employed for our main identification strategy using RDD, with some notable differences. With PSM, we match beneficiary households to non-beneficiary applicant households. Non-applicants are excluded from the estimation because they may differ from applicants in non-observable characteristicsthe fact that they are not applying to the program may be driven by non-observable characteristics. Results are similar when non-applicants are included in the sample. We match households based on the set of control variables which we use in our main RDD strategy. ${ }^{45}$ We use the PSM estimator implemented in Stata as per Leuven and Sianesi (2014) and show results using the default option (single nearest-neighbor, with replacement). Results are robust to alternative specifications using a different matching algorithm, different set of covariates, matching without replacement, or matching in the sample within the bandwidth of dependency ratio between 0 and 3 (similar to one of the samples used in our RDD approach).

Figure F1 suggests that the matching is efficient at reducing the gap in observable characteristics between beneficiaries and non-beneficiary applicants. As expected, the initial difference is particularly large in terms of eligibility criteria (including household demographic composition), but the difference after matching is small. Given these initial differences, treated and non-treated households differ in their propensity score, but common support is still found across the range of scores for treated and non-treated households (Figure F2).

Results from Table F1 are consistent with our main results using RDD. Specifically, we find a significant decrease in the number and share of children working and not going to school for both genders. In our baseline PSM specification, the effect on girls is stronger in terms of number of girls working and number of girls not going to school. The reduction in the share of girls working or not going to school is similar across gender. The total effect on the number of children working decreases by 0.116 while the average number of children working in the control group is 0.167

\footnotetext{
${ }^{45}$ Our concern in the choice of matching variables in particular, and with propensity score matching in general, is that results may be affected by the arbitrary decisions made in the chosen specification (Caliendo and Kopeinig, 2008). For this reason, we use as matching variables the set of variables previously chosen as controls for the RDD specification. As an alternative, we use the set of matching variables used by Ozler et al. (2020) which are available in our dataset and less likely to be affected by program participation. Results are similar.
} 
( $69 \%$ reduction). The share of children working decreases by 0.0426 while the average share of children working is 0.079 in the control group (54\% reduction). A similar magnitude is found on the number of children not going to school: a decrease by 0.24 children for an average value of 0.454 in the control group (53\% reduction). In share of children working, we find a decrease of 0.0655 for a baseline value of 0.214 ( $31 \%$ reduction). 
Figure E1: Reduction Bias, Propensity Score Matching

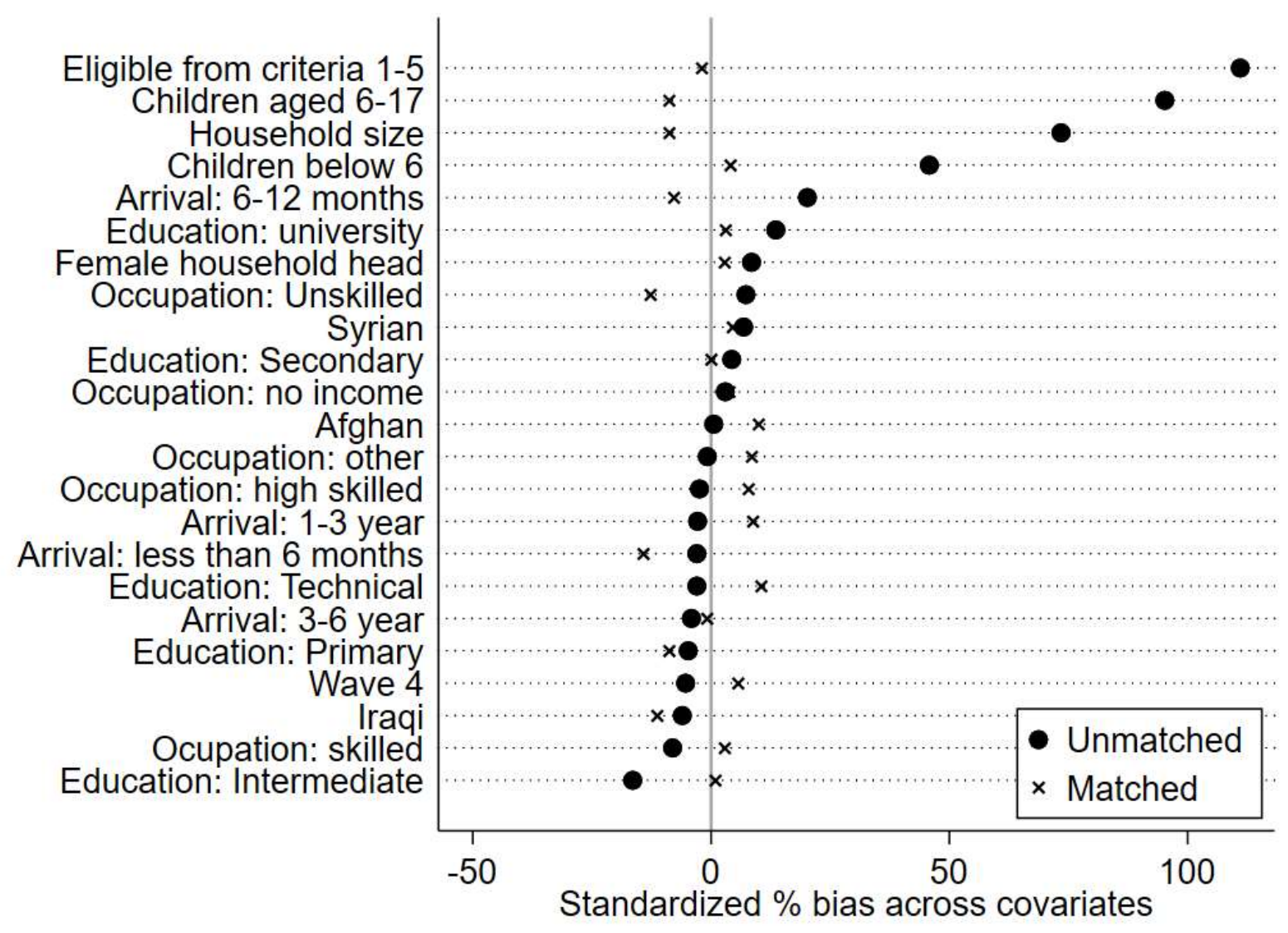


Figure E2: Common Support

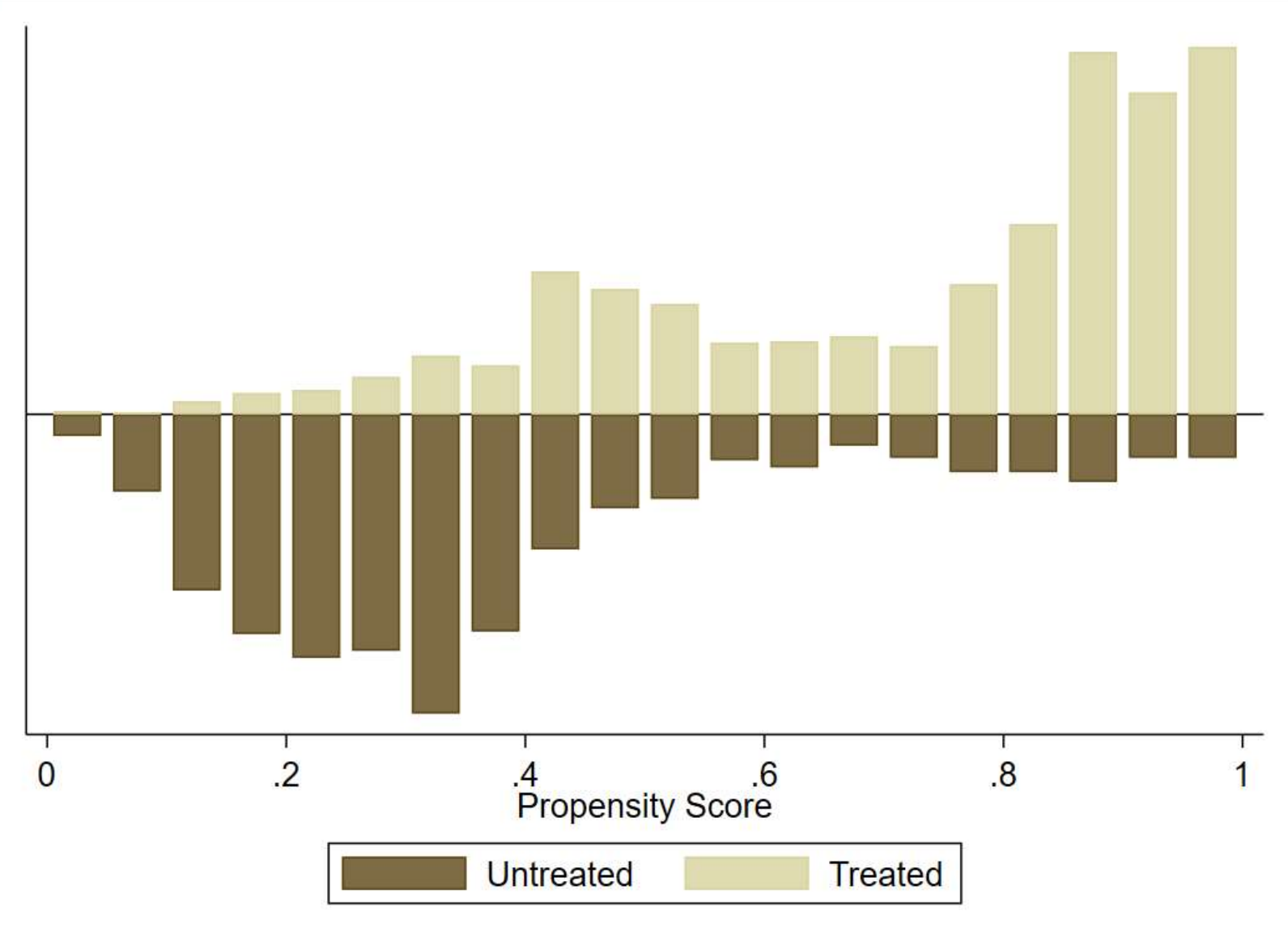


Table E1: Policy effect on number of children working and not in school, full controls

\begin{tabular}{lcccccc}
\hline & $\begin{array}{c}(1) \\
\text { Number of } \\
\text { boys working }\end{array}$ & $\begin{array}{c}(2) \\
\text { Number of } \\
\text { girls working }\end{array}$ & $\begin{array}{c}(3) \\
\text { Number of } \\
\text { children } \\
\text { working }\end{array}$ & $\begin{array}{c}\text { Number of } \\
\text { boys not in } \\
\text { school }\end{array}$ & $\begin{array}{c}\text { Number of } \\
\text { girls not in } \\
\text { school }\end{array}$ & $\begin{array}{c}\text { Number of } \\
\text { children not in } \\
\text { school }\end{array}$ \\
\hline Beneficiary & $-0.0430^{* *}$ & $-0.0732^{* * *}$ & $-0.116^{* * *}$ & $-0.0676^{* * *}$ & $-0.172^{* * *}$ & $-0.240^{* * *}$ \\
$(-2.39)$ & $(-5.97)$ & $(-5.37)$ & $(-2.61)$ & $(-5.97)$ & $2762)$ \\
\hline Observations & 2768 & 2768 & 2768 & 2768 & 2768 & 2768 \\
Control Mean & 0.124 & 0.043 & 0.167 & 0.233 & 0.221 & 0.454 \\
\hline
\end{tabular}

$t$ statistics in parentheses

Notes: The data comes from CVME3 and CVME4. Estimation conducted using Propensity Score Matching. Beneficiary households are matched to non-beneficiary applicants based on observable characteristics. The set of matching variables includes: the number of total household members, the number of children below age six, the number of children aged 6-17, dummies for household head's sex, education levels, occupation before arrival, nationality, time of arrival, and NUTS-1 level regions. The same set of variables is used as controls. Control Mean indicates variable average in the sample of non-beneficiary applicants. $" p<0.10,{ }^{* *} p<0.05,{ }^{* * *} p<0.01$

Table E2: Policy effect on shares of children working and not in school, full controls

\begin{tabular}{|c|c|c|c|c|c|c|}
\hline & $\begin{array}{c}\text { (1) } \\
\text { Share of boys } \\
\text { working }\end{array}$ & $\begin{array}{c}\text { (2) } \\
\text { Share of girls } \\
\text { working }\end{array}$ & $\begin{array}{l}\text { (3) } \\
\text { Share of } \\
\text { children } \\
\text { working }\end{array}$ & $\begin{array}{c}\text { (4) } \\
\text { Share of boys } \\
\text { not in school }\end{array}$ & $\begin{array}{l}\text { (5) } \\
\text { Share of girls } \\
\text { not in school }\end{array}$ & $\begin{array}{c}(6) \\
\text { Share of } \\
\text { children not in } \\
\text { school }\end{array}$ \\
\hline Beneficiary & $\begin{array}{c}-0.0356^{* * *} \\
(-3.71)\end{array}$ & $\begin{array}{c}-0.0344^{* * *} \\
(-6.04)\end{array}$ & $\begin{array}{c}-0.0426^{* * * *} \\
(-5.80)\end{array}$ & $\begin{array}{c}-0.0551^{* * *} \\
(-4.04)\end{array}$ & $\begin{array}{c}-0.0598^{* * *} \\
(-4.64)\end{array}$ & $\begin{array}{c}-0.0655^{* * *} \\
(-5.11)\end{array}$ \\
\hline Observations & 2768 & 2768 & 2768 & 2768 & 2768 & 2768 \\
\hline Control Mean & 0.083 & 0.021 & 0.079 & 0.159 & 0.135 & 0.214 \\
\hline
\end{tabular}

$t$ statistics in parentheses

Notes: The data comes from CVME3 and CVME4. Estimation conducted using Propensity Score Matching. Beneficiary households are matched to non-beneficiary applicants based on observable characteristics. The set of matching variables includes: the number of total household members, the number of children below age six, the number of children aged 6-17, dummies for household head's sex, education levels, occupation before arrival, nationality, time of arrival, and NUTS-1 level regions. The same set of variables is used as controls. Control Mean indicates variable average in the sample of non-beneficiary applicants.

${ }^{*} p<0.10,{ }^{* *} p<0.05,{ }^{* * *} p<0.01$ 


\section{APPENDIX F: Analysis with the PDM Data}

Table F1: The Effect of Dependency-Ratio Criterion on Beneficiary Status, on Coping Strategies, and on Number of Children not in School using the PDM4 dataset

\begin{tabular}{|c|c|c|c|c|c|c|}
\hline (1) & (2) & (3) & $(4)$ & (5) & (6) & (7) \\
\hline & $\begin{array}{c}\text { Beneficiary } \\
\text { status }\end{array}$ & $\begin{array}{c}\text { Coping } \\
\text { strategy: child } \\
\text { labor (30 days) }\end{array}$ & $\begin{array}{l}\text { Coping strategy: } \\
\text { removed from } \\
\text { school ( } 30 \text { days) }\end{array}$ & $\begin{array}{c}\text { Has one } \\
\text { child not at } \\
\text { school }(=1)\end{array}$ & $\begin{array}{l}\text { Number of } \\
\text { children not } \\
\text { at school }\end{array}$ & $\begin{array}{l}\text { No } \\
\text { obs. }\end{array}$ \\
\hline Full Data & $\begin{array}{l}0.281^{* *} \\
{[0.106]}\end{array}$ & $\begin{array}{c}-0.066^{* * *} * \\
{[0.010]}\end{array}$ & $\begin{array}{l}-0.035^{*} \\
{[0.020]}\end{array}$ & $\begin{array}{c}-0.093 * * * \\
{[0.023]}\end{array}$ & $\begin{array}{c}-0.180 * * * \\
{[0.045]}\end{array}$ & 6,184 \\
\hline $0<=\mathrm{DR}<=4.5$ & $\begin{array}{c}0.290 * * * \\
{[0.109]}\end{array}$ & $\begin{array}{c}-0.059^{* * *} \\
{[0.011]}\end{array}$ & $\begin{array}{l}-0.033 \\
{[0.020]}\end{array}$ & $\begin{array}{c}-0.089 * * * \\
{[0.024]}\end{array}$ & $\begin{array}{c}-0.170 * * * \\
{[0.047]}\end{array}$ & 6,137 \\
\hline $0<=\mathrm{DR}<=3.5$ & $\begin{array}{c}0.304 * * * \\
{[0.110]}\end{array}$ & $\begin{array}{c}-0.056^{* * *} * \\
{[0.010]}\end{array}$ & $\begin{array}{c}-0.029 \\
{[0.020]}\end{array}$ & $\begin{array}{c}-0.083 * * * \\
{[0.023]}\end{array}$ & $\begin{array}{c}-0.151^{* * *} \\
{[0.044]}\end{array}$ & 6,023 \\
\hline $0<=\mathrm{DR}<=3.0$ & $\begin{array}{c}0.315 * * * \\
{[0.110]}\end{array}$ & $\begin{array}{c}-0.055^{* * * *} \\
{[0.010]}\end{array}$ & $\begin{array}{c}-0.031 \\
{[0.021]}\end{array}$ & $\begin{array}{c}-0.080 * * * \\
{[0.024]}\end{array}$ & $\begin{array}{c}-0.150 * * * \\
{[0.046]}\end{array}$ & 5,935 \\
\hline $0.5<=\mathrm{DR}<=2.5$ & $\begin{array}{c}0.290 * * \\
{[0.140]}\end{array}$ & $\begin{array}{c}-0.045^{* * *} \\
{[0.011]}\end{array}$ & $\begin{array}{c}-0.032 \\
{[0.023]}\end{array}$ & $\begin{array}{c}-0.03 \\
{[0.034]}\end{array}$ & $\begin{array}{c}-0.08 \\
{[0.059]}\end{array}$ & 5,117 \\
\hline
\end{tabular}

Notes: "DR" stands for dependency ratio. The data come from the fourth rounds of the Post-Distribution Monitoring survey (PDM). The sample is restricted to various bandwidths around the cutoff (dependency ratio=1.5) as given in column (1). The dependent variable is given in column headings (2) to (6). Each cell comes from a separate regression. All regressions include a control for the policy dummy, split linear polynomials around the cutoff in the running variable (dependency ratio), a dummy variable for eligibility status via any other channel, household characteristics including the number total household members, the number of children below age six, the number of children aged 6-17, dummies for household head's sex, education (illiterate, literate, primary/intermediate, secondary, technical, university), occupation before arrival (management/highly skilled, skilled worker, unskilled worker, retired, other), nationality (Afghan, Iraqi, Syrian, other), time of arrival (less than 6 months, 6 months- 1 year, 1 year -3 years, more than 3 years, before the conflict started), and 12 NUTS-1 level regions in all columns. Clustering is done at the level of dependency ratio.

$* * * \mathrm{p}<0.01, * * \mathrm{p}<0.05, * \mathrm{p}<0.1$ 
Table F2: The Effect of Beneficiary Status on Coping Strategies, and on Number of Children not in School using the PDM4 dataset

\begin{tabular}{|c|c|c|c|c|c|}
\hline (1) & (2) & (3) & (4) & (5) & (6) \\
\hline & $\begin{array}{c}\text { Coping } \\
\text { strategy: child } \\
\text { labor ( } 30 \text { days) }\end{array}$ & $\begin{array}{l}\text { Coping strategy: } \\
\text { removed from } \\
\text { school ( } 30 \text { days) }\end{array}$ & $\begin{array}{c}\text { Has one } \\
\text { child not at } \\
\text { school }(=1)\end{array}$ & $\begin{array}{c}\text { Number of } \\
\text { children not } \\
\text { at school }\end{array}$ & $\begin{array}{l}\text { No } \\
\text { obs. }\end{array}$ \\
\hline Full Data & $\begin{array}{c}-0.235 * * \\
{[0.107]}\end{array}$ & $\begin{array}{c}-0.125 \\
{[0.115]}\end{array}$ & $\begin{array}{c}-0.331 * * \\
{[0.168]}\end{array}$ & $\begin{array}{c}-0.643 * \\
{[0.346]}\end{array}$ & 6,184 \\
\hline $0<=\mathrm{DR}<=4.5$ & $\begin{array}{c}-0.214 * * \\
{[0.104]}\end{array}$ & $\begin{array}{c}-0.136 \\
{[0.135]}\end{array}$ & $\begin{array}{c}-0.344 * \\
{[0.180]}\end{array}$ & $\begin{array}{l}-0.671 * \\
{[0.373]}\end{array}$ & 6,137 \\
\hline $0<=\mathrm{DR}<=3.5$ & $\begin{array}{c}-0.197 * * \\
{[0.093]}\end{array}$ & $\begin{array}{c}-0.126 \\
{[0.129]}\end{array}$ & $\begin{array}{c}-0.318 * \\
{[0.165]}\end{array}$ & $\begin{array}{l}-0.606 * \\
{[0.336]}\end{array}$ & 6,023 \\
\hline $0<=\mathrm{DR}<=3.0$ & $\begin{array}{c}-0.190 * * \\
{[0.089]}\end{array}$ & $\begin{array}{c}-0.132 \\
{[0.132]}\end{array}$ & $\begin{array}{c}-0.310 * \\
{[0.162]}\end{array}$ & $\begin{array}{c}-0.604 * \\
{[0.336]}\end{array}$ & 5,935 \\
\hline $0.5<=\mathrm{DR}<=2.5$ & $\begin{array}{c}-0.179 \\
{[0.143]}\end{array}$ & $\begin{array}{c}-0.222 \\
{[0.296]}\end{array}$ & $\begin{array}{c}-0.181 \\
{[0.202]}\end{array}$ & $\begin{array}{c}-0.529 \\
{[0.522]}\end{array}$ & 5,117 \\
\hline
\end{tabular}

Notes: "DR" stands for dependency ratio. The data come from the fourth rounds of the Post-Distribution Monitoring survey (PDM). The sample is restricted to various bandwidths around the cutoff (dependency ratio $=1.5$ ) as given in column (1). The dependent variable is given in column headings (2) to (5). Each cell comes from a separate 2 SLS regression, where beneficiary status is instrumented via treatment status in terms of dependency ratio. All regressions include a control for the policy dummy, split linear polynomials around the cutoff in the running variable (dependency ratio), a dummy variable for eligibility status via any other channel, household characteristics including the number total household members, the number of children below age six, the number of children aged 6-17, dummies for household head's sex, education (illiterate, literate, primary/intermediate, secondary, technical, university), occupation before arrival (management/highly skilled, skilled worker, unskilled worker, retired, other), nationality (Afghan, Iraqi, Syrian, other), time of arrival (less than 6 months, 6 months- 1 year, 1 year -3 years, more than 3 years, before the conflict started), and 12 NUTS-1 level regions in all columns. Clustering is done at the level of dependency ratio.

$* * * \mathrm{p}<0.01, * * \mathrm{p}<0.05, * \mathrm{p}<0.1$ 